Prepared in cooperation with the Virginia Department of Transportation

\title{
Peak-Flow Characteristics of Virginia Streams
}

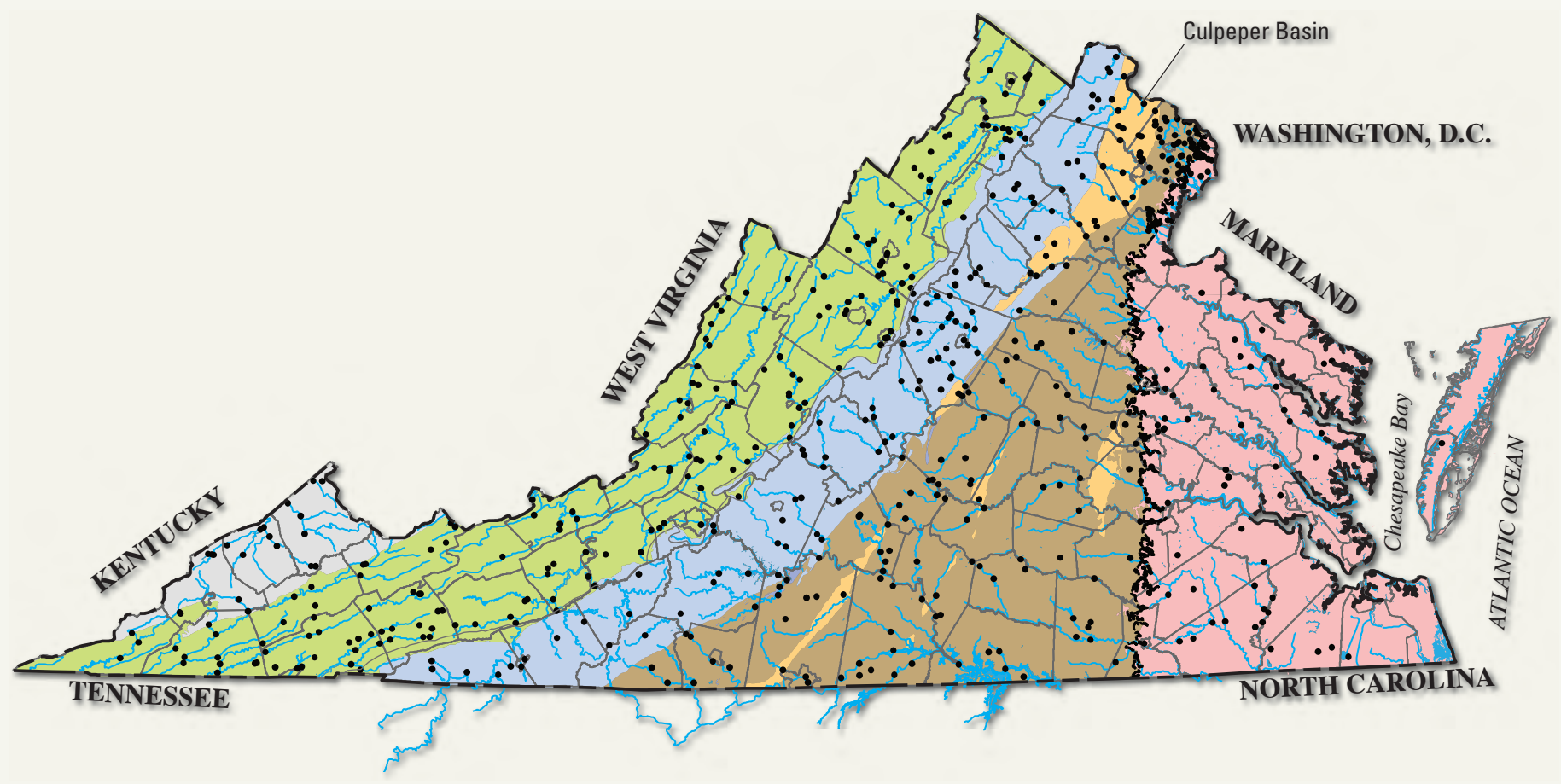

Scientific Investigations Report 2011-5144

U.S. Department of the Interior U.S. Geological Survey 
Cover art. See figure 1 (map showing peak-flow study sites in Virginia). 


\section{Peak-Flow Characteristics of Virginia Streams}

By Samuel H. Austin, Jennifer L. Krstolic, and Ute Wiegand

Prepared in cooperation with the Virginia Department of Transportation

Scientific Investigations Report 2011-5144 


\title{
U.S. Department of the Interior \\ KEN SALAZAR, Secretary \\ U.S. Geological Survey \\ Marcia K. McNutt, Director
}

\author{
U.S. Geological Survey, Reston, Virginia: 2011
}

For more information on the USGS - the Federal source for science about the Earth, its natural and living resources, natural hazards, and the environment, visit http://www.usgs.gov or call 1-888-ASK-USGS.

For an overview of USGS information products, including maps, imagery, and publications, visit http://www.usgs.gov/pubprod

To order this and other USGS information products, visit http://store.usgs.gov

Any use of trade, product, or firm names is for descriptive purposes only and does not imply endorsement by the U.S. Government.

Although this report is in the public domain, permission must be secured from the individual copyright owners to reproduce any copyrighted materials contained within this report.

Suggested citation:

Austin, S.H., Krstolic, J.L., and Wiegand, Ute, 2011, Peak-flow characteristics of Virginia streams: U.S. Geological Survey Scientific Investigations Report 2011-5144, 106 p. + 3 tables and 2 appendixes on CD.

(Also available online at http://pubs.usgs.gov/sir/2011/5144/.) 


\section{Contents}

Abstract

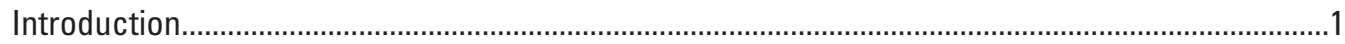

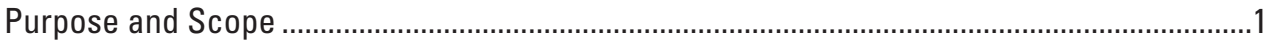

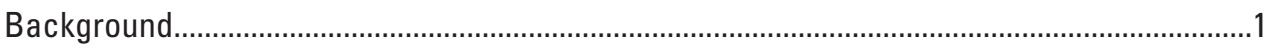

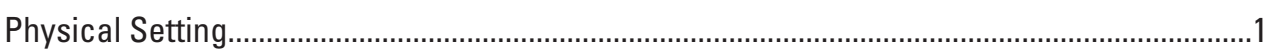

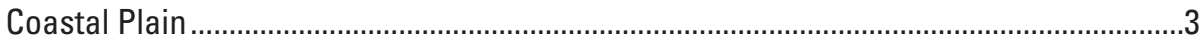

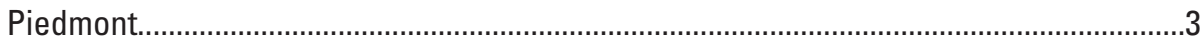

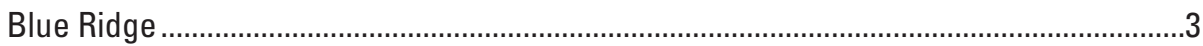

Valley and Ridge.......................................................................................................

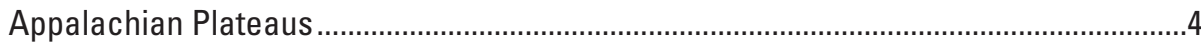

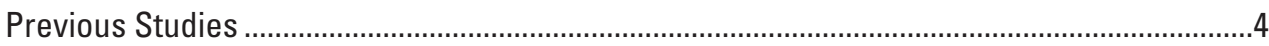

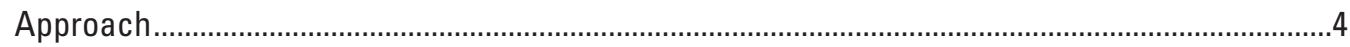

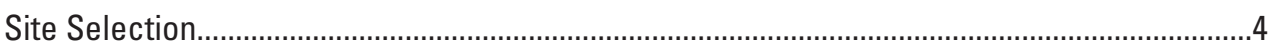

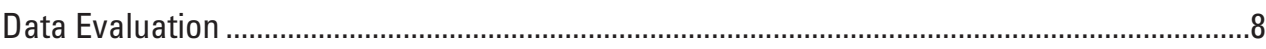

Flood-Frequency Analysis ...................................................................................................

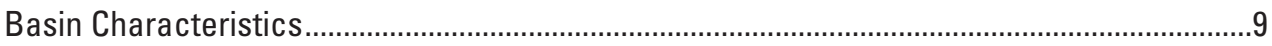

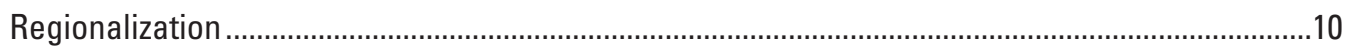

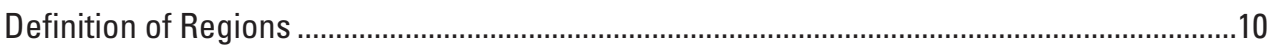

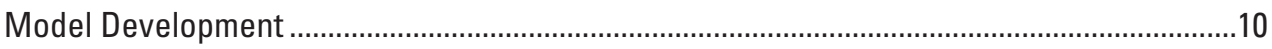

Model Verification and Diagnostics ..................................................................................

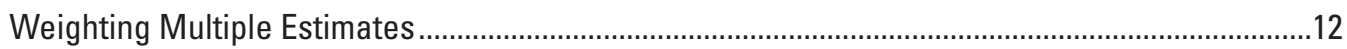

Weighting of Independent Estimates ............................................................................. 13

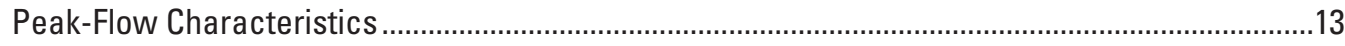

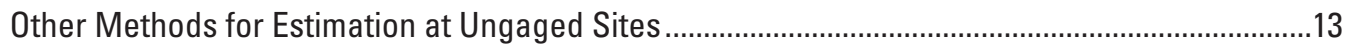

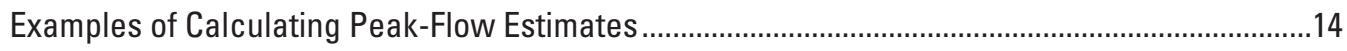

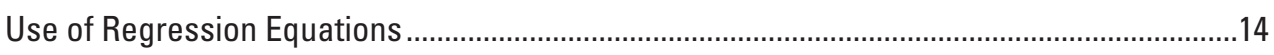

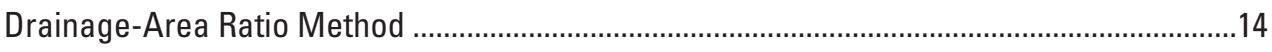

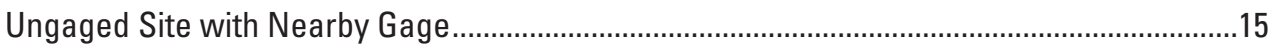

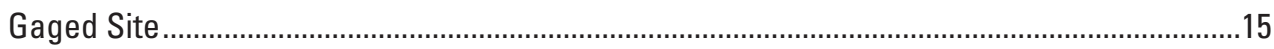

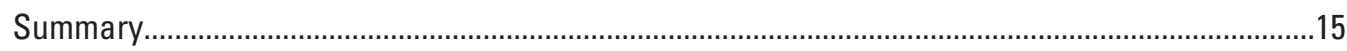

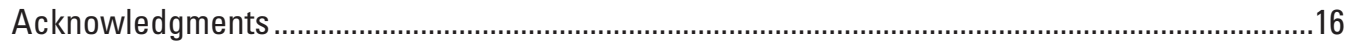

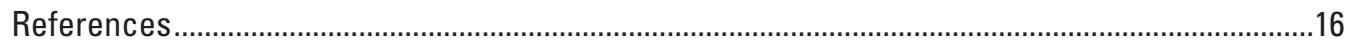

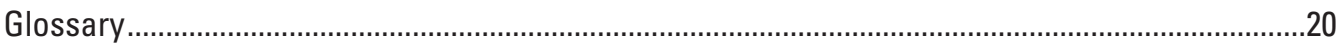

Appendix 1. Curves and residual plots for candidate single-parameter regional regression equations for estimating peak flows of streams in Virginia .............................................................................................. $\mathrm{CD}$ in pocket

Appendix 2. Curves and residual plots for candidate multi-parameter regional regression equations for estimating peak flows of streams in Virginia 


\section{Figures}

1. Map showing selected peak-flow study sites and physiographic provinces for application of peak-flow regional estimating equations...

2. Example leverage plots showing significant explanatory power, insignificant explanatory power, and evidence of collinearity.....

\section{Tables}

1. Sites used in the study and their identifying information CD in pocket

2. Peak-flow characteristics of streamgaging stations in Virginia ...21

3. Regional regression equations for estimating peak flows of streams in Virginia .5

4. Statistics summarizing basin characteristics selected for regional regression of peak flows in Virginia CD in pocket

5. Selected basin characteristics, their definitions, and datasources .6

6. Selected basin characteristics at peak-flow streamgaging stations in Virginia CD in pocket

\section{Conversion Factors}

Inch/Pound to SI

\begin{tabular}{|c|c|c|}
\hline Multiply & By & To obtain \\
\hline \multicolumn{3}{|c|}{ Length } \\
\hline inch (in.) & 2.54 & centimeter $(\mathrm{cm})$ \\
\hline inch (in.) & 25.4 & millimeter $(\mathrm{mm})$ \\
\hline foot $(\mathrm{ft})$ & 0.3048 & meter $(\mathrm{m})$ \\
\hline mile (mi) & 1.609 & kilometer (km) \\
\hline \multicolumn{3}{|c|}{ Area } \\
\hline acre & 0.4047 & hectare (ha) \\
\hline square mile $\left(\mathrm{mi}^{2}\right)$ & 259.0 & hectare (ha) \\
\hline \multicolumn{3}{|c|}{ Volume } \\
\hline gallon (gal) & 0.003785 & cubic meter $\left(\mathrm{m}^{3}\right)$ \\
\hline cubic foot $\left(\mathrm{ft}^{3}\right)$ & 0.02832 & cubic meter $\left(\mathrm{m}^{3}\right)$ \\
\hline acre-foot (acre-ft) & 1,233 & cubic meter $\left(\mathrm{m}^{3}\right)$ \\
\hline \multicolumn{3}{|c|}{ Flow rate } \\
\hline cubic foot per second $\left(\mathrm{ft}^{3} / \mathrm{s}\right)$ & 0.02832 & cubic meter per second $\left(\mathrm{m}^{3} / \mathrm{s}\right)$ \\
\hline \multicolumn{3}{|c|}{ Hydraulic gradient } \\
\hline foot per mile (ft/mi) & 0.1894 & meter per kilometer $(\mathrm{m} / \mathrm{km})$ \\
\hline
\end{tabular}

Vertical coordinate information is referenced to the North American Vertical Datum of 1929 (NAVD 29).

Horizontal coordinate information is referenced to the North American Datum of 1983 (NAD 83).

Elevation, as used in this report, refers to distance above the vertical datum. 


\title{
Peak-Flow Characteristics of Virginia Streams
}

\author{
By Samuel H. Austin, Jennifer L. Krstolic, and Ute Wiegand
}

\section{Abstract}

Peak-flow annual exceedance probabilities, also called probability-percent chance flow estimates, and regional regression equations are provided describing the peak-flow characteristics of Virginia streams. Statistical methods are used to evaluate peak-flow data. Analysis of Virginia peak-flow data collected from 1895 through 2007 is summarized. Methods are provided for estimating unregulated peak flow of gaged and ungaged streams. Station peak-flow characteristics identified by fitting the logarithms of annual peak flows to a LogPearson Type III frequency distribution yield annual exceedance probabilities of $0.5,0.4292,0.2,0.1,0.04,0.02,0.01$, 0.005 , and 0.002 for 476 streamgaging stations. Stream basin characteristics computed using spatial data and a geographic information system are used as explanatory variables in regional regression model equations for six physiographic regions to estimate regional annual exceedance probabilities at gaged and ungaged sites. Weighted peak-flow values that combine annual exceedance probabilities computed from gaging station data and from regional regression equations provide improved peak-flow estimates. Text, figures, and lists are provided summarizing selected peak-flow sites, delineated physiographic regions, peak-flow estimates, basin characteristics, regional regression model equations, error estimates, definitions, datasources, and candidate regression model equations. This study supersedes previous studies of peak flows in Virginia.

\section{Introduction}

Understanding peak water flows in Virginia streams is essential to human safety and sound management of our water resources and associated riparian and watershed ecosystems. Meaningful characterizations of the magnitude and frequency of peak flows provide valuable insights into the dynamics and variability of water movement through these unique stream systems. Improved estimates of peak flows are helpful for management decisions including (1) locating highways, industries, railroads, farms, and residences, (2) designing and building bridges, dams, reservoirs, levees, floodwalls, and culverts, and (3) effectively managing the riparian systems and ecology associated with forested, agricultural, and urban landscapes. Peak-flow estimates provide a basis for analysis of future streamflow response to changes in ecosystem and climate.

\section{Purpose and Scope}

This report summarizes a statistical analysis of peak-flow data collected in Virginia from 1895 through 2007. Methods are provided for estimating the peak flow of gaged and ungaged streams in Virginia. Basin characteristics and station peak-flow characteristics are presented for 476 streamgaging stations located throughout the State. Regression methods are used with gaging-station records to develop regional equations to estimate peak flows at ungaged sites. Regional regression equations are presented for six peak-flow regions based on physiography to estimate peak flows at ungaged sites in each region. Methods are provided to incorporate peak-flow data at gaging stations with regional estimates and to improve peak-flow estimates at sites where nearby gaging-station records are available. This study supersedes previous studies of peak flows in Virginia.

\section{Background}

Since 1949, the U.S. Geological Survey (USGS), in cooperation with the Virginia Department of Transportation (VDOT), has maintained a network of partial-record peakflow gaging stations. Records from continuous-record and partial-record gaging stations provide annual peak-flow data throughout Virginia (Prugh and others, 1991; Bisese, 1995). In this cooperative study with VDOT, peak-flow data from 476 streamgaging stations were used to provide detailed analysis of the magnitude and frequency of peak flows at gaged sites. Equations were developed for estimating peak flows at ungaged locations. These data and methods support evaluation by VDOT of peak flows throughout Virginia.

\section{Physical Setting}

Virginia is located on the Atlantic Coast, bordered to the north by Maryland and West Virginia, to the south by North Carolina and Tennessee, and to the west by Kentucky and West Virginia, (fig. 1). The total area of Virginia is 


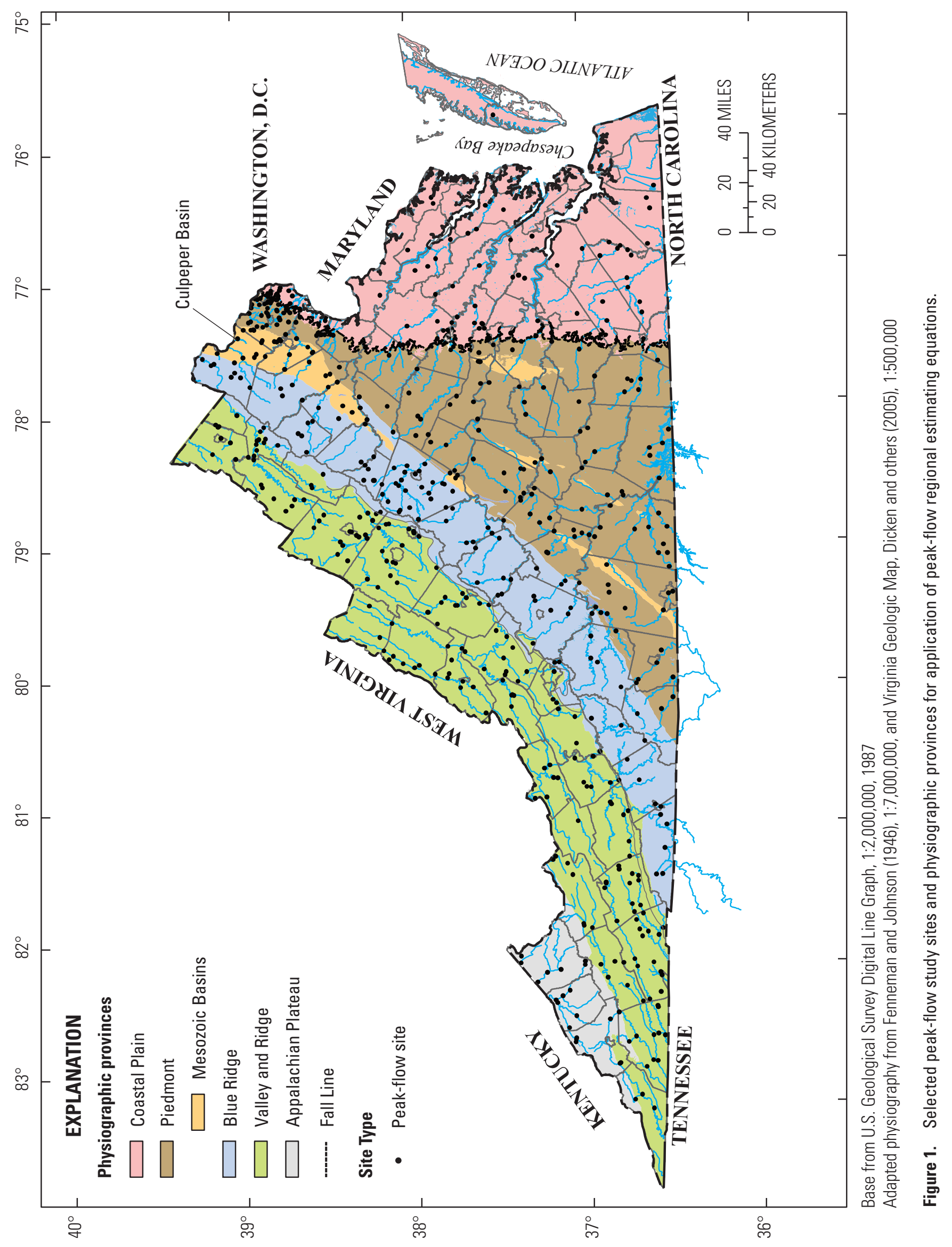


approximately 41,000 square miles $\left(\mathrm{mi}^{2}\right)$. This includes almost $1,000 \mathrm{mi}^{2}$ of lakes, tidal rivers, and bays. There are more than 3,000 miles (mi) of nontidal rivers and more than 5,000 mi of shoreline along the Atlantic Coast and Chesapeake Bay (Fenneman, 1938; Fenneman and Johnson, 1946).

Virginia lies within five physiographic provinces - the Coastal Plain, Piedmont, Blue Ridge, Valley and Ridge, and Appalachian Plateaus Physiographic Provinces. Each province, hereafter termed physiographic region or peak-flow region, has distinctive geologic features and landforms. Geology ranges from unconsolidated sands and clays in the Coastal Plain physiographic region, to igneous and metamorphic rocks in the Piedmont and Blue Ridge physiographic regions, to sedimentary rocks, carbonate rocks, sandstone, and shale in the Valley and Ridge and Appalachian Plateaus physiographic regions (Hayes, 1991). Topography ranges from virtually flat in the Coastal Plain to highly dissected rugged terrain along the Blue Ridge and Appalachian crests. The central Piedmont is characterized by rolling hills and valleys, and is separated from the Valley and Ridge physiographic region by the Blue Ridge Mountains. Land-surface elevations range from 0 feet (ft) to over 5,000 ft above sea level (Fenneman, 1938).

\section{Coastal Plain}

The Coastal Plain physiographic region (Coastal Plain) generally consists of unconsolidated, gently sloping layers of sand and gravel separated by layers of clay and marl. The eastern boundary of the Coastal Plain is the Atlantic Ocean. The western boundary is the Fall Line, where the resistant rock of the Piedmont forms a contact with the unconsolidated sediments of the Coastal Plain (Fenneman, 1938). Sediments are thin at the Fall Line and thicken to as much as $6,000 \mathrm{ft}$ at the eastern edge of the Coastal Plain and are more than 13,000 ft thick under the Continental Shelf. These sediments rest on an eroded surface of Precambrian to early Mesozoic rock. Two-thirds of this material is composed of late Jurassic and Cretaceous clay, sand, and gravel, which was stripped from the Appalachian mountains, carried eastward by rivers, and deposited in deltas in the newly formed Atlantic Ocean basin. A sequence of thin, fossiliferous marine sands of Tertiary age overlies the older strata. These sands were deposited in warm, shallow seas during repeated marine transgressions across the Coastal Plain (Hayes, 1991). This pattern of deposition was interrupted about 35 million years ago by a large meteorite that plummeted into a shallow sea and created a crater more than $55 \mathrm{mi}$ in diameter, termed the Chesapeake Bay impact structure, which was subsequently buried under about 4,000 ft of younger sediment (Edwards and others, 2005). Rivers and streams are affected by tides over a substantial area (Fenneman, 1938; Fenneman and Johnson, 1946).

\section{Piedmont}

The Piedmont physiographic region (Piedmont) in Virginia consists of gently rolling terrain, which extends from the base of the Blue Ridge Mountains east to the Fall Line. It is the largest physiographic region in Virginia, is widest along the Virginia-North Carolina border (approximately $125 \mathrm{mi}$ wide), then narrows to about 25 mi wide in northern Virginia. The Piedmont is formed mainly of metamorphic and igneous rocks that consist of granite, gneiss, schist, slate, phyllite, and quartzite. Triassic and Jurassic sedimentary rocks form several early Mesozoic Basins in the Piedmont that consist mainly of shales and sandstones intruded by diabase. Geologic formations of the Piedmont trend northeast-southwest and generally are covered by a deep ( 6 to $65 \mathrm{ft}$ ) layer of saprolite. Outcrops commonly are restricted to stream valleys where saprolite has been removed by erosion. The topography becomes somewhat more rugged with proximity to the Blue Ridge physiographic region, where local hills, knobs, or ridges of more resistant rock are present (Fenneman, 1938).

The Mesozoic Basins are located within the Piedmont, but they are evaluated as a separate physiographic region in this study because of their unique geomorphology and the associated improvements in explanatory power of basin characteristics in regional regression equations developed specifically for Mesozoic Basins. The Mesozoic Basins consist of sediments deposited in fault basins and are usually referred to as Triassic Basin deposits, though they are known to also contain lower Jurassic rocks. These basins formed when Africa separated from North America to create the Atlantic Ocean. The Culpeper basin in the western Piedmont near the Blue Ridge physiographic region is the largest Mesozoic Basin in Virginia, but smaller basins, including the Richmond, Farmville, and Danville, are scattered throughout the Piedmont. Structurally, these are partially depressed blocks of land with a main fault on the western side. Ancient alluvial fan conglomerates fill these basins along the western borders, and deep red sediments often containing fish fossils or dinosaur tracks fill the eastern portions of these basins, indicating that tropical lakes and mudflats were present. Numerous igneous rocks and lava flows are cut into these Triassic sediments and are remnants of the volcanic activity that accompanied the opening of the Atlantic Ocean (Hayes, 1991).

\section{Blue Ridge}

The Blue Ridge physiographic region (Blue Ridge) lies between the Valley and Ridge physiographic region and the Piedmont physiographic region. It is a fairly thin ridge of northeast-southwest-trending mountains consisting mainly of metamorphic and igneous rocks, with some sedimentary rock on the western slope. By the early Cambrian, the Iapetus Ocean had opened to the east of the Blue Ridge, and a westward transgression occurred along the ancient North American margin. In the western Blue Ridge, shallow marine siliclastics of the Chilhowee Group were deposited in the early Cambrian and eventually gave way to carbonates of CambroOrdovician age. In central and northern Virginia, the Blue Ridge Mountains rise to elevations exceeding 4,000 ft. Local relief on the east side of the Blue Ridge is up to 3,000 ft. In 
southern Virginia, the Blue Ridge forms a broad plateau-like upland that rises over 1,500 $\mathrm{ft}$ from the Piedmont along a prominent escarpment. Mt. Rogers $(5,728 \mathrm{ft})$, in the southwestern Virginia Blue Ridge, is the highest peak in Virginia. Steep slopes allow only thin soils in some areas, thus reducing the amount of groundwater storage (Hayes, 1991).

\section{Valley and Ridge}

The Valley and Ridge physiographic region (Valley and Ridge) was formed by the folding and faulting of sedimentary rocks. Northeast-southwest-trending ridges are formed by resistant quartzite, sandstone, and conglomerates, while narrow valleys are underlain by limestone, shale, and dolostone. The characteristic topography of this region is the result of differential weathering of linear belts of rocks that has been repeated by folding and faulting. Cambrian clastic sediments of the western Blue Ridge are overlain by carbonate rocks. For at least 70 million years, carbonates were deposited in a shallow, tropical ocean along the southeastern edge of North America. Today these carbonates, up to 2 mi thick, are exposed in the Great Valley, known as the Shenandoah Valley in central and northern Virginia, and in the easternmost part of the Valley and Ridge. Well-developed karst topography is characteristic of the Great Valley, and many caverns are located in the subsurface (Hayes, 1991).

\section{Appalachian Plateaus}

The Appalachian Plateaus physiographic region (Appalachian Plateaus), locally known as the Cumberland Plateau, consists of westward-dipping, consolidated, sedimentary rocks composed mainly of sandstone, shale, and coal. It is located at the western end of Virginia. Extensive erosion has formed steep slopes and narrow valleys throughout this province. Although some parts of the Appalachian Plateaus exhibit a low relief plateau-like morphology, much of the Appalachian Plateaus is strongly dissected by stream erosion, and the topography is rugged. Regional-scale folds in the Appalachian Plateaus were formed in response to shortening on thrust faults that do not reach the present surface and are rooted to the east in the Valley and Ridge. The upper Paleozoic strata of the Appalachian Plateaus are rich in mineral resources, such as coal, natural gas, and petroleum (Fenneman, 1938; Fenneman and Johnson, 1946).

\section{Previous Studies}

Previous statistical analyses of peak-flow data in Virginia have been reported by Tice (1950), Speer and Gamble (1964a, 1964b, 1965), Miller (1969, 1978), and Bisese (1995). This study builds on these earlier analyses, incorporating 12 years of data collected since Bisese's (1995) report. Population has increased, urban areas have expanded, and land use has changed at an accelerating pace since Bisese's study was published.

\section{Approach}

Peak-flow characteristics were determined by flood-frequency analysis and regional regression of basin characteristics. Study sites were selected, data were evaluated, basin characteristics were compiled, and flood-frequency and regional analyses were performed.

Flood-frequency analysis consisted of fitting the logarithms of annual peak flows for 476 streamgaging stations to a Log-Pearson Type III frequency distribution yielding annual exceedance probabilities of $0.5,0.4292,0.2,0.1,0.04$, $0.02,0.01,0.005$, and 0.002 . Regional regression of basin characteristics consisted of using spatial data and a geographic information system to compute basin characteristics, and using basin characteristics as explanatory variables in regional regression equations specific to six physiographic regions to estimate regional annual exceedance probabilities. Past USGS publications that describe peak-flow characteristics have often reported these values using a recurrence interval format. Annual exceedance probability (AEP), now recognized as a preferred reporting format, is used in this report.

Study results are presented in six tables and two appendixes. Sites selected for study are identified in table 1 (compact disc (CD) in pocket). Peak-flow characteristics from Log-Pearson Type III analyses, weighted peak-flow estimates, and estimates based on regional regression equations are summarized in table 2 (p. 21). Peak-flow regional regression equations are listed in table 3 . Statistics summarizing selected basin characteristics are presented in table 4 (CD in pocket). Table 5 lists selected basin characteristic definitions and datasources. Table 6 (CD in pocket) lists values of selected basin characteristics for each study site. Appendix 1 shows curves and residual plots describing the candidate single-parameter regional regression equations for estimating peak flows of streams in Virginia. Appendix 2 shows curves and residual plots describing the candidate multi-parameter regional regression equations for estimating peak flows of streams in Virginia. (Appendixes are on CD in pocket.)

\section{Site Selection}

Streamgaging stations with at least 10 years of continuous record were identified as candidates for study. All of these streamgaging stations were considered, including those in predominately urban and predominately rural basins. Peak-flow data from each candidate streamgaging station were quality checked to identify any numerical errors. Then, a data table was created for each candidate streamgaging station listing all datapoints collected during the period of record. Each list of datapoints was individually evaluated using written accounts of past data-collection procedures and anecdotal information specific to each gaging site, to discover and segregate any intervals in the record in which concomitant effects such as data of poor quality or severely altered or regulated flows negatively affected the candidate data. Data 
Table 3. Regional regression equations for estimating peak flows of streams in Virginia.

[DA, basin drainage area in square miles]

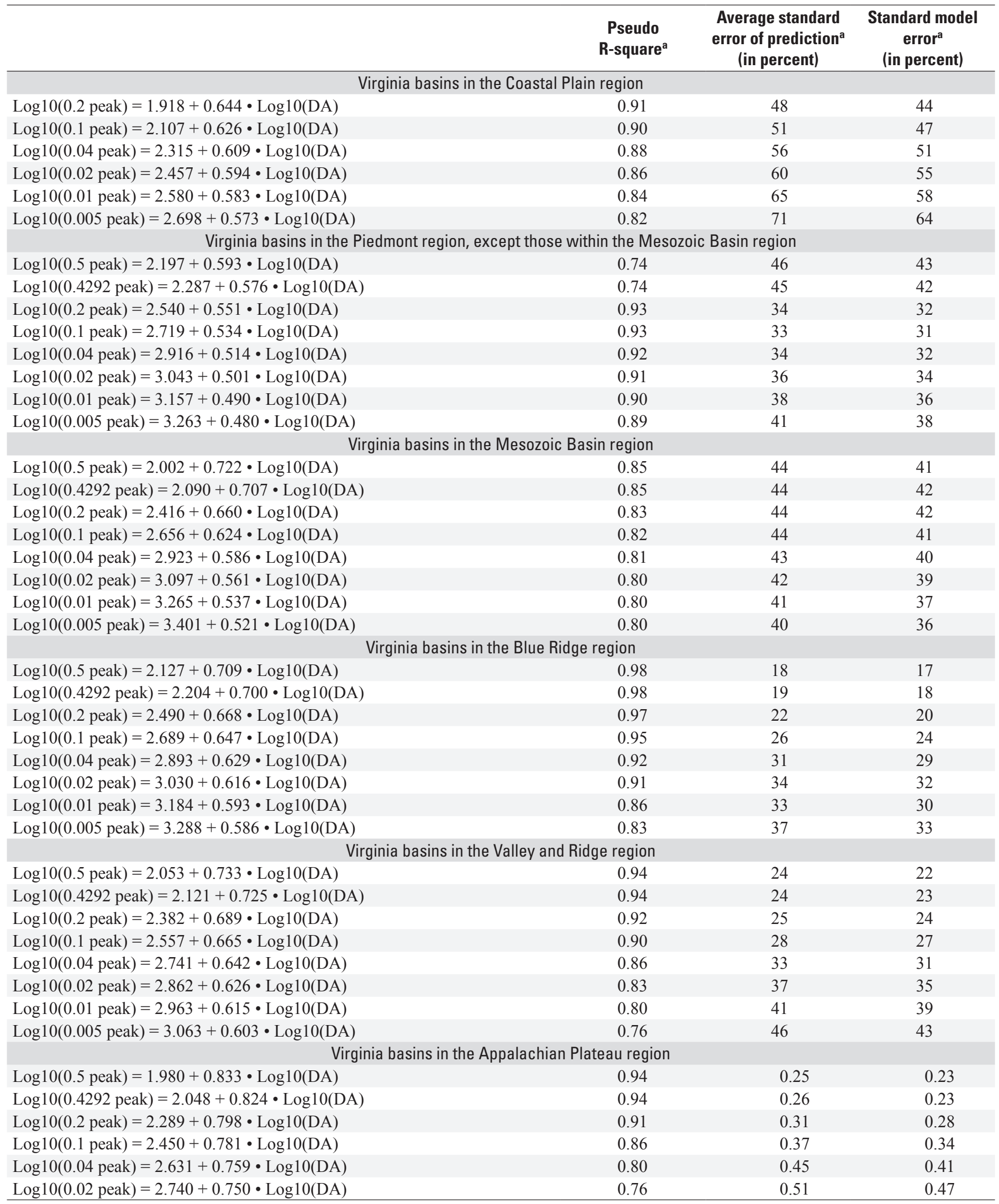

${ }^{\mathrm{a}}$ Generalized least squares regression. 
Table 5. Selected basin characteristics, their definitions, and datasources.

[ft, foot; $\mathrm{mi}^{2}$, square mile; ft/mi, foot per mile; DD, decimal degrees; in., inch]

\begin{tabular}{|c|c|c|c|}
\hline Basin characteristic & Units & Definition & Datasource \\
\hline Mean elevation & $\mathrm{ft}$ & The average elevation in the basin. & U.S. Geological Survey, 2007, National Elevation Data Set (NED) \\
\hline Drainage area & $\mathrm{mi}^{2}$ & $\begin{array}{l}\text { Published values of surface drainage area for each } \\
\text { basin in the study. }\end{array}$ & Hayes and Wiegand, 2006 \\
\hline Basin slope & $\mathrm{ft} / \mathrm{mi}$ & The average slope of the basin from upland to outlet. & U.S. Geological Survey, 2007, National Elevation Data Set (NED) \\
\hline Perimeter & $\mathrm{mi}$ & The length of the basin boundary. & U.S. Geological Survey, 2007, National Elevation Data Set (NED) \\
\hline Latitude & DD & $\begin{array}{l}\text { The east-west coordinate at the } \\
\text { centroid of the basin boundary. }\end{array}$ & U.S. Geological Survey, 2007, National Elevation Data Set (NED) \\
\hline Longitude & DD & $\begin{array}{l}\text { The north-south coordinate at the centroid of the basin } \\
\text { boundary. }\end{array}$ & U.S. Geological Survey, 2007, National Elevation Data Set (NED) \\
\hline Elevation & $\mathrm{ft}$ & $\begin{array}{l}\text { The distance above sea level associated with the center } \\
\text { point of the watershed polygon. }\end{array}$ & U.S. Geological Survey, 2007, National Elevation Data Set (NED) \\
\hline Basin relief & $\mathrm{ft}$ & $\begin{array}{l}\text { The difference between maximum and minimum eleva- } \\
\text { tion within the basin. }\end{array}$ & U.S. Geological Survey, 2007, National Elevation Data Set (NED) \\
\hline Valley length & $\mathrm{mi}$ & The length of the main valley within the basin. & U.S. Geological Survey, 2007, National Elevation Data Set (NED) \\
\hline Channel slope & $\mathrm{ft} / \mathrm{mi}$ & The slope of the main chanel within the basin. & U.S. Geological Survey, 2007, National Elevation Data Set (NED) \\
\hline Elevation at 10 percent & $\mathrm{ft}$ & $\begin{array}{l}\text { The distance above sea level associated with the main } \\
\text { channel at } 10 \text { percent of the basin drainage area from } \\
\text { the outlet. }\end{array}$ & U.S. Geological Survey, 2007, National Elevation Data Set (NED) \\
\hline Elevation at 85 percent & $\mathrm{ft}$ & $\begin{array}{l}\text { The distance above sea level associated with the main } \\
\text { channel at } 85 \text { percent of the basin drainage area from } \\
\text { the outlet. }\end{array}$ & U.S. Geological Survey, 2007, National Elevation Data Set (NED) \\
\hline
\end{tabular}

$\begin{array}{lll}\begin{array}{l}\text { Stream length } \\ \text { Forest }\end{array} & \begin{array}{c}\text { Length along the main channel from the outlet to the } \\ \text { basin divide. }\end{array} \\ \begin{array}{l}\text { Urban } \\ \text { Agriculture }\end{array} & \begin{array}{c}\text { percent } \\ \text { percent } \\ \text { percent }\end{array} & \begin{array}{c}\text { Fraction of basin land area classified as forest. } \\ \text { Fraction of basin land area classified as urban area. } \\ \text { Fraction of basin land area classified as agricultural } \\ \text { land. }\end{array} \\ \text { Wetland } & \text { percent } & \text { Fraction of basin land area classified as wetland. } \\ \text { Water } & \text { percent } & \text { Fraction of basin land area classified as surface water. } \\ \text { Grass } & \text { percent } & \text { Fraction of basin land area classified as grassland. } \\ \text { Bare } & \text { percent } & \text { Fraction of basin land area classified as exposed soil. } \\ \text { Basin area in Coastal } & \text { mi }{ }^{2} & \text { Area within the Coastal Plain } \\ \text { Plain physiographic } & & \text { physiographic region. }\end{array}$

Basin area in Piedmont $\mathrm{mi}^{2} \quad$ Area within the Piedmont physiographic region. physiographic region

Basin area in Blue $\quad \mathrm{mi}^{2}$ Ridge physiographic region

Basin area in Valley and $\mathrm{mi}^{2}$ Ridge physiographic region

Basin area in Ap- $\quad \mathrm{mi}^{2}$ palachian Plateaus physiographic region

Basin area in Mesozoic $\mathrm{mi}^{2}$ Basins physiographic region

Basin area in water $\mathrm{mi}^{2}$

Basin area in Coastal Plain physiographic region

Basin area in Piedmont physiographic region

Basin area in Blue Ridge physiographic region region.

Area within the Mesozoic Basin physiographic region.
U.S. Geological Survey, 2006, National Hydrography Dataset

Homer and others, 2004, http://www.mrlc.gov/nlcd.php

Homer and others, 2004, http://www.mrlc.gov/nlcd.php

Homer and others, 2004, http://www.mrlc.gov/nlcd.php

Homer and others, 2004, http://www.mrlc.gov/nlcd.php

Homer and others, 2004, http://www.mrlc.gov/nlcd.php

Homer and others, 2004, http://www.mrlc.gov/nlcd.php

Homer and others, 2004, http://www.mrlc.gov/nlcd.php

Fenneman and Johnson, 1946; Mixon and others, 1989; Dicken and others, 2005

Fenneman and Johnson, 1946; Mixon and others, 1989; Dicken and others, 2005

Fenneman and Johnson, 1946; Mixon and others, 1989; Dicken and others, 2005

Area within the Valley and Ridge physiographic region. Fenneman and Johnson, 1946; Mixon and others, 1989; Dicken and others, 2005

Fenneman and Johnson, 1946; Mixon and others, 1989; Dicken and others, 2005

Fenneman and Johnson, 1946; Mixon and others, 1989; Dicken and others, 2005

Fenneman and Johnson, 1946; Mixon and others, 1989; Dicken and others, 2005

Fenneman and Johnson, 1946; Mixon and others, 1989; Dicken and others, 2005

Fenneman and Johnson, 1946; Mixon and others, 1989; Dicken and others, 2005

Fenneman and Johnson, 1946; Mixon and others, 1989; Dicken and others, 2005 
Table 5. Selected basin characteristics, their definitions, and datasources.-Continued

[ft, foot; $\mathrm{mi}^{2}$, square mile; ft/mi, foot per mile; DD, decimal degrees; in., inch]

\begin{tabular}{|c|c|c|c|}
\hline Basin characteristic & Units & Definition & Datasource \\
\hline $\begin{array}{l}\text { Basin area in Valley and } \\
\text { Ridge physiographic } \\
\text { region }\end{array}$ & percent & $\begin{array}{l}\text { Percent of the basin within the Valley and Ridge phys- } \\
\text { iographic region. }\end{array}$ & $\begin{array}{l}\text { Fenneman and Johnson, 1946; Mixon and others, 1989; Dicken and } \\
\text { others, } 2005\end{array}$ \\
\hline $\begin{array}{l}\text { Basin area in Ap- } \\
\text { palachian Plateau } \\
\text { physiographic region }\end{array}$ & percent & $\begin{array}{l}\text { Percent of the basin within the Appalachian Plateau } \\
\text { physiographic region. }\end{array}$ & $\begin{array}{l}\text { Fenneman and Johnson, 1946; Mixon and others, 1989; Dicken and } \\
\text { others, } 2005\end{array}$ \\
\hline $\begin{array}{l}\text { Basin area in Mesozoic } \\
\text { Basin physiographic } \\
\text { region }\end{array}$ & percent & $\begin{array}{l}\text { Percent of the basin within the Mesozoic Basin physio- } \\
\text { graphic region. }\end{array}$ & $\begin{array}{l}\text { Fenneman and Johnson, 1946; Mixon and others, 1989; Dicken and } \\
\text { others, } 2005\end{array}$ \\
\hline Basin area in water & percent & Percent of basin area covered in surface water. & $\begin{array}{l}\text { Fenneman and Johnson, 1946; Mixon and others, 1989; Dicken and } \\
\text { others, } 2005\end{array}$ \\
\hline $\begin{array}{l}\text { Mean annual precipita- } \\
\text { tion }\end{array}$ & in. & $\begin{array}{l}\text { Mean annual precipitation falling on the basin, aver- } \\
\text { aged over the whole basin. }\end{array}$ & PRISM Climate Group, 2007; Paybins, 2008 \\
\hline $\begin{array}{l}\text { Mean January-Febru- } \\
\text { ary-March precipita- } \\
\text { tion }\end{array}$ & in. & $\begin{array}{l}\text { Mean January-February-March precipitation falling on } \\
\text { the basin, averaged over the whole basin. }\end{array}$ & PRISM Climate Group, 2007 \\
\hline $\begin{array}{l}\text { 2-year 24-hour precipi- } \\
\text { tation intensity }\end{array}$ & in. & $\begin{array}{l}\text { Basin average rainfall at the 24-hour 2-year recurrence } \\
\text { interval. }\end{array}$ & $\begin{array}{l}\text { National Oceanic and Atmospheric Administration, 2007; Paybins, } \\
2008\end{array}$ \\
\hline $\begin{array}{l}\text { Basin area with } \\
0 \text { percent impervious } \\
\text { surface }\end{array}$ & percent & Percent of the basin coded as 0 percent impervious. & Yang and others, 2002; Homer and others, 2004 \\
\hline $\begin{array}{l}\text { Basin area with } \\
1-5 \text { percent impervi- } \\
\text { ous surface }\end{array}$ & percent & Percent of the basin coded as 1 to 5 percent impervious. & Yang and others, 2002; Homer and others, 2004 \\
\hline $\begin{array}{l}\text { Basin area with } \\
6-10 \text { percent imper- } \\
\text { vious surface }\end{array}$ & percent & $\begin{array}{l}\text { Percent of the basin coded as } 6 \text { to } 10 \text { percent impervi- } \\
\text { ous. }\end{array}$ & Yang and others, 2002; Homer and others, 2004 \\
\hline $\begin{array}{l}\text { Basin area with } \\
11-25 \text { percent imper- } \\
\text { vious surface }\end{array}$ & percent & $\begin{array}{l}\text { Percent of the basin coded as } 11 \text { to } 25 \text { percent impervi- } \\
\text { ous. }\end{array}$ & Yang and others, 2002; Homer and others, 2004 \\
\hline $\begin{array}{l}\text { Basin area with } \\
26-50 \text { percent im- } \\
\text { pervious surface }\end{array}$ & percent & $\begin{array}{l}\text { Percent of the basin coded as } 26 \text { to } 50 \text { percent impervi- } \\
\text { ous. }\end{array}$ & Yang and others, 2002; Homer and others, 2004 \\
\hline $\begin{array}{l}\text { Basin area with } \\
51-75 \text { percent im- } \\
\text { pervious surface }\end{array}$ & percent & $\begin{array}{l}\text { Percent of the basin coded as } 51 \text { to } 75 \text { percent impervi- } \\
\text { ous. }\end{array}$ & Yang and others, 2002; Homer and others, 2004 \\
\hline $\begin{array}{l}\text { Basin area with } \\
\quad 76-100 \text { percent } \\
\text { impervious surface }\end{array}$ & percent & $\begin{array}{l}\text { Percent of the basin coded as } 76 \text { to } 100 \text { percent imper- } \\
\text { vious. }\end{array}$ & Yang and others, 2002; Homer and others, 2004 \\
\hline $\begin{array}{l}\text { Basin area with } \\
0 \text { percent impervious } \\
\text { surface }\end{array}$ & $\mathrm{mi}^{2}$ & Area within the basin coded as 0 percent impervious. & Yang and others, 2002; Homer and others, 2004 \\
\hline $\begin{array}{l}\text { Basin area with } \\
1-5 \text { percent impervi- } \\
\text { ous surface }\end{array}$ & $\mathrm{mi}^{2}$ & $\begin{array}{l}\text { Area within the basin coded as } 1 \text { to } 5 \text { percent impervi- } \\
\text { ous. }\end{array}$ & Yang and others, 2002; Homer and others, 2004 \\
\hline $\begin{array}{l}\text { Basin area with } \\
6-10 \text { percent imper- } \\
\text { vious surface }\end{array}$ & $\mathrm{mi}^{2}$ & $\begin{array}{l}\text { Area within the basin coded as } 6 \text { to } 10 \text { percent impervi- } \\
\text { ous. }\end{array}$ & Yang and others, 2002; Homer and others, 2004 \\
\hline $\begin{array}{l}\text { Basin area with } \\
11-25 \text { percent imper- } \\
\text { vious surface }\end{array}$ & $\mathrm{mi}^{2}$ & $\begin{array}{l}\text { Area within the basin coded as } 11 \text { to } 25 \text { percent imper- } \\
\text { vious. }\end{array}$ & Yang and others, 2002; Homer and others, 2004 \\
\hline $\begin{array}{l}\text { Basin area with } \\
26-50 \text { percent im- } \\
\text { pervious surface }\end{array}$ & $\mathrm{mi}^{2}$ & $\begin{array}{l}\text { Area within the basin coded as } 26 \text { to } 50 \text { percent imper- } \\
\text { vious. }\end{array}$ & Yang and others, 2002; Homer and others, 2004 \\
\hline $\begin{array}{l}\text { Basin area with } \\
51-75 \text { percent im- } \\
\text { pervious surface }\end{array}$ & $\mathrm{mi}^{2}$ & $\begin{array}{l}\text { Area within the basin coded as } 51 \text { to } 75 \text { percent imper- } \\
\text { vious. }\end{array}$ & Yang and others, 2002; Homer and others, 2004 \\
\hline $\begin{array}{l}\text { Basin area with } \\
76-100 \text { percent } \\
\text { impervious surface }\end{array}$ & $\mathrm{mi}^{2}$ & $\begin{array}{l}\text { Area within the basin coded as } 76 \text { to } 100 \text { percent } \\
\text { impervious. }\end{array}$ & Yang and others, 2002; Homer and others, 2004 \\
\hline
\end{tabular}


within these affected intervals were segregated from the larger dataset and not used in further analysis.

Similarly, using professional judgment, basin drainage area and usable watershed storage volume upstream from the gaging location were calculated for each candidate dataset in which regulation was suspected. If the calculated volume of usable water storage upstream from the gaging site met or exceeded 100 acre-feet per square mile, an amount considered to significantly regulate streamflow, then the gaging station was eliminated as a candidate site (Benson, 1962, 1964). Streamgaging stations used in this study are listed in table 1 (CD in pocket).

\section{Data Evaluation}

Datapoints from each remaining dataset were plotted in station-specific scatter plots, and each scatter plot was visually checked for evidence of trends. Summary statistics were generated for each dataset along with additional statistics useful for identifying trends in data and monotonic, non-monotonic, linear, and non-linear correlation, including (1) calculating Kendall's Tau, (2) creating an index of Kendall's trend probability, and (3) calculating Spearman's rho to help determine the strength of any linear or non-linear monotonic trend (Helsel and Hirsch, 2002). Other statistical analyses include (4) calculating and plotting a linear regression of each dataset with time, (5) plotting residuals to help identify any significant correlation with time and, if evident, any negative or positive autocorrelation, and (6) performing a runs test of each dataset to help determine any significantly non-linear change over time using GraphPad Prism. ${ }^{1}$

The results of these statistical tests were summarized for each candidate dataset and used to help determine the degree of significant auto-correlation within the data of each candidate site. If no significant trend was evident at the 0.05 confidence level, the candidate site became part of the study pool. If a significant trend was evident in the dataset of a candidate site, the trend in the data was further evaluated to determine if (1) the trend could be directly attributed to a causal factor or (2) the trend produced values that exceed those normally expected from a random sample. If the trend could not be directly attributed to a causal factor or trend values ranged within the bounds of expected statistical variation, then the trend was considered non-problematic and no efforts were made to compensate for it by adjusting the station dataset. If the trend could be attributed to a causal factor or trend values were determined to range outside the bounds of expected statistical variation, then several methods to evaluate the dataset and remove the trend were considered. These methods included (1) testing the dataset against an annual precipitation time series to identify any correlation with annual precipitation, (2) sampling from the dataset, then re-evaluating the auto-correlation of the sample, (3) grouping the data into

\footnotetext{
${ }^{1}$ GraphPad Prism version 5.0b, 2009, GraphPad Software, San Diego, California.
}

alternate time periods and computing a summary statistic for the period, such as a time-weighted mean or median, and (4) removing the dataset from the pool of sites to be analyzed. If trends persisted in the revised dataset, then the candidate dataset was removed from consideration as a possible study site.

Of the 589 candidate datasets considered for study, 113 were removed from consideration because they either had too few datapoints available for analysis, or they characterized streams with excessively regulated flow. Of the remaining 476 sites, statistical trends were identified in 68 datasets. None of these trends were determined to be problematic, and none were detrended by sampling from the dataset and re-evaluating the auto-correlation of the sample. Thirty of these datasets were partially censored due to indications of excessively regulated flow, and 5 datasets were partially censored because too many peak flows were measured below the gage base. These partially censored datasets were then used in the analysis.

\section{Flood-Frequency Analysis}

Log-Pearson Type III adjusted flood-frequency analyses of data from each of the 476 selected gaging stations were used to determine peak flows at each site. The Log-Pearson Type III analyses were performed using program PeakFQ (Flynn and others, 2006) following methods outlined in the revised Bulletin 17B of the Hydrology Subcommittee of the Interagency Advisory Committee on Water Data (Interagency Advisory Committee on Water Data, 1982). These analyses involve fitting a Pearson Type III frequency distribution to the logarithms of annual peak flows and are used by all Federal agencies for determining flood frequency. Major steps performed as part of this process are summarized below.

1. Systematic-Record Analysis. An analysis of the systematic record of data collected at each selected gage was performed to compute the mean, standard deviation, and coefficient of skewness (mean X, S, and G, respectively) of the common logarithms of the annual peak flows.

2. Outlier Tests. Peaks that departed substantially from the trend of the remaining peaks were classified as outliers. Adjustments of the initial frequency curve involved detecting and accounting for high and low outliers. An iterative sequence of tests and adjustments was made to each initial frequency curve to compensate for outlier values. The order of this sequence of adjustments was dependent on the station skew coefficient, G, as computed in the systematic-record analysis.

3. Historical-Record Adjustment. Recalculation of the statistics of the above-base peaks was performed after detection of outliers or historical information such as historical peaks, as specified in Appendix 6 of Bulletin 17B (Interagency Advisory Committee on Water Data, 1982). This historical adjustment filled in the ungaged portion of the historic period in each record with an appropriate 
number of replications of the below-historical threshold streamflow portion of the systematic record.

4. Conditional-Probability Adjustment. After the peakstreamflow frequency curve parameters were determined, the historically weighted frequency curve was tabulated. If no low outliers, zero flows, or below-gage base peaks were present, Pearson Type III standardized ordinates for the desired skew coefficient and probability were determined and the logarithmic frequency curve ordinates were computed. When peaks below the flood base were present, a conditional frequency curve was determined describing only those peaks above the base. Then, a conditionalprobability adjustment was made to account for the fraction of the population below the flood base.

5. Computation of Weighted Skew Coefficient. The station skew coefficient reflects the average of the cubed deviations from the sample mean and is highly sensitive to the observations in both the upper and lower tails of the sample. The station skew coefficient was combined with the generalized skew, which is a skew coefficient representative of neighboring stations, in a weighted average coefficient that is more accurate than either of its constituents.

6. Expected-Probability Adjustment. The expected probability frequency curve and a set of upper and lower confidence limits were computed. These computations aid the interpretation of the principal, historically weighted frequency curve calculated in the conditional-probability adjustment.

Fitting the Log-Pearson Type III frequency distribution to the logarithms of the annual peak flows required calculating the mean, standard deviation, and skew coefficient of the logarithms of the annual peak-flow series. The mean, standard deviation, and skew coefficient describe the mid-point, slope, and curvature of the peak-flow frequency curve.

Annual exceedance probabilities, the reciprocals of which are recurrence intervals, may be expressed as fractions (or percentages), indicating the likelihood that a particular peak flow may occur. An annual exceedance probability of 1 indicates a 1/1 or 100-percent chance of a particular flow, while an annual exceedance probability of 0.10 indicates a $1 / 10$ or 10 -percent chance of a particular peak flow. Using this terminology, a particular flood-frequency annual exceedance probability may be termed a $\mathrm{P}$-percent chance flow where $\mathrm{P}$ is the probability. Estimates of the annual peak-flow probabilities were computed with program PeakFQ by inserting the three statistics of the frequency distribution into the following equation:

$$
X=\bar{X}+K S,
$$

where

$$
\begin{aligned}
& X=\text { the logarithm of the magnitude of the } \\
& \text { P-percent chance discharge, in cubic feet } \\
& \text { per second; } \\
& \bar{X}=\text { the mean of the logarithms of the annual } \\
& \text { peak streamflows; } \\
& K=\text { the integration factor based on the skew of } \\
& \text { the logarithms and the given P-percent } \\
& \text { chance and is tabulated in Bulletin 17B } \\
& \text { (Interagency Advisory Committee on } \\
& \text { Water Data, 1982); and } \\
& S=\text { the standard deviation of the logarithms and } \\
& \text { is a measure of the variation of the peaks } \\
& \text { about the mean. }
\end{aligned}
$$

Completion of this analytical process resulted in peakflow frequency estimates (table 2). These estimates were based on weighting of the streamgaging station skew and the generalized skew as identified in Plate I of Bulletin 17B (Interagency Advisory Committee on Water Data, 1982).

\section{Basin Characteristics}

Measurements and statistics describing characteristics associated with delineated drainage basins in Virginia were developed and compiled for use as possible explanatory variables in peak-flow regional regression analyses. These basin characteristics describing 312 unique attributes for each of 3,469 delineated drainage basins form a matrix of 1,082,328 values. The basin characteristics were compiled using ArcGIS $^{\text {TM2}}$ and data from the following sources: (1) a Virginia delineated drainage basin dataset (Hayes and Wiegand, 2006); (2) a USGS national hydrography dataset (U.S. Geological Survey, 2006); (3) a Natural Resources Conservation Service (NRCS) soil statistics dataset (U.S. Department of Agriculture, 2007); (4) a PRISM climate dataset (PRISM Climate Group, 2007 ); (5) a National Oceanic and Atmospheric Administration (NOAA) rainfall intensity and climate dataset (National Oceanic and Atmospheric Administration, 2007; Paybins, 2008); (6) a USGS 2005 geology dataset (Dicken and others, 2005); (7) a USGS 2007 national elevation dataset (U.S. Geological Survey, 2007); and (8) a physiography dataset for the United States (Fenneman, 1938). Table 4 (CD in pocket) lists statistics summarizing the basin characteristics that were tested in regional regressions. Descriptions of these basin characteristics, their definitions, and datasources are listed in table 5. Basin characteristics chosen for possible use in candidate regional regression models are listed in table 6 (CD in pocket). Drainage-basin boundaries were obtained

${ }^{2}$ Arc-GIS, ESRI Inc., copyright 1999-2009, ESRI ArcMap 9.3.1 and ArcInfo Workstation GIS software, ESRI Inc., 380 New York Street, Redlands, California 92373-8100. 
from the delineated drainage basin dataset listed above (Hayes and Wiegand, 2006).

\section{Regionalization}

Regional regression analysis was used to develop equations for estimating the magnitude and frequency of peak flows at ungaged sites in Virginia. These equations relate the annual exceedance probability flows computed using floodfrequency analysis to the measured basin characteristics of delineated drainage basins.

Six physiographic regions were used to organize regression analyses of basin characteristics against peak-flow estimates. These six physiographic regions are similar to the five physiographic provinces identified in the discussion of physical setting except that the Mesozoic Basins, considered a subset of the Piedmont Physiographic Province, are identified separately as one of the six physiographic regions. A rationale for this organizational framework, that physiographic differences expressed in these six regions are related to hydrologic response, appeared to be a sound rationale because candidate regression models significantly improved across the range of peak-flow probabilities as a consequence of these regressions based on physiographic regions.

\section{Definition of Regions}

The six regions used to evaluate peak flows are Coastal Plain, Piedmont, Mesozoic Basins, Blue Ridge, Valley and Ridge, and Appalachian Plateaus (fig. 1). Each region was identified using ArcGISTM to perform spatial separations of the geology dataset. Regions were selected and identified iteratively, based on the improved explanatory power of candidate regression models associated with the regions across the range of peak-flow annual exceedance probabilities. The Mesozoic Basins, usually grouped with the Piedmont physiographic region, were explicitly identified as a unique region for the purposes of this study, leading to improved correlations among candidate regional regression models.

\section{Model Development}

Exploratory analyses of all computed annual exceedance probability peak flows and potential explanatory variables (basin characteristics) were performed, prior to developing candidate regression models, using statistical software, JMP ${ }^{\circledR}$ version $8 .{ }^{3}$ Sites with 50 percent or more of their drainage area within a region were included in developing that region's regression equations, with the exception of the Coastal Plain region, in which all sites with 5 percent or more of their drainage area within the region were included in developing the region's regression equations. Of the 476 sites, 52 sites were available in the Coastal Plain, 105 sites were available in the Piedmont, 55 sites were available in the Mesozoic Basins,

${ }^{3}$ SAS Institute Inc., 2009, Cary, North Carolina.
88 sites were available in the Blue Ridge, 157 sites were available in the Valley and Ridge, and 19 sites were available in the Appalachian Plateaus for use in developing regional regression equations. Scatter plots showing relations between pairs of basin characteristics were evaluated along with basic descriptive statistics to (1) identify explanatory variable pairs that are highly correlated with one another so that they may be evaluated and possibly removed from the selection dataset and (2) determine candidate explanatory variable, response variable pairs that are highly correlated with potentially significant explanatory power. In some instances, one or both variables in an explanatory variable, response variable pair were mathematically transformed to potentially enhance their relation and statistical power when part of a linear regression model. Depending on the shape of each scatter plot relation, possible transformations of the $\mathrm{X}$ variable included $\log X, \sqrt{X}, X^{2}$, and $X^{3}$, and possible transformations of the $\mathrm{Y}$ variable included $\log Y, \sqrt{Y}, Y^{2}$, and $Y^{3}$, as suggested by Tukey's bulging rule (Mosteller and Tukey, 1977). Exploratory statistical investigation and comparison of the 312 candidate explanatory basin characteristics associated with each annual exceedance probability peak-flow value proceeded iteratively until each candidate variable, peak-flow value $x-y$ pair was vetted for possible explanatory power.

Candidate regional regression models also were developed following an iterative approach. For each region, and for each peak-flow response variable, forward-, backward-, and mixed-stepwise regressions were used to identify combinations of basin characteristics with likely explanatory power. A list of all possible 1-, 2-, and 3-parameter candidate models was prepared for each peak-flow response variable. The list of candidate models was sorted by the number of explanatory variables in each model. Then, candidate models in each sub-list were evaluated using three metrics - the coefficient of determination (R-square), the root mean square error (RMSE), and Akaike's information criterion (AIC), modified with a second-order correction for small sample sizes and identified as AICc (Burnham and Anderson, 2002). The most reasonable 1-, 2-, and 3-parameter models for each region were chosen as final candidates for regional regression. Final candidate 1-, 2-, and 3-parameter regional regression models were prepared using statistical software (JMP ${ }^{\circledR}$ version 8 ). Explanatory variables for any 2- and 3-parameter models were carefully chosen to ensure that each variable in the model contributed adequate explanatory power and to avoid instances of collinearity, autocorrelation, or excessive variance inflation. Regional regression models were evaluated and modified iteratively. Final models were then selected. Coefficients of final models were specified using the generalized least squares (GLS) option of the Weighted-Multiple-Linear Regression Program (WREG version 1.01; Eng and others, 2009). Preference was given to regional regression models with explanatory variables that are easily determined and understood. Models with little explanatory power and high standard errors were not reported here. All final models, specified using GLS, are 1-parameter models. 


\section{Model Verification and Diagnostics}

Evaluation of candidate models using R-square, RMSE, and AICc provided insights into the most appropriate candidate model choices for each peak-flow response variable in each region. The $\mathrm{R}$-square value indicated the proportion of variability in each relation that was accounted for by the statistical model - in this case, a linear regression model. R-square values approaching 1 suggest increased explanatory power. The RMSE value indicated the differences between values predicted by each model and the values actually observed or measured. The RMSE helped to aggregate individual residual differences into a single measure of predictive power. To assist in choosing among candidate models in each region, plots were constructed identifying each candidate model by the number of model parameters (x-axis) and RMSE value (y-axis), providing a spatial representation of increased or decreased RMSE relative to the number of model terms. The AICc value indicated the goodness of fit of each regression model, relative to other candidate models in the list, providing a tool for model selection. AICc values are grounded in the concept of entropy, offering a relative measure of the information lost when a given model is used to describe reality. AICc describes the difference between model bias and model variance, or the tradeoff between model precision and model complexity. Several competing models were ranked by their AICc values. Lower AICc values were considered better than higher values.

Leverage plots (Sall, 1990), also known as "partialregression residual leverage plots" (Belsley and others, 1980) or "added variable plots" (Cook and Weisberg, 1982), were used to further investigate and screen candidate regional regression models. Leverage plots allow one to view the significance of each model parameter in the candidate regression model within the context of the larger model. The effect of a model parameter on the larger model is displayed on the leverage plot by comparing the sum of squared residuals of the model to the sum of squared residuals of the model with the effect of interest removed. Residual errors that are smaller when the effect of a particular parameter is included in the model help confirm that the effect contributes significantly to the model fit. The leverage plot graphically displays this potential significance for each candidate explanatory variable in each candidate model, showing for each point in the model what the residual would be with and without the effect of the explanatory variable in the model. In the leverage plot, the distance from a point to the line of fit describes the actual residual. The distance from a point to the horizontal line of the mean describes the potential residual error if the effect were not part of the model. In other words, the mean line of the leverage plot represents the model if the value of the parameter effect were constrained to zero. The idea is to determine if the line of fit on the leverage plot for each explanatory variable carries each point on the plot significantly better than does the horizontal line of the mean shown on the plot. Leverage plots were used to identify (1) regression variables with significant explanatory power, (2) regression variables with borderline or insignificant explanatory power, and (3) regression variables exhibiting significant collinearity within the model (fig. 2).
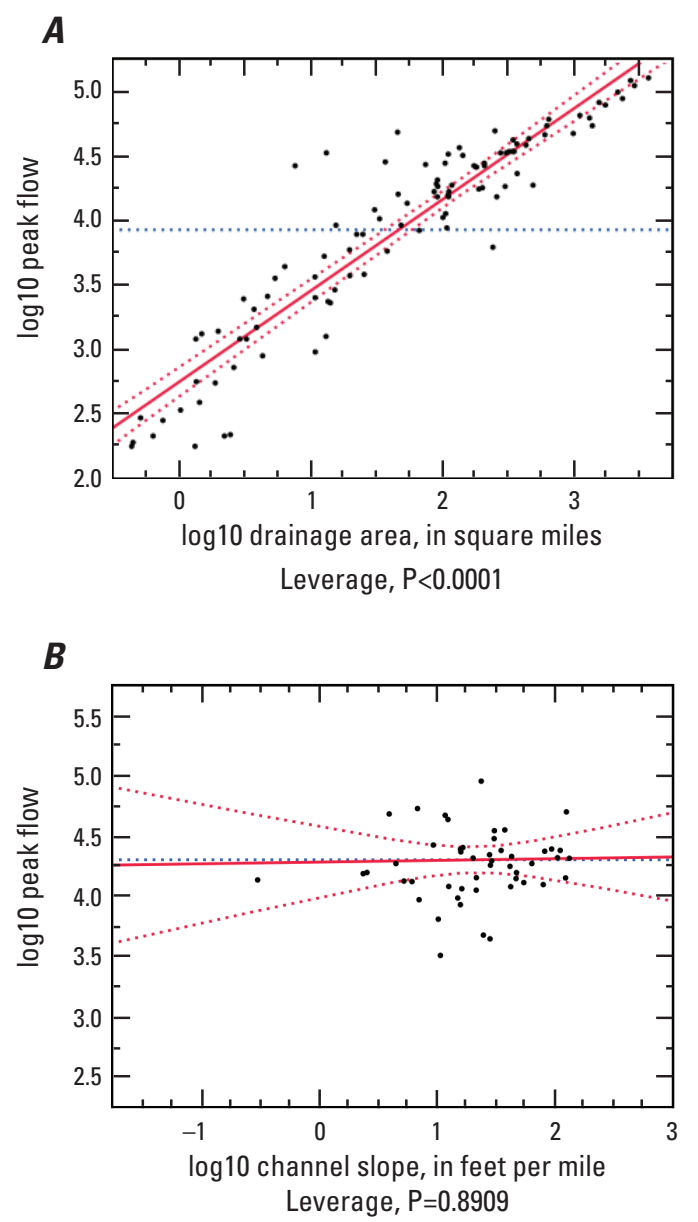

C

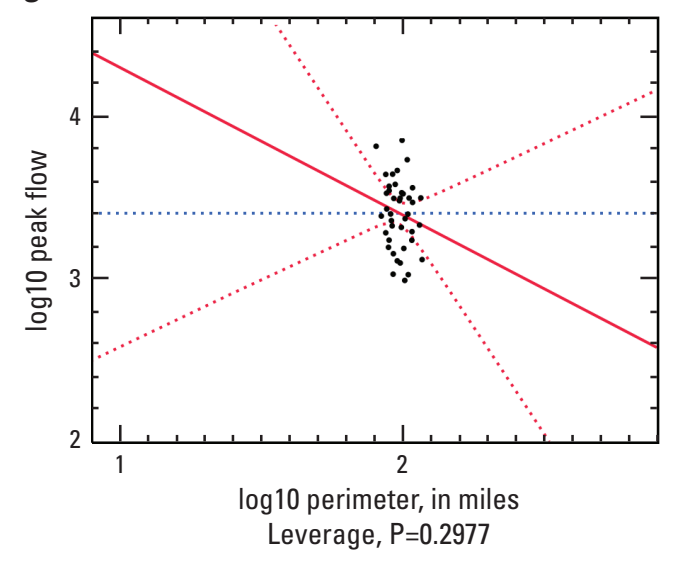

Figure 2. Example leverage plots showing $(A)$ significant explanatory power, $(B)$ insignificant explanatory power, and (C) evidence of collinearity. The solid red lines represent the significance of each explanatory model parameter, shown on the $x$-axis, within the context of the larger model. The dashed red lines represent the confidence interval of the significance of each explanatory model parameter. The dashed blue lines represent the horizontal line of the mean, describing the larger model if the effect of each explanatory model parameter were constrained to zero. The idea behind each leverage plot is to determine if the line of fit for each potential explanatory model variable carries each point on the plot significantly better than does the horizontal line of the mean shown on the plot. 
Analyses of leverage plots for each potential explanatory variable in a candidate regression model afforded the opportunity to see the characteristics of each candidate variable, the influential strength of the variable, and its consequences within the larger model. The picture provided by each leverage plot enabled a thorough, visual vetting of individual candidate model variables and a measure of confidence in variable selection that could not be obtained from non-graphical indices of collinearity and variable inflation, preparing a means to construct robust regional regressions. A leverage plot was constructed and evaluated for each model parameter in each candidate regional regression model. Iterative comparisons of models were made, and the stronger models were selected as final candidates. Models containing explanatory variables with significant explanatory power, limited parameter counts, and limited collinearity were preferred as final candidates.

Explanatory variables associated with the best candidate models were chosen for inclusion in final candidate singleparameter and multi-parameter regional regression models. Preference was given to explanatory variables that are easily measured and understood.

Final models were specified using GLS regression as described by Stedinger and Tasker (1985) and Tasker and Stedinger (1989). Candidate regional regressions and their associated leverage plots were carefully evaluated to avoid the effects of potential cross correlation between sites and excessive variability in peak flows at streamgaging stations.

Because the length of streamflow record varies among stream gages, the precision of streamflow estimates also varies. Different streamflow records have different variances. Peak flows at streamgaging stations within a particular region are at risk of being correlated with other peak flows in the region due to atmospheric conditions that may cause temporally coincident flood peaks. The concurrent flows observed at different gages in a region can yield cross correlations. If these correlations are not accounted for in a regional analysis, regression parameters may be less precise, and estimators of precision may be less accurate (Eng and others, 2009).

GLS analyses account for cross correlations among these characteristics. In GLS analyses, weights are formed using the period of record and the variance of the response variable annual time series. The series of annual peaks at streamgaging stations and the geographic distances between streamgages are examined to help determine the degree of potential correlation between sites. Weights are assigned to account for variability. Sites exhibiting potentially cross-correlated concurrent peak flows are given less weight than other sites. Pseudo R-square is reported for each GLS regression model. A metric in the style of the R-square commonly reported as part of ordinary least squares regression, pseudo R-square is designed specifically to evaluate the iterative models developed using GLS.

The average variance of prediction (AVP; Stedinger and Tasker, 1985; Tasker and Stedinger, 1989) is a helpful indication of the average error of a GLS regression. The AVP may be represented by one of two equations. The first option is

$$
A V P=\sigma_{i}^{T}+\left(\frac{1}{n}\right) \sum_{n=1}^{n} x_{1}\left(X^{T} \wedge X\right)^{-1} X_{i}^{T}
$$

where

$$
\begin{aligned}
A V P= & \text { the average variance of prediction; } \\
\sigma_{i}^{T}= & \text { the model error variance; } \\
n & =\text { the number of stations in the regression } \\
& \text { model; }
\end{aligned}
$$

The second option is

$$
A V P=\text { error }_{m}+\text { error }_{t},
$$

where

$$
\begin{aligned}
A V P & =\text { the average variance of prediction; } \\
\text { error }_{m} & =\text { model error; and } \\
\text { error }_{t} & =\text { time sampling error. }
\end{aligned}
$$

The AVP may be used to provide an estimate of errors that may be associated with the use of a regression model to estimate flow statistics at an ungaged site. An important consideration is that the AVP metric assumes that basin characteristics at the ungaged location are similar to those used to develop the model.

The average standard error of prediction in percent, $S_{p}$, is used in this report to express the AVP as a percentage. $S_{p}^{p}$ is computed from the AVP (Aitchison and Brown, 1957) and modified for use with common logarithms as follows:

$$
S_{p}=100 \sqrt{\operatorname{EXP}\left[\sigma^{2} \bullet \ln (10)^{2}\right]}-1,
$$

where

$$
\begin{gathered}
S_{p}=\text { the average standard error of prediction, in } \\
\text { percent; and } \\
\sigma^{2}=\text { the average variance of prediction. }
\end{gathered}
$$

\section{Weighting Multiple Estimates}

Weighting techniques often improve regional flow estimates. This is true of peak-flow estimates, which may be 
improved by computing a weighted average of two independent estimates: (1) an estimate made by fitting a Log-Pearson Type III distribution to data using peak-flow analysis, and (2) an estimate made by developing a regional regression equation describing station peak flow.

\section{Weighting of Independent Estimates}

Methods described in Appendix 8 of Bulletin 17B (Interagency Advisory Committee on Water Data, 1982) were used to calculate a weighted estimate and variance at each peak-flow station using information from flood-frequency analysis and a corresponding regional regression equation. The equations developed by Gilroy were used to determine the weighted discharge and variance of peak flow at each station. The recommended procedure assumes that the two peak-flow estimates are independent, which, as noted in Bulletin 17B, is true in most practical situations (Interagency Advisory Committee on Water Data, 1982, p. 8-1; Cohn and others, 2001; Berenbrock, 2002).

The idea is that if two independent estimates are weighted in inverse proportion to their variances, then the variance of the weighted average is less than the variance of either estimate. This is accomplished using the following equations (Interagency Advisory Committee on Water Data, 1982):

$$
Z=\frac{x\left(V_{y}\right)+y\left(V_{x}\right)}{V_{y}+V_{x}}
$$

and

$$
V_{z}=\frac{V_{x} V_{y}}{V_{x}+V_{y}},
$$

where

$$
\begin{array}{cc}
x=\text { a first independent estimate of peak flow; } \\
y=\text { a second independent estimate of peak flow; } \\
Z=\text { a weighted average estimate of peak flow; } \\
V_{x}=\text { variance of a first independent estimate of } \\
\quad \text { peak flow; } \\
V_{y}=\begin{array}{c}
\text { variance of a second independent estimate of } \\
\text { peak flow; and }
\end{array} \\
V_{z}=\begin{array}{c}
\text { variance of a weighted average estimate of } \\
\text { peak flow. }
\end{array}
\end{array}
$$

Using the procedures described in Bulletin 17B and equations 5 and 6 , peak-flow estimates determined using Log-Pearson Type III frequency analysis (table 2) were used with peak-flow estimates determined by the regional regression equations (table 3 ) to yield weighted peak-flow estimates (table 2). As the number of years of record becomes large, the weighted peak-flow estimate approaches the station peak-flow estimate.

\section{Peak-Flow Characteristics}

Peak-flow characteristics describe the magnitude and frequency of peak flows, providing insights into the dynamics and variability of water movement through stream systems. They offer a basis for evaluating risk and analyzing streamflow response to changes in ecosystem and climate. Peak-flow characteristics are listed in table 2. Table 2 lists peak-flow values determined by flood-frequency analysis as outlined in Bulletin 17B, in which a Log-Pearson Type III frequency distribution is fitted to the logarithms of annual peak flows. These values were calculated using program PeakFQ (Flynn and others, 2006).

Table 3 lists peak-flow regional regression equations of the final models. Candidate single- and multi-parameter equations were developed to determine annual exceedance probability peak flows for each of six regions. Single-parameter equations describing annual exceedance probability peak flow as a function of basin drainage area (DA) were found to be superior to multi-parameter regional regression equations, combining explanatory power, an easily measured explanatory variable (DA), ease of interpretation and use, and lower risks of explanatory variable inflation or collinearity.

Table 2 also lists peak-flow values computed from the regional regression equations listed in table 3 and peak-flow values determined by weighting the independent Log-Pearson Type III peak-flow estimates listed in table 2 with those computed from the equations in table 3.

For a gaged site, the most reliable estimates of peak-flow probabilities are generally provided by the values listed in table 2 developed from fitting a Log-Pearson Type III frequency distribution to the logarithms of the annual peak flows. Weighted peak-flow probabilities listed in table 2 may be used when circumstances suggest that a weighted estimate may be helpful, combining Log-Pearson Type III fitted values and estimates from regional regression equations.

\section{Other Methods for Estimation at Ungaged Sites}

For an ungaged site, the appropriate method for calculating peak-flow estimates depends on whether (1) the drainage basin lies within a single peak-flow region, (2) the drainage area crosses peak-flow regional boundaries, or (3) the ungaged site is located on a gaged stream.

Peak-flow estimates at sites on ungaged streams that lie entirely within a single peak-flow region may be calculated using the regional regression equations listed in table 3.

Peak-flow estimates at sites with drainage basins that cross peak-flow regional boundaries may be made by first determining the percentage of the basin in each region. Peakflow estimates are then computed for the entire basin drainage area by using the appropriate equation for each peak-flow 
region, then multiplying the peak flow for each part of the basin by the percentage of the entire basin in that region, and summing the contributions from each peak-flow region.

Peak-flow estimates at an ungaged site located on a gaged stream, where the drainage area of the ungaged site is between 50 and 150 percent of the drainage area at the gaged site, may be adjusted using the following method (Hannum, 1976; Glatfelter, 1984; Bisese, 1995).

1. Estimate the peak flow at the ungaged site using one of the methods previously described.

2. Compute a correction factor for the gaged site as follows:

$$
C_{g}=\frac{Q_{(p) w(\text { gaged })}}{Q_{(p) r(\text { gaged })}},
$$

where

$$
\begin{aligned}
C_{g}= & \text { the correction factor for the gaged site; } \\
Q_{(p) w(g a g e d)}= & \text { the weighted peak-flow estimate at the gaged } \\
& \text { site for exceedance probability, } p, \text { from } \\
& \text { table } 2 \text { and } \\
Q_{(p) r(\text { gaged })}= & \text { the regional regression peak-flow estimate at } \\
& \text { the gaged site for exceedance probability, } \\
& \text {, computed from the equations listed in } \\
& \text { table } 3 .
\end{aligned}
$$

3. Compute a correction factor for the ungaged site as follows:

$$
C_{u}=C_{g}-\left(\frac{2\left|A_{g}-A_{u}\right|}{A_{g}}\right)\left(C_{g}-1\right),
$$

where

$C_{u}=$ the correction factor for the ungaged site;

$C_{g}=$ the correction factor for the gaged site, from the previous equation;

$A_{g}=$ the drainage area at the gaged site;

$A_{u}=$ the drainage area at the ungaged site; and

$\left|A_{g}-A_{u}\right|^{\prime}=$ the absolute value of the difference between the drainage area of the gaged site and the drainage area of the ungaged site.

4. Estimate the adjusted peak flow at the ungaged site as follows:

$$
Q_{(p) a(\text { ungaged })}=C_{u} Q_{(p) r(\text { ungaged })},
$$

where

$$
\begin{array}{ccc}
C_{u}=\begin{array}{c}
\text { correction factor ratio from the previous } \\
\text { equation; }
\end{array} \\
\begin{array}{c}
\text { adjusted peak-flow estimate for the ungaged } \\
\text { site for flow probability, } p \text {; and }
\end{array} \\
\begin{array}{c}
\text { regression peak-flow estimate for the } \\
\text { ungaged site for flow probability, } p .
\end{array}
\end{array}
$$

As the difference in drainage area between the gaged and ungaged sites approaches 50 percent or 150 percent of the drainage area of the gaged site, the correction factor for the ungaged site approaches 1 , and the adjusted value approaches the regression estimate for the ungaged site.

\section{Examples of Calculating Peak-Flow Estimates}

The following four exercises provide step-by-step examples of how to perform calculations and apply the methods suggested in this report to estimate peak flows. Example calculations are shown for estimating peak flows by (1) using the regression equations provided in this report, (2) using the drainage-area ratio method when a drainage basin spans two or more peak-flow regions, (3) using a nearby gage for an ungaged site, and (4) using a gaged site.

\section{Use of Regression Equations}

Example 1. Estimating 0.02-probability (50-year) peak flow at an ungaged site on a stream with a drainage basin completely contained within the Valley and Ridge region.

Given: Drainage area (DA) of $0.80 \mathrm{mi}^{2}$ for this basin, measured from a 1:24,000-scale topographic map.

Solution: The regression estimate for the site is computed using the appropriate equation in table 3 for the 0.02 -probability (50-year) discharge within the Valley and Ridge region as follows:

$$
\begin{aligned}
& \log 10\left(\mathrm{Q}_{(0.02)}\right)=2.862+0.626 \bullet \log 10(0.80) \\
& \log 10\left(\mathrm{Q}_{(0.02)}\right)=2.801 \\
& \mathrm{Q}_{(0.02)}=10^{2.801}=633 \text { cubic feet per second. }
\end{aligned}
$$

\section{Drainage-Area Ratio Method}

Example 2. Estimating the 0.01-probability (100-year) peak flow at an ungaged site on a stream with a drainage basin that spans the Piedmont and Blue Ridge regions. 


\section{Given:}

1. Drainage area (DA) of $7.6 \mathrm{mi}^{2}$ for the entire basin, measured from a 1:24,000-scale topographic map.

2. Thirty-seven percent of the basin is located in the Piedmont region, and the remaining 63 percent of the basin lies within the Blue Ridge region.

Solution: Calculate the 0.01-probability (100-year) peak flow for the basin using the Piedmont and Blue Ridge regional regression equations from table 3 , then multiply each by the fraction of the drainage area in each region to compute a final estimate, as follows:

For the Piedmont region:

$\log 10\left(\mathrm{Q}_{(0.01 \text { Piedmont })}\right)=3.157+0.490 \bullet \log 10(7.6)=3.589$

$\mathrm{Q}_{(0.01 \text { Piedmont })}=10^{3.589}=3,878$ cubic feet per second.

For the Blue Ridge region:

$\log 10\left(\mathrm{Q}_{(0.01 \text { Blue Ridge })}\right)=3.184+0.593 \bullet \log 10(7.6)=3.706$

$\mathrm{Q}_{(0.01 \text { Blue Ridge })}=10^{3.706}=5,085$ cubic feet per second.

The combined estimate for the basin:

$\left.\mathrm{Q}_{(0.01 \text { combined })}=(3,878 \bullet 0.37)+5,085 \bullet 0.63\right)$

$=4,639$ cubic feet per second.

\section{Ungaged Site with Nearby Gage}

Example 3. Estimating the 0.10-probability (10-year) peak flow at an ungaged site on the New River, located upstream from New River streamgage number 03164000 near Galax, Virginia, in the Blue Ridge region.

\section{Given:}

1. Drainage area $\left(A_{u}\right)$ of $275 \mathrm{mi}^{2}$ for the basin above the ungaged site, measured from a 1:24,000-scale topographic map.

2. Drainage area $\left(A_{g}\right)$ of $1,141 \mathrm{mi}^{2}$ for the basin above the gaged site, from table 2.

Solution: The drainage area of the ungaged site is 24 percent of the drainage area at the gaged site. Using eq 7, the correction factor ratio for the gaged site $\left(C_{g}\right)$ is 0.992 .

The correction factor ratio for the ungaged $\left(C_{u}\right)$ site is determined using eq 8 and is 1.004 .
Estimate the adjusted peak flow at the ungaged site as follows (eq 9):

$$
\begin{aligned}
& Q_{(p) a(\text { ungaged })}=C_{u} Q_{(p) r(\text { ungaged })}, \\
= & 1.004 \cdot 10 \text { (equation result from table } 3 \text { for } \\
& \text { the ungaged site as a superscript) } \\
= & 1.004 \cdot 10^{4.267} \\
= & 18,577 \text { cubic feet per second. }
\end{aligned}
$$

\section{Gaged Site}

Example 4. Estimating the 100-year peak-flow at a gaged site on the North Fork of the Rivanna River at Route 606 near Earlysville, Virginia (station number 02032640).

Given: Because this is a gaged site, the 100 -year peak-flow may be read directly from table 2 (Peak-flow frequency estimates for streamgaging stations in Virginia).

Solution: In table 2, find station number 02032640 in the left hand column, identifying the gage on the North Fork of the Rivanna River at Route 606 near Earlysville, Virginia. Read across to find the peak-flow discharge of 49,710 cubic feet per second ( $\left.\mathrm{ft}^{3} / \mathrm{s}\right)$ corresponding to the annual exceedance probability of 0.01 (100-year recurrence interval): $\mathrm{Q}_{(100)}=49,710 \mathrm{ft}^{3} / \mathrm{s}$.

\section{Summary}

Understanding peak water flows in Virginia streams is essential to human safety and sound management of water resources and associated riparian and watershed ecosystems. Meaningful characterizations of the magnitude and frequency of peak flows provide valuable insights into the dynamics and variability of water movement through these unique stream systems. This report summarizes a statistical analysis of peak-flow data collected in Virginia from 1895 through 2007. Peak-flow values for annual exceedance probability estimates of $0.5,0.4292,0.2,0.1,0.04,0.02,0.01,0.005$, and 0.002 are summarized for 476 streamgaging stations, and regression equations organized by physiographic region are presented for estimating annual exceedance probability peak flows using basin characteristics.

Streamgaging stations with at least 10 years of peak-flow record were identified as study candidates. All of these streamgaging stations were considered, including those in predominately urban and predominately rural basins. Data from each candidate streamgaging station were quality checked to identify numerical errors. Each list of datapoints was individually evaluated to discover and segregate intervals in the record 
in which concomitant effects such as data of poor quality or severely altered or regulated flows negatively affected the candidate data. Remaining datapoints in each dataset were evaluated for evidence of trends. Statistics were generated to identify monotonic, non-monotonic, linear, and non-linear correlation, including (1) Kendall's Tau, (2) an index of Kendall's trend probability, and (3) Spearman's rho. Other statistical analyses performed include (4) calculating and plotting a linear regression of each dataset with time, (5) plotting residuals to help identify any significant correlation or autocorrelation, and (6) performing runs tests to identify non-linear change over time. Of the 589 candidate datasets considered for study, 113 were removed from consideration because they either had too few datapoints available for analysis, or they characterized streams with excessively regulated flow. Thirty-five of the remaining 476 sites were partially censored prior to analysis due to indications of excessively regulated flow or peak flows measured below the gage base.

Regional regression analyses of peak-flow response associated with explanatory basin characteristics provide insights into the nature of peak flows across Virginia. Regional regression equations describing peak flow as a function of basin drainage area are identified within each of the six physiographic regions delineated for study. Regression equations describing peak-flow annual exceedance probability as a function of basin drainage area in the Coastal Plain, Piedmont, Mesozoic Basins, Blue Ridge, Valley and Ridge, and Appalachian Plateaus physiographic regions yielded median pseudo R-square values of $0.87,0.91,0.81,0.94,0.88$, and 0.88 , respectively. These same equations yielded median standard error of prediction values of 58 percent, 37 percent, 43 percent, 28 percent, 31 percent, and 0.34 percent, and median standard model error values of 53 percent, 35 percent, 40 percent, 26 percent, 29 percent, and 0.31 percent, respectively. Pseudo R-square is used to evaluate the final models developed using GLS. The standard error of prediction expresses AVP as a percentage of the predicted value. The standard model error expresses variance in model accuracy as a percentage of the predicted value. Four example calculations are presented in the report as an aid in applying recommended methods for estimating peak flows at ungaged sites, including the use of regional regression model equations. Results of this study supersede published results in previous studies of peak flows in Virginia.

\section{Acknowledgments}

The authors extend their thanks to the Virginia Department of Transportation, whose continued collaboration and assistance, especially with collection and compilation of peak-flow data for Virginia streams, made this report possible.

We also extend special thanks to the following individuals for their exceptional and energetic guidance, work, advice, review, and editing as information was compiled and this report was prepared: Donald C. Hayes, George E. Harlow, Jr., Theodore B. Samsel, and Robert B. Banks of the U.S. Geological Survey.

\section{References}

Aitchison, J., and Brown, J.A.C., 1957, The lognormal distribution, with special reference to its uses in economics: Cambridge, U.K., Cambridge University Press, 176 p.

Belsley, D.A., Kuh, E., and Welsch, R.E., 1980, Regression diagnostics: New York, John Wiley and Sons, 292 p.

Benson, M.A., 1962, Factors influencing the occurrence of floods in a humid region of diverse terrain: U.S. Geological Survey Water-Supply Paper 1580-B, 64 p.

Benson, M.A., 1964, Factors affecting the occurrence of floods in the southwest: U.S. Geological Survey Water-Supply Paper 1580-D, $72 \mathrm{p}$.

Berenbrock, C., 2002, Estimating the magnitude of peak flows at selected recurrence intervals for streams in Idaho: U.S. Geological Survey Water-Resources Investigations Report 02-4170, $59 \mathrm{p}$.

Bisese, J.A., 1995, Methods for estimating magnitude and frequency of peak discharges of rural, unregulated streams in Virginia: U.S. Geological Survey Water-Resources Investigations Report 94-4148, 70 p.

Burnham, K.P., and Anderson, D.R., 2002, Model selection and inference-A practical information-theoretic approach: New York, Springer-Verlag, 488 p.

Cohn, T.A., Lane, W.L., and Stedinger, J.R., 2001, Confidence intervals for expected moments algorithm flood quantile estimates: Water Resources Research, v. 37, no. 6, p. 16951706.

Cook, R.D., and Weisberg, S., 1982, Residuals and influence in regression: New York, Chapman and Hall, 229 p.

Cushing, E.M., Kantrowitz, I.H., and Taylor, K.R., 1973, Water resources of the Delmarva Peninsula: U.S. Geological Survey Professional Paper 822, 58 p. 
Dicken, C.L., Nicholson, S.W., Horton, J.D., Kinney, S.A., Gunther, G., Foose, M.P., and Mueller, J.A.L., 2005, Preliminary integrated geologic map databases for the United States-Delaware, Maryland, New York, Pennsylvania, and Virginia: U.S. Geological Survey Open-File Report 2005-1325, 48 p. (Also available at http://pubs.usgs. gov/of/2005/1325/.)

Dillow, J.A., 1996, Technique for estimating magnitude and frequency of peak flows in Maryland: U.S. Geological Survey Water-Resources Investigations Report 95-4154, 55 p.

Edwards, L.E., Barron, J.A., Bukry, David, Bybell, L.M., Cronin, T.M., Poag, C.W., Weems, R.E., and Wingard, G.L., 2005, Paleontology of the upper Eocene to Quaternary postimpact section in the USGS-NASA Langley core, Hampton, Virginia, chap. H of Horton, J.W., Jr., Powars, D.S., and Gohn, G.S., eds., Studies of the Chesapeake Bay impact structure-The USGS-NASA Langley corehole, Hampton, Virginia, and related coreholes and geophysical surveys: U.S. Geological Survey Professional Paper 1688, p. H1-H47, 9 fossil plates, 2 oversize figures.

Eng, Ken, Chen, Y.-Y., and Kiang, J.E., 2009, User's guide to the weighted-multiple-linear regression program (WREG version 1.0): U.S. Geological Survey Techniques and Methods, book 4, chap. A8, 21 p., accessed March 3, 2011, at http://pubs.usgs.gov/tm/tm4a8/.

Fenneman, N.M., 1938, Physiography of Eastern United States: New York, McGraw-Hill, 714 p.

Fenneman, N.M., and Johnson, D.W., 1946, Physiographic divisions of the conterminous U.S.: U.S.Geological Survey map product, scale 1:7,000,000. (Also available at $h t t p: / /$ water.usgs.gov/GIS/metadata/usgswrd/XML/physio.xml.)

Fichter, L.S., and Baedke, S.J., 1999, A description of the geology of Virginia, accessed June 22, 2010, at $h t t p: / /$ csmres.jmu.edu/geollab/vageol/vahist/PhysProv.html.

Flynn, K.M., Kirby, W.H., and Hummel, P.R., 2006, User's manual for program PeakFQ annual flood-frequency analysis using Bulletin 17B guidelines: U.S. Geological Survey Techniques and Methods, book 4, chap. B4, 42 p.

Glatfelter, D.R., 1984, Techniques for estimating magnitude and frequency of floods in Indiana: U.S. Geological Survey Water-Resources Investigations Report 84-4134, 110 p.

Hannum, C.H., 1976, Techniques for estimating magnitude and frequency of floods in Kentucky: U.S. Geological Survey Water-Resources Investigations Report 76-62, 70 p.

Hayes, D.C., 1991, Low-flow characteristics of streams in Virginia: U.S. Geological Survey Water-Supply Paper 2374, $69 \mathrm{p}$.
Hayes, D.C., and Nelms, D.L., 2001, Base-flow characteristics of streams in the Valley and Ridge, Blue Ridge, and Piedmont physiographic provinces of Virginia and other mid-Atlantic States [abs.], in Adams, D.B., Burke, Katrina, Hemingway, Bruce, Key, Jeff, and Yurewicz, Michael, comps., U.S. Geological Survey Appalachian Region Integrated Science Workshop proceedings, Gatlinburg, Tennessee, October 22-26, 2001: U.S. Geological Survey OpenFile Report 01-406, p. 87-88.

Hayes, D.C., and Wiegand, U., 2006, Drainage areas of selected streams in Virginia: U.S. Geological Survey OpenFile Report 2006-1308, 51 p.

Hayes, D.C., and Young, R.L., 2005, Comparison of peak discharge and runoff characteristic estimates from the rational method to field observations for small basins in central Virginia: U.S. Geological Survey Scientific Investigations Report 2005-5254, 44 p.

Helsel, D.R., and Hirsch, R.M., 2002, Statistical methods in water resources: U.S. Geological Survey Techniques of Water-Resources Investigations Report, book 4, chap. A3, $510 \mathrm{p}$.

Hirsch, R.M., Slack, J.R., and Smith, R.A., 1982, Techniques of trend analysis for monthly water quality data: Water Resources Research, v. 18, no. 1, p. 107-121.

Homer, C., Huang, C., Yang, L., Wylie, B., and Coan, M., 2004, Development of a 2001 National Land-Cover Database for the United States: Photogrammetric Engineering and Remote Sensing, v. 70, no. 7, p. 829-840.

Interagency Advisory Committee on Water Data, 1982, Guidelines for determining flood flow frequency: Water Resources Council Bulletin 17B, 28 p.

Jennings, M.E., and Benson, M.A., 1969, Frequency curves for annual flood series with some zero events or incomplete data: Water Resources Research, v. 5, no. 1, p. 276-280.

Kirby, W., 1980, Computer routines for probability distributions, random numbers, and related functions: U.S. Geological Survey Open-File Report 80-448, 61 p.

Lane, E.W., and Lei, K., 1950, Stream flow variability: Transactions of the American Society of Civil Engineers, v. 115, p. 1084-1134.

Langbein, W.B., and Iseri, K.T., 1995, General introduction and hydrologic definitions, manual of hydrology—Part 1. General surface-water techniques: U.S. Geological Survey Water-Supply Paper 1541-A, 29 p. (Also available at $h t t p: / /$ water.usgs.gov/wsc/glossary.html.) 
Lumb, A.M., Kittle, J.L., Jr., and Flynn, K.M., 1990, Users manual for ANNIE, computer program for interactive hydrologic analysis and data management: U.S. Geological Survey Water-Resources Investigations Report 89-4080, $236 \mathrm{p}$.

Lynch, D.D., 1987, Hydrologic conditions and trends in Shenandoah National Park, Virginia: U.S. Geological Survey Water-Resources Investigations Report 87-4131, 115 p.

Miller, E.M., 1969, Floods in Virginia, magnitude and frequency: U.S. Geological Survey Open-File Report, 54 p.

Miller, E.M., 1978, Technique for estimating magnitude and frequency of floods in Virginia: U.S. Geological Survey Water-Resources Investigations Report 78-5, 83 p.

Mixon, R.B., Berquist, C.R., Jr., Newell, W.L., Johnson, G.H., Powars, D.S., Schindler, J.S., and Rader, E.K., 1989, Geologic map and generalized cross sections of the Coastal Plain and adjacent parts of the Piedmont, Virginia with generalized geologic cross sections: U.S. Geological Survey Miscellaneous Investigations Map I-2033, scale 1:250,000.

Mosteller, F., and Tukey, J.W., 1977, Data analysis and regression-A second course in statistics: Reading, Massachusetts, Addison-Wesley, 588 p.

National Oceanic and Atmospheric Administration, 2007, National Weather Service Hydrometeorological Design Studies Center, precipitation frequency data server, accessed January 27, 2009, at http://dipper.nws.noaa.gov/hdsc/pfds/.

Nelms, D.L., Harlow, G.E., Jr., and Hayes, D.C., 1997, Baseflow characteristics of streams in the Valley and Ridge, the Blue Ridge, and the Piedmont Physiographic Provinces of Virginia: U.S. Geological Survey Water-Supply Paper 2457, 48 p., 1 pl.

Nuckels, E.H., 1970, Virginia streamflow data program analysis: U.S. Geological Survey Open-File Report, 54 p.

Paybins, K.S., 2008, Basin characteristics for selected streamflow-gaging stations in and near West Virginia: U.S. Geological Survey Open-File Report 2008-1087, 9 p. (Also available at $h t t p: / / p u b s . u s g s . g o v / o f / 2008 / 1087 /$.

PRISM Climate Group, Oregon State University, 2007, Mean annual precipitation from 1971 to 2000 and average monthly rainfall for January, February, and March, accessed May 5, 2008, at http://prism.oregonstate.edu/products/ matrix.phtml.

Prugh, B.J., Jr., Nuckels, E.H., and Humphreys, C.G., 1991, Annual maximum stages and discharges of selected streams in Virginia through 1990: U.S. Geological Survey Open-File Report 90-587, 442 p.
Ries, K.G., III, and Friesz, P.J., 2000, Methods for estimating low-flow statistics for Massachusetts streams: U.S. Geological Survey Water-Resources Investigations Report 00-4135, $81 \mathrm{p}$.

Sall, J., 1990, Leverage plots for general linear hypotheses: The American Statistician, v. 44, no. 4, p. 308-315.

Smith, R.W., 1981, Rock type and minimum 7-day/10-year flow in Virginia streams: Virginia Water Resources Research Center Bulletin 116, 43 p.

Speer, P.R., and Gamble, C.R., 1964a, Magnitude and frequency of floods in the United States-Part 2A, South Atlantic slope basins, James River to Savannah River: U.S. Geological Survey Water-Supply Paper 1673, 329 p.

Speer, P.R., and Gamble, C.R., 1964b, Magnitude and frequency of floods in the United States-Part 3B, Cumberland and Tennessee River basins: U.S. Geological Survey Water-Supply Paper 1676, $340 \mathrm{p}$.

Speer, P.R., and Gamble, C.R., 1965, Magnitude and frequency of floods in the United States-Part 3A, Ohio River basin except Cumberland and Tennessee River basins: U.S. Geological Survey Water-Supply Paper 1675, 630 p.

Stedinger, J.R., and Tasker, G.D., 1985, Regional hydrologic analysis 1 - Ordinary, weighted, and generalized least squares compared: Water Resources Research, v. 21, no. 9, p. 1421-1432.

Stedinger, J.R., and Thomas, W.O., Jr., 1985, Low-flow frequency estimation using base-flow measurements: U.S. Geological Survey Open-File Report 85-95, 22 p.

Tasker, G.D., 1975, Combining estimates of low-flow characteristics of streams in Massachusetts and Rhode Island: Journal of Research of the U.S. Geological Survey, v. 3, no. 1, p. 107-112.

Tasker, G.D., and Stedinger, J.R., 1989, An operational GLS model for hydrologic regression: Journal of Hydrology, v. 111, p. 361-375.

The College of William \& Mary Department of Geology, 2010, The geology of Virginia, accessed June 22, 2010, at http://web.wm.edu/geology/virginia/.

Tice, R.H., 1954, Magnitude and frequency of floods in the Shenandoah Valley of Virginia: U.S. Geological Survey Open-File Report, 33 p.

Trainer, F.W., and Watkins, F.A., Jr., 1975, Geohydrologic reconnaissance of the upper Potomac River basin: U.S. Geological Survey Water-Supply Paper 2035, 68 p. 
U.S. Department of Agriculture, 2007, U.S. General Soil Map (STATSGO2) for Virginia, prepared by the soil survey staff of the Natural Resources Conservation Service, accessed during 2007 at http://soildatamart.nrcs.usda.gov.

U.S. Geological Survey, 2006, National hydrologic dataset, accessed during 2007 at http://nhdgeo.usgs.gov/viewer.htm.

U.S. Geological Survey, 2007, National elevation dataset, accessed during 2007 at http://seamless.usgs.gov.
Wetzel, K.L., and Bettandorff, J.M., 1986, Techniques for estimating streamflow characteristics in the eastern and interior coal provinces of the United States: U.S. Geological Survey Water-Supply Paper 2276, 80 p.

Yang, L., Huang, C., Homer, C.G., Wylie, B.K., and Coan, M.J., 2002, An approach for mapping large-area impervious surfaces - Synergistic use of Landsat 7 ETM+ and high spatial resolution imagery: Canadian Journal of Remote Sensing, v. 29, no. 2, p. 230-240. 


\section{Glossary}

[Unless otherwise noted, definitions are based on Langbein, W.B., and Iseri, K.T, 1995, Hydrologic definitions, available at USGS Web site http://water.usgs.gov/wsc/glossary.html]

Bankfull stage The elevation at which the active channel meets the actively forming floodplain in the current climatic regime. It is the stage at which the stream first overflows its natural banks formed by floods with 1- to 3-year recurrence intervals.

Cubic feet per second $\left(\mathrm{ft}^{3} / \mathbf{s}\right) \quad$ A measure of the rate of water discharge representing a volume of 1 cubic foot of water passing a given point in 1 second.

Discharge The volume of water that passes a given point within a given period of time.

Drainage area The area measured in a horizontal plane and enclosed by a topographic divide from which direct surface runoff from precipitation normally drains by gravity into a stream, upstream from a specified location.

Gage A water-level measuring device at a streamflow-gaging station.

Gage height The water-surface elevation referred to an arbitrary gage datum. Gage height is often used interchangeably with the more general term stage, although gage height is more appropriate when used with a reading on a gage.

Historic peak A peak-flow measurement collected outside the systematic period of record of data collection. Generally a highmagnitude peak of a noteworthy flood.

Hydrologic unit A geographic area representing part or all of a surface-water drainage basin or distinct hydrologic feature as delineated on a State Hydrologic Unit Map prepared by the U.S. Geological Survey.

Location A description of the placement of a streamflow-gaging station. Location may include the latitude, longitude, datum, county, and hydrologic unit code of the station.

Regulation The artificial manipulation of the flow of a stream.

Remarks Additional information enriching the characterization of a streamflow-gaging station.

Stage-discharge relation The relation between gage height and the rate at which water flows in a stream. It is defined by measurements of stage and discharge, by theoretical assumptions based on hydraulic properties of the stream channel or manmade flow-confining structures, or by a combination of both.

Streamgaging or streamflow-gaging station A particular site on a stream, canal, lake, or reservoir where systematic observations of water heights and water discharges are made.

Water year The 12-month period from October 1 through September 30. The date of the water year is designated by the calendar year in which the period ends and which includes 9 of the 12 months. A water year beginning October 1, 2005, and ending September 30, 2006, is called the "2006 water year." 


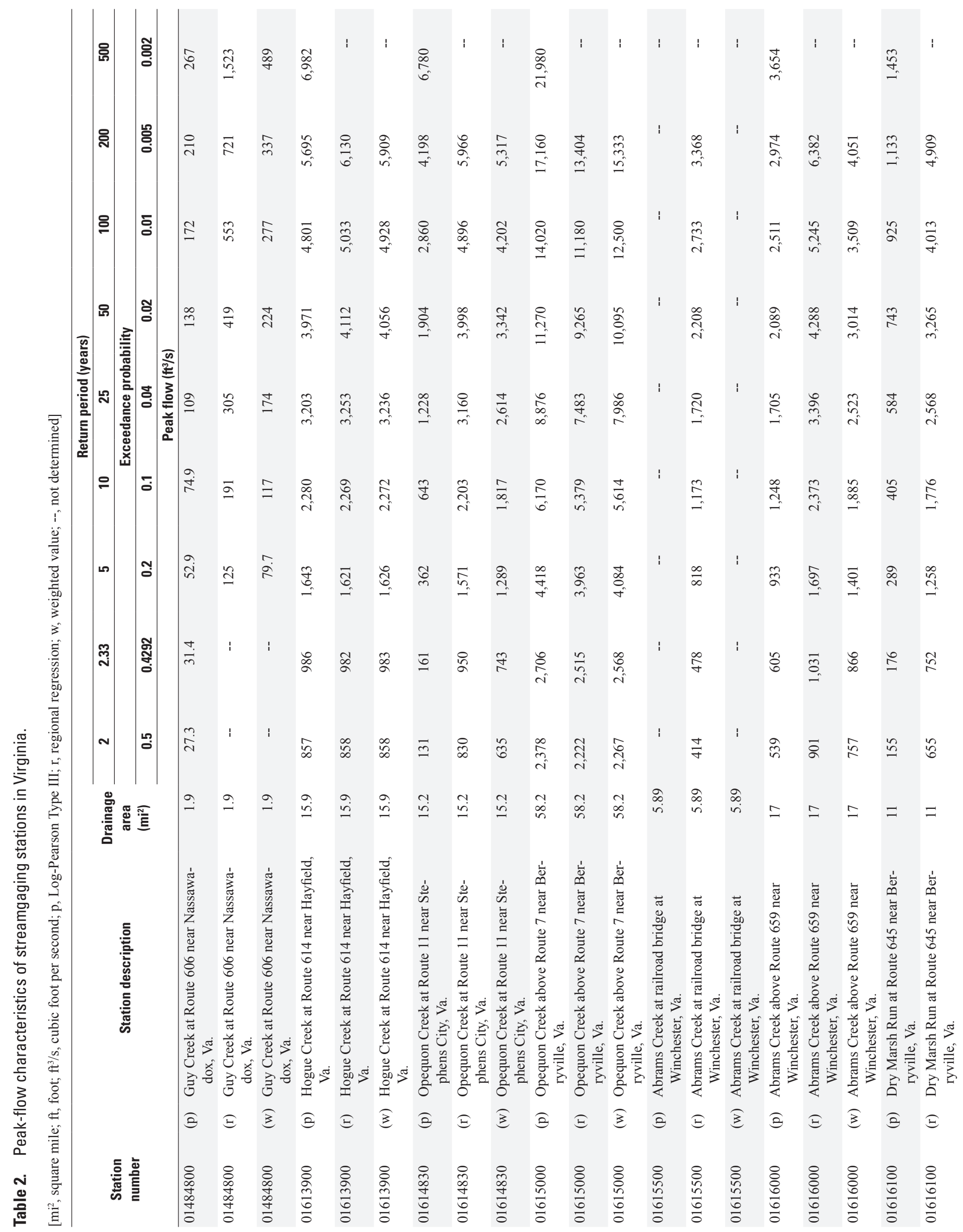




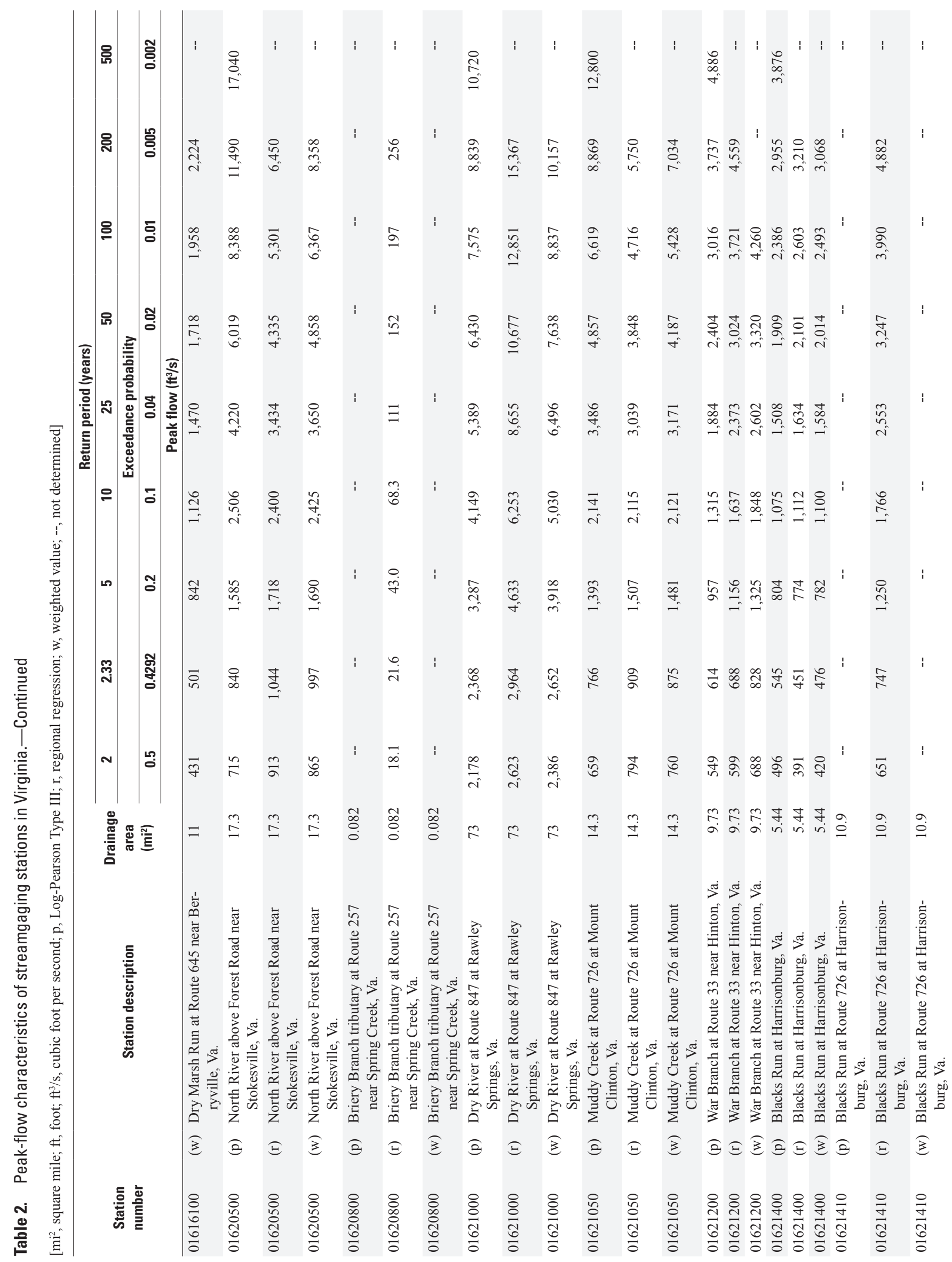




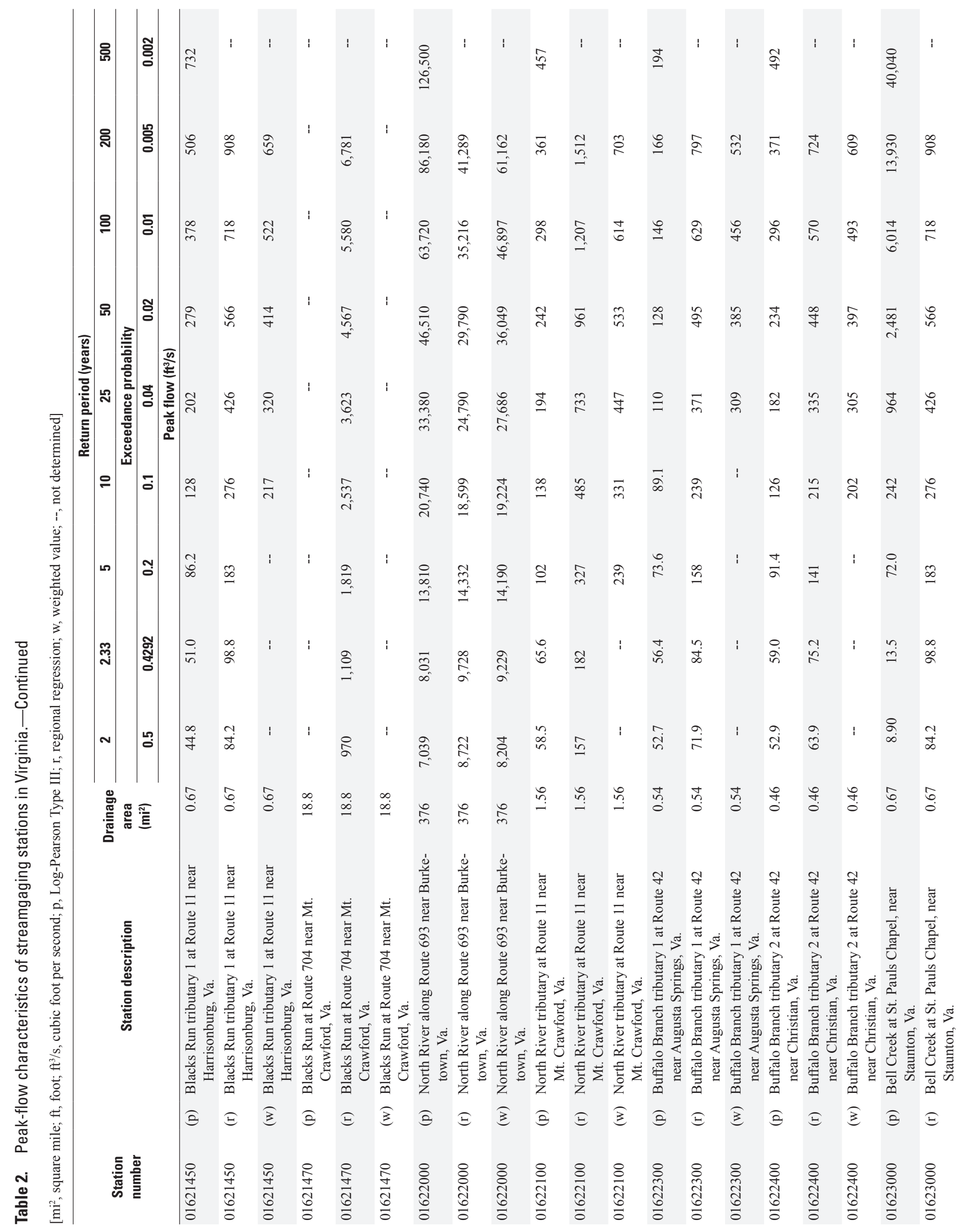




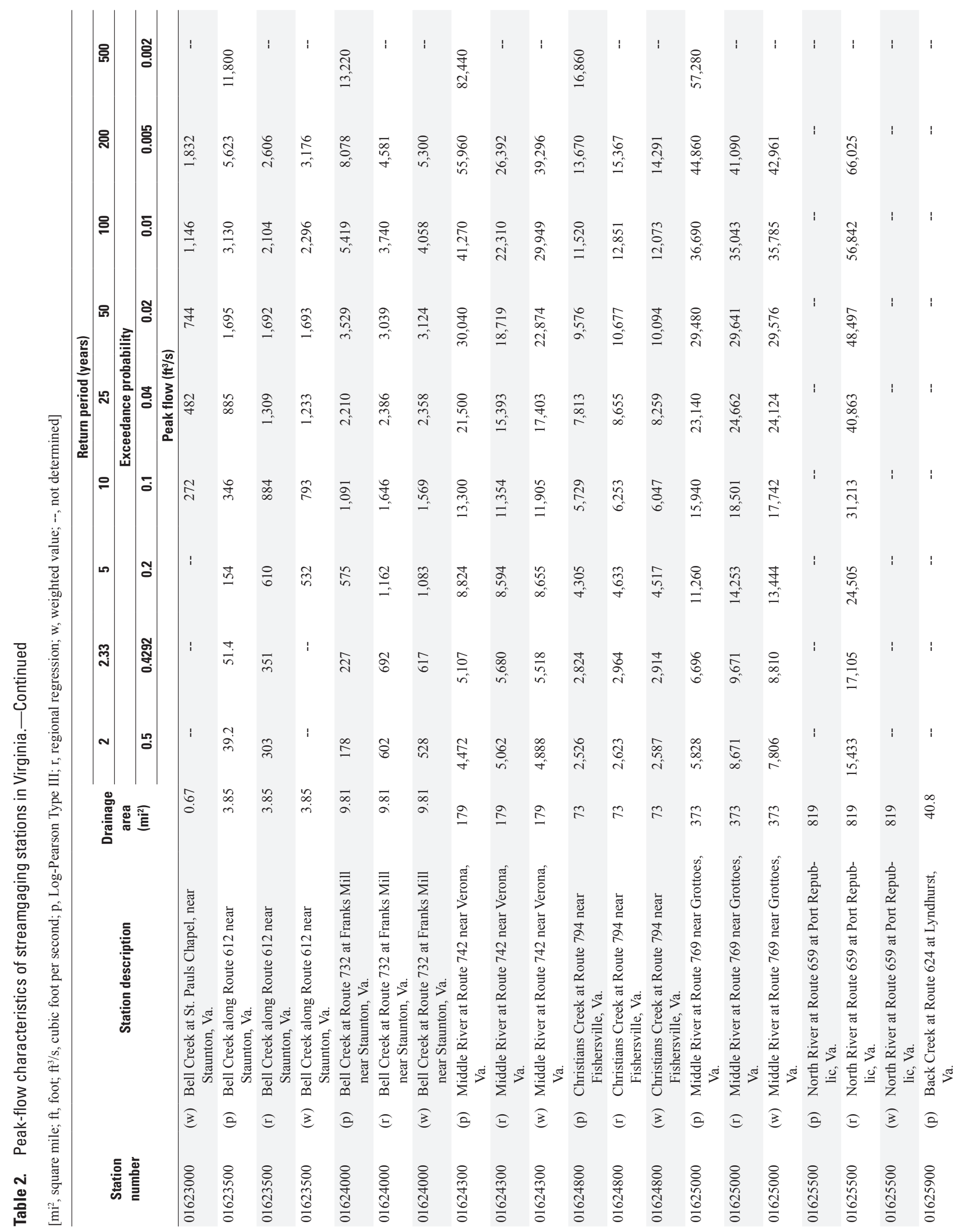




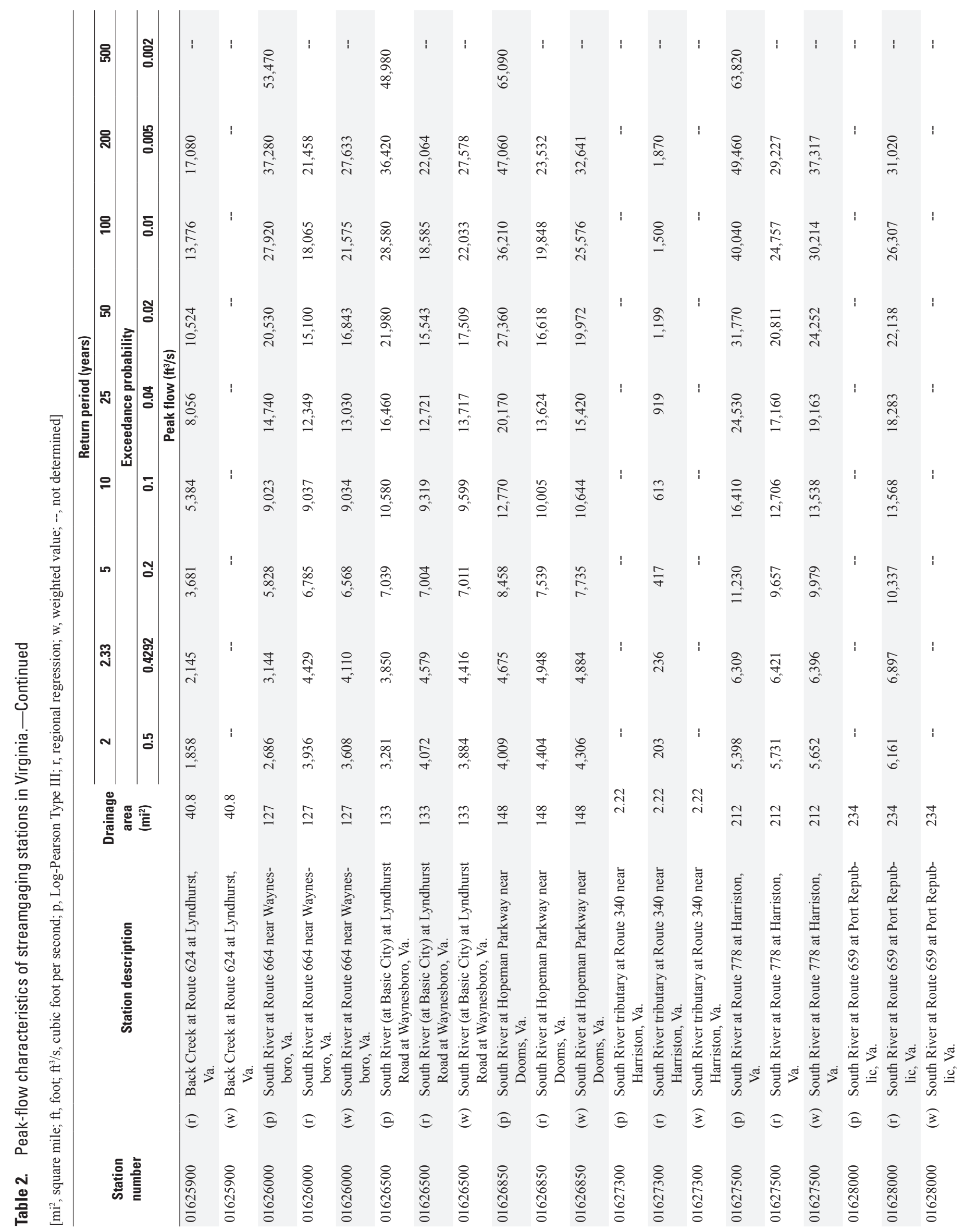




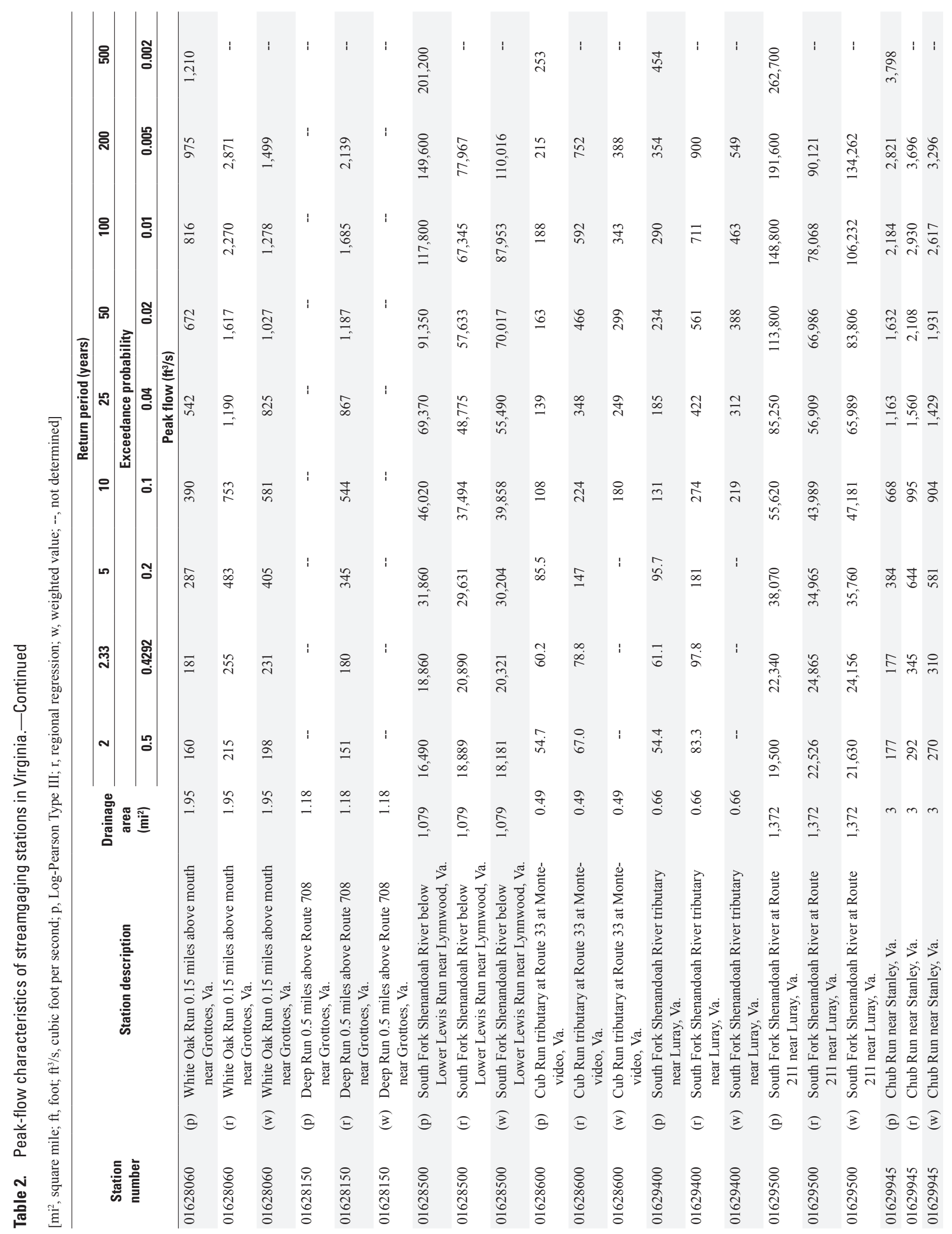




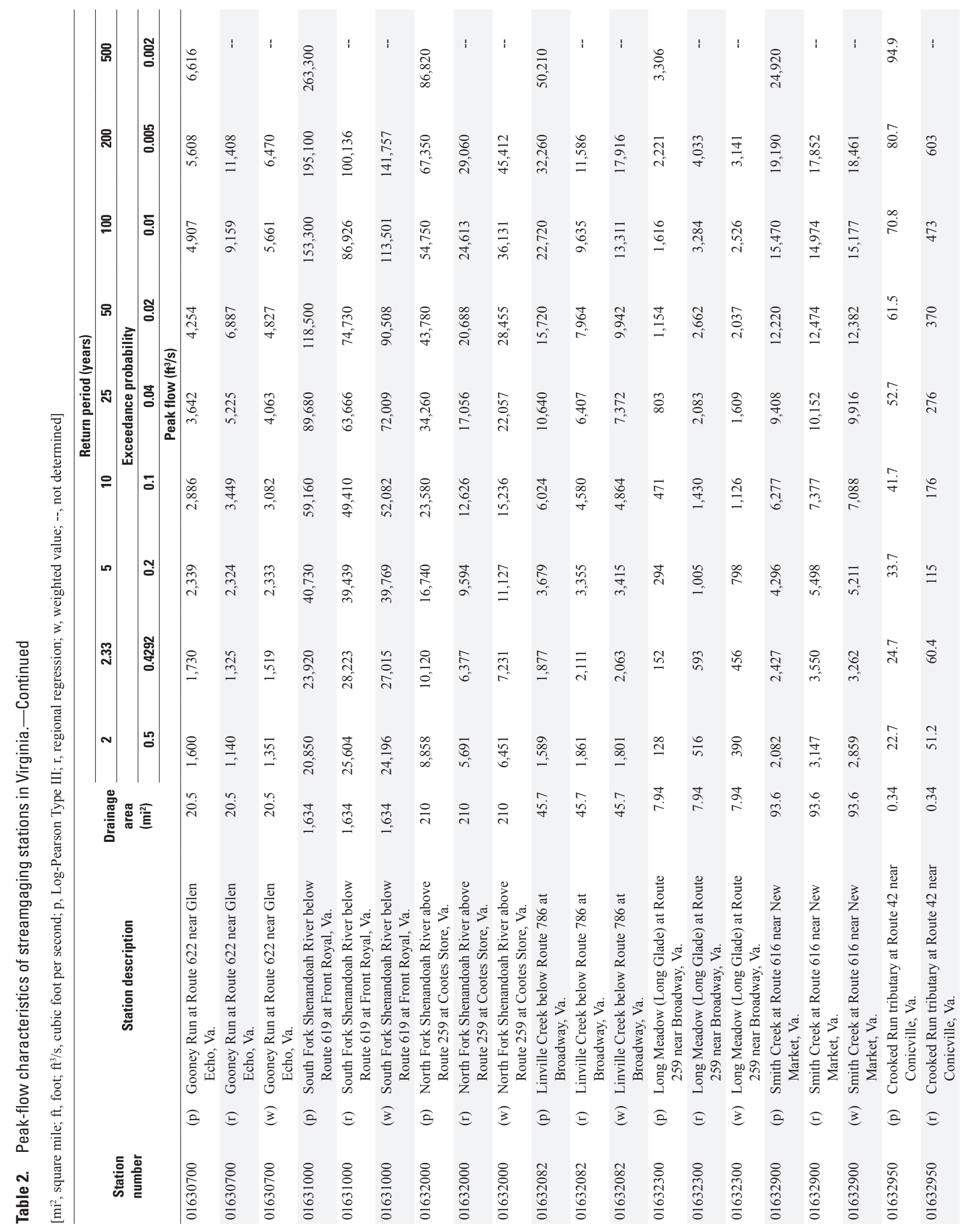




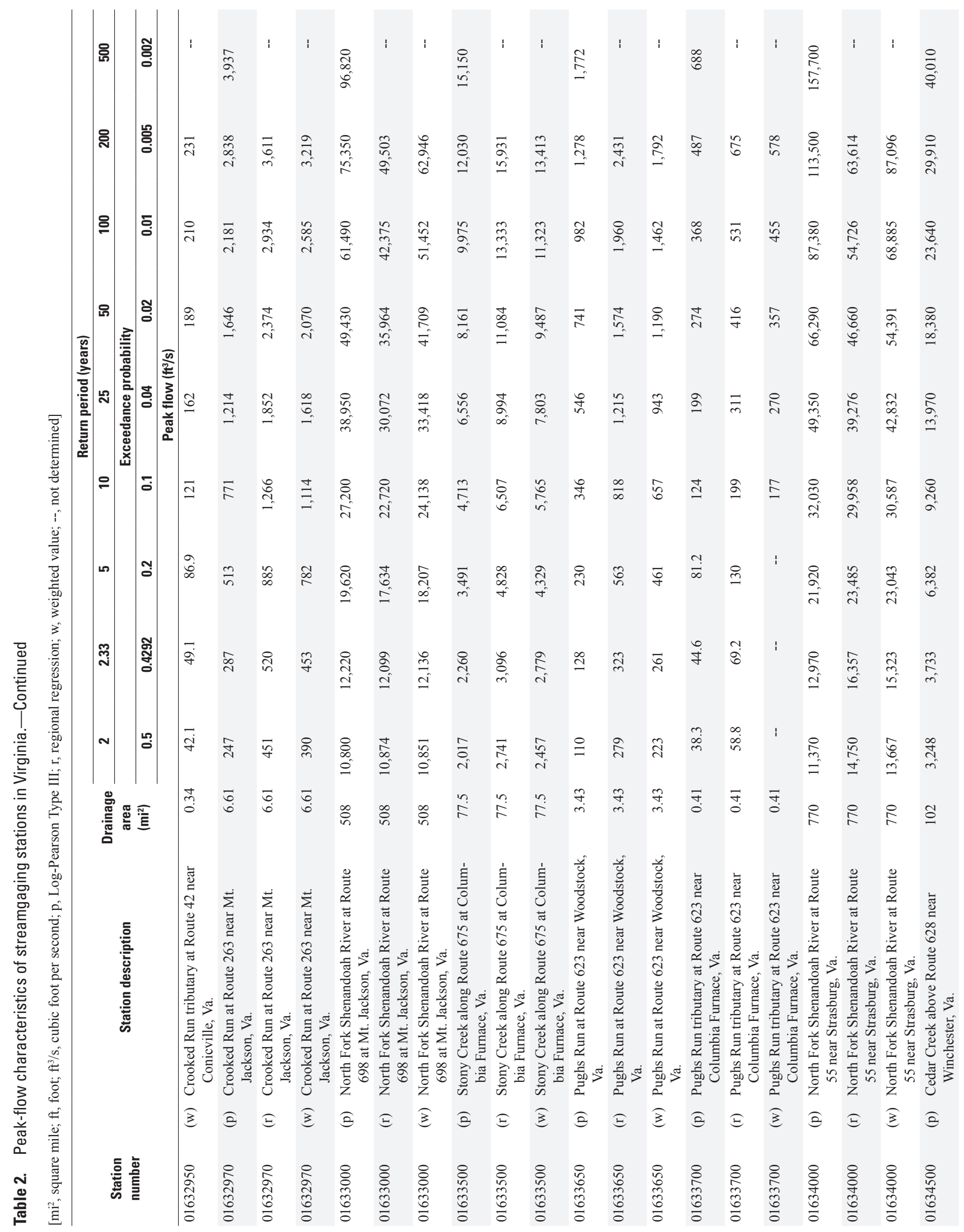




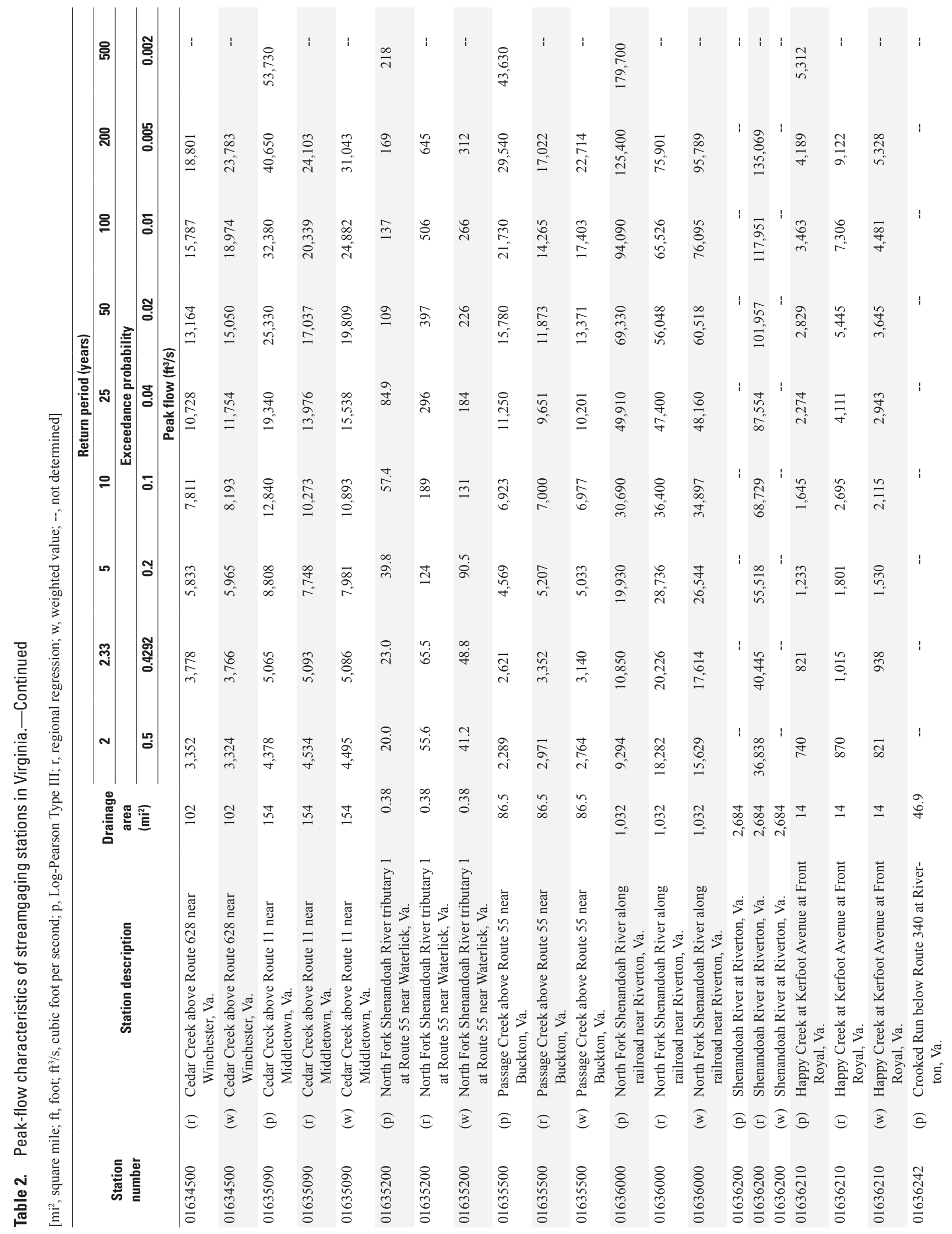




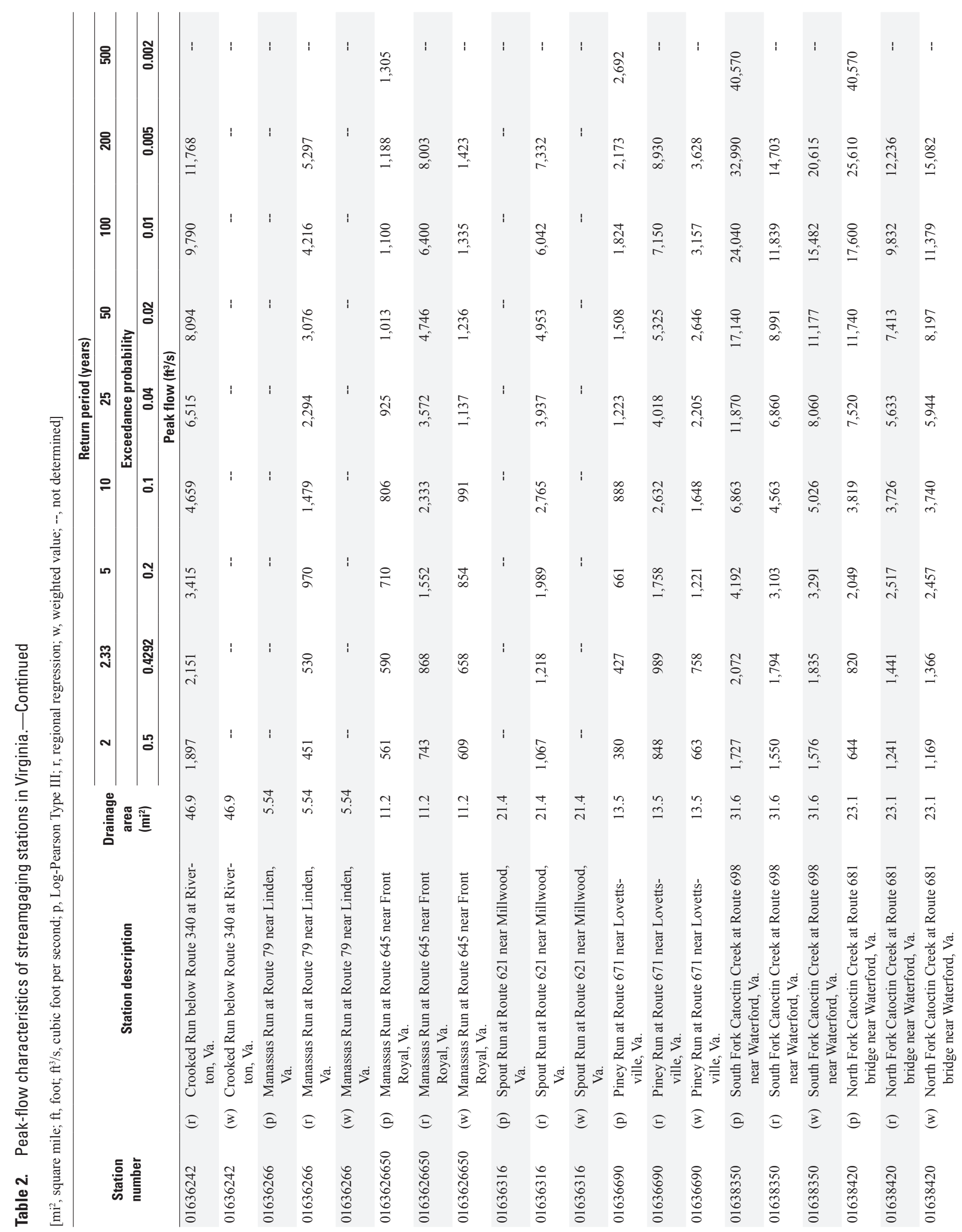




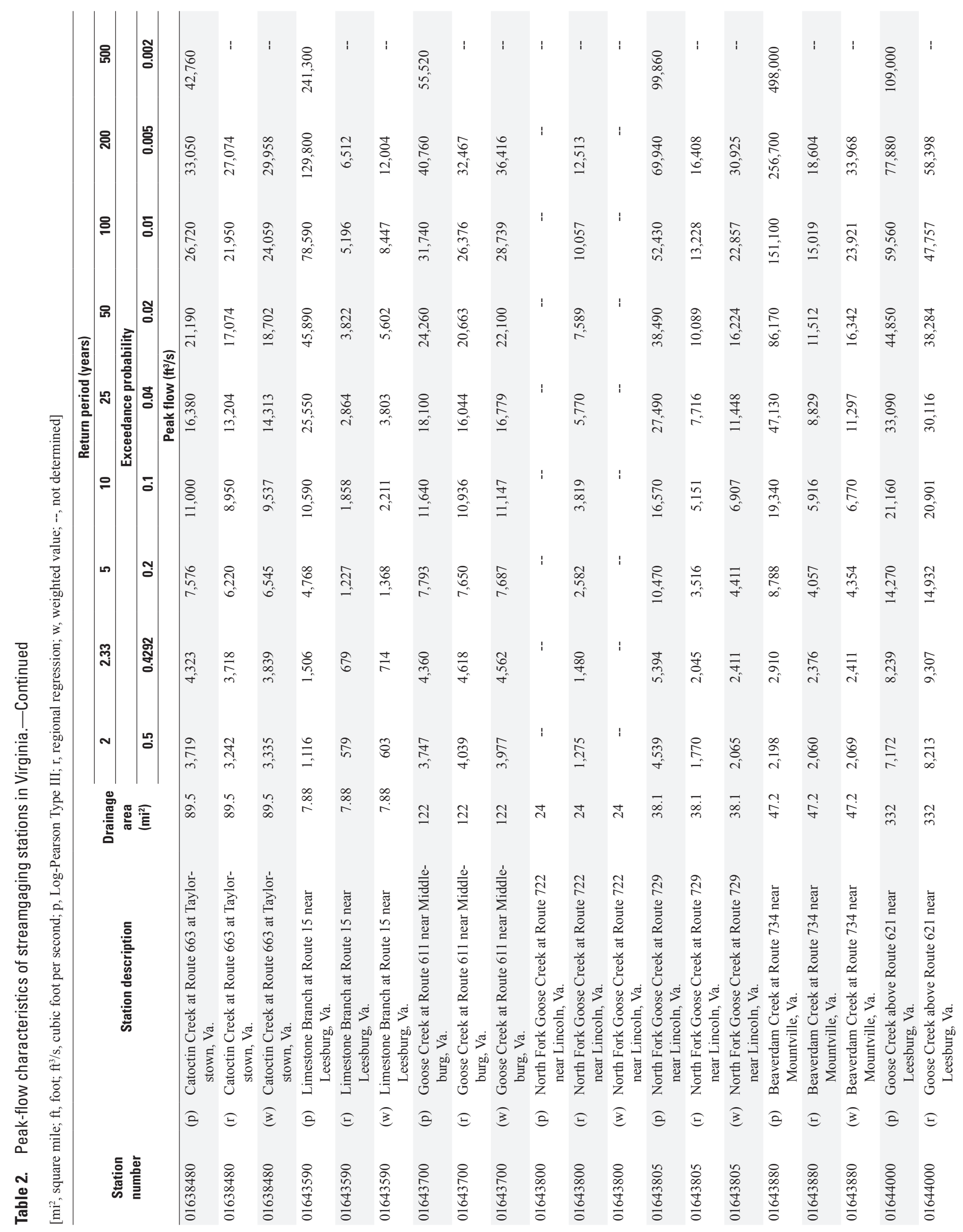




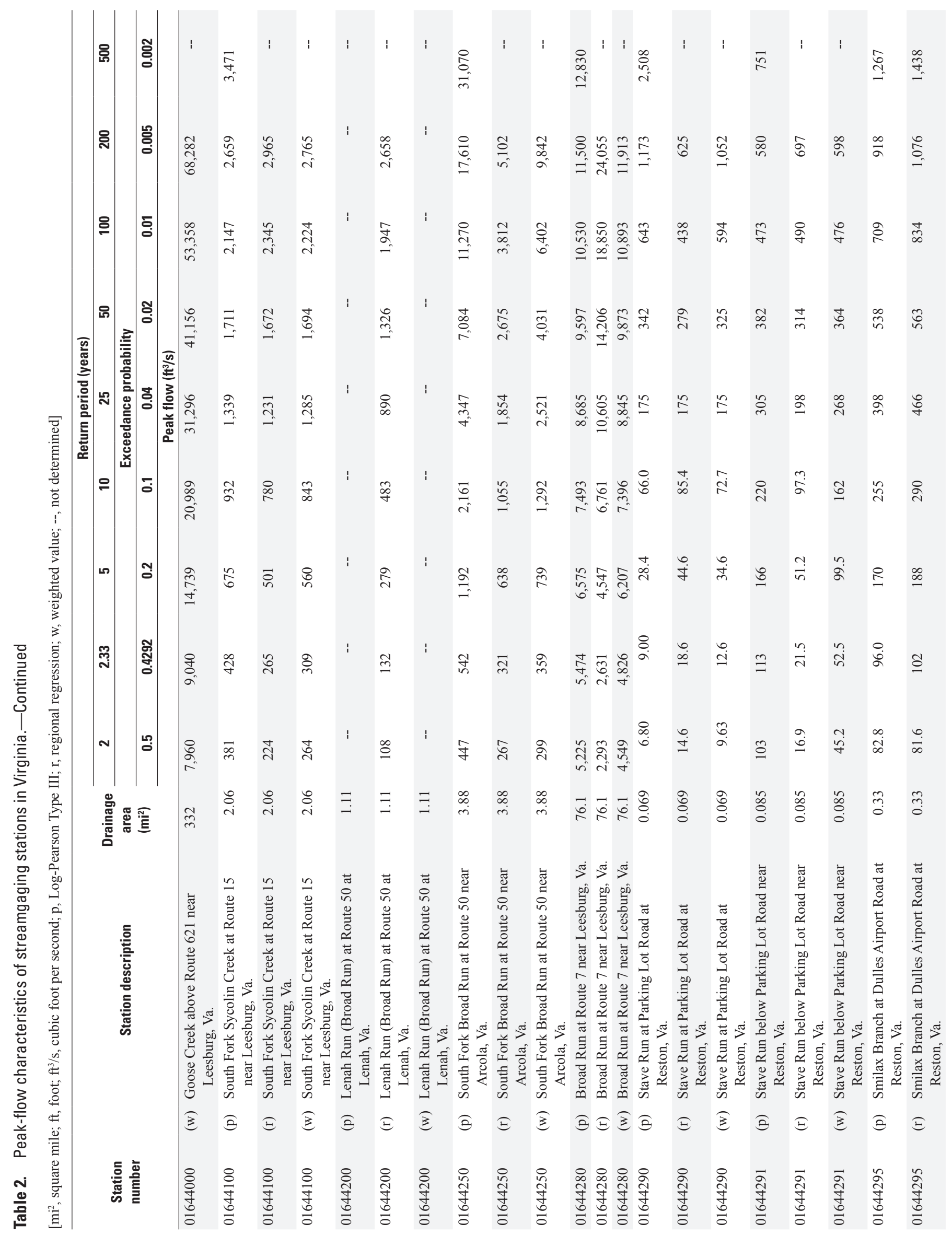




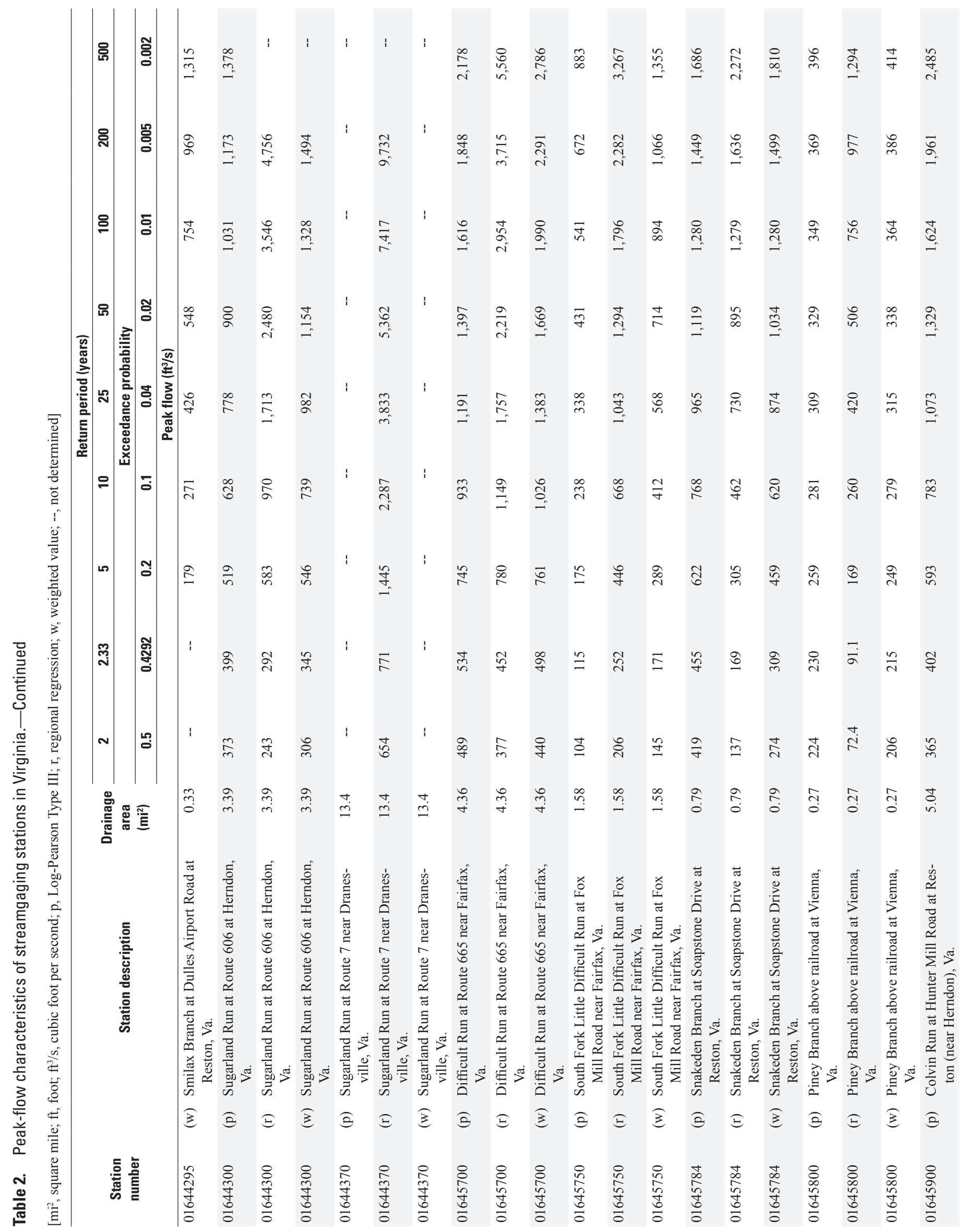




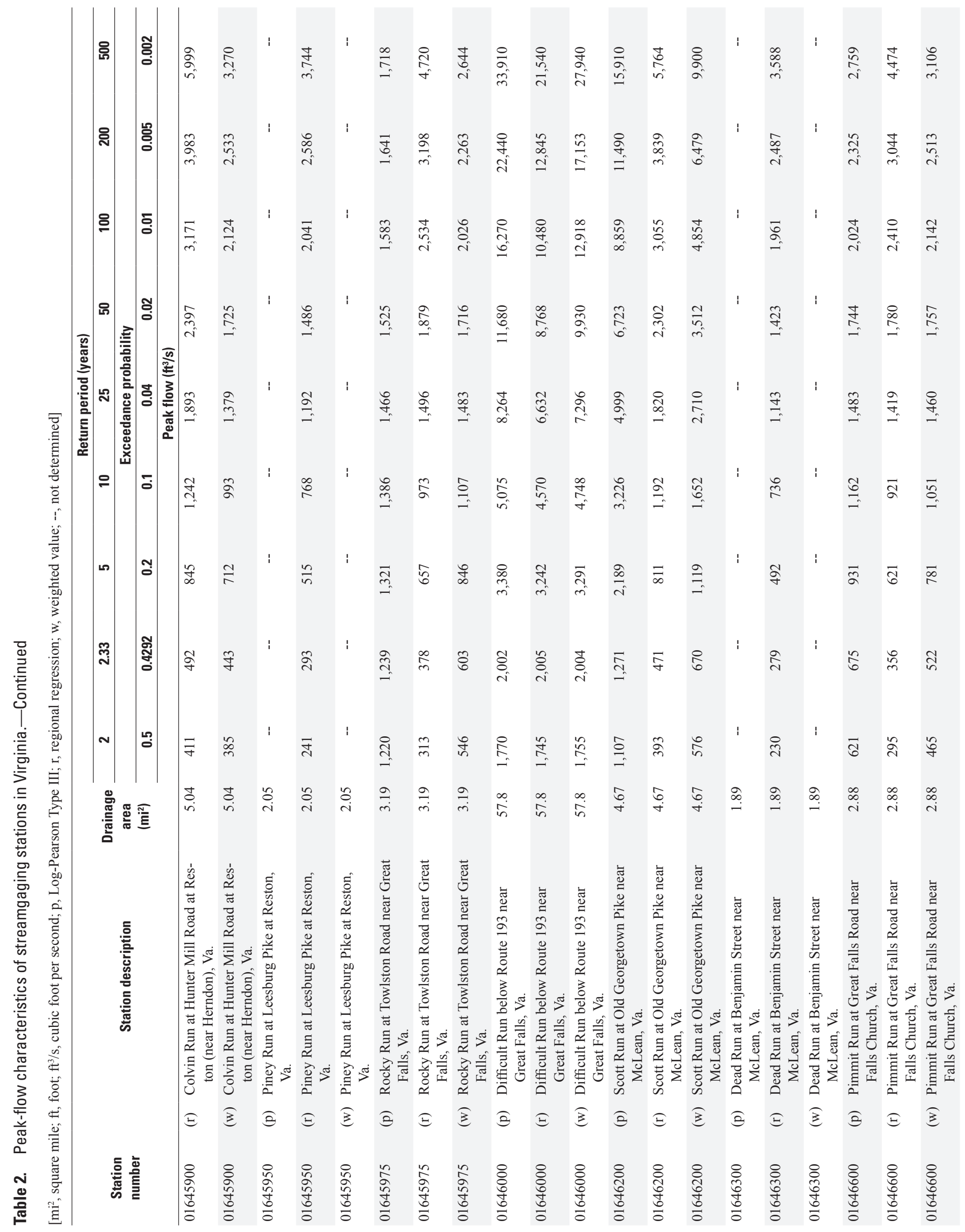




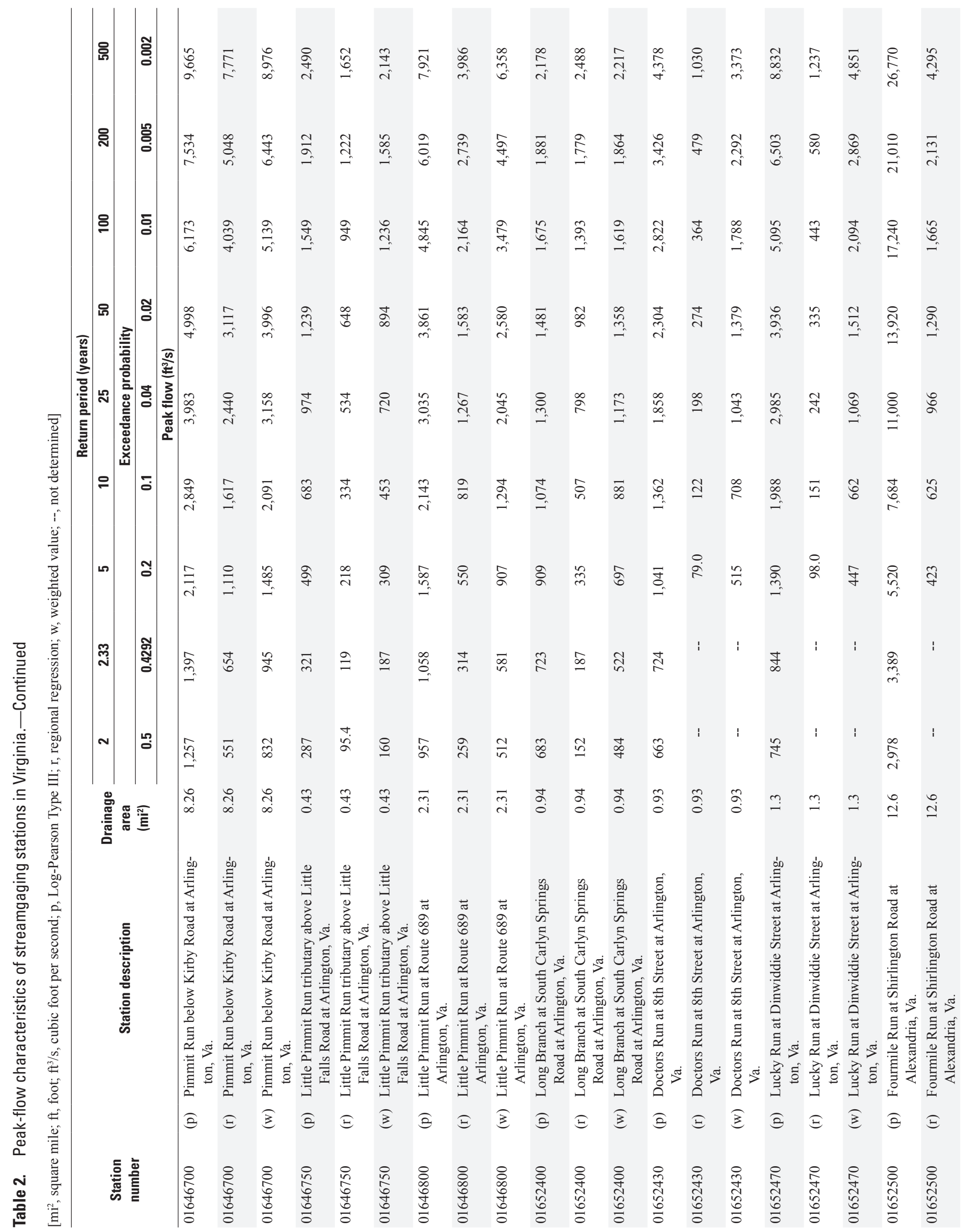




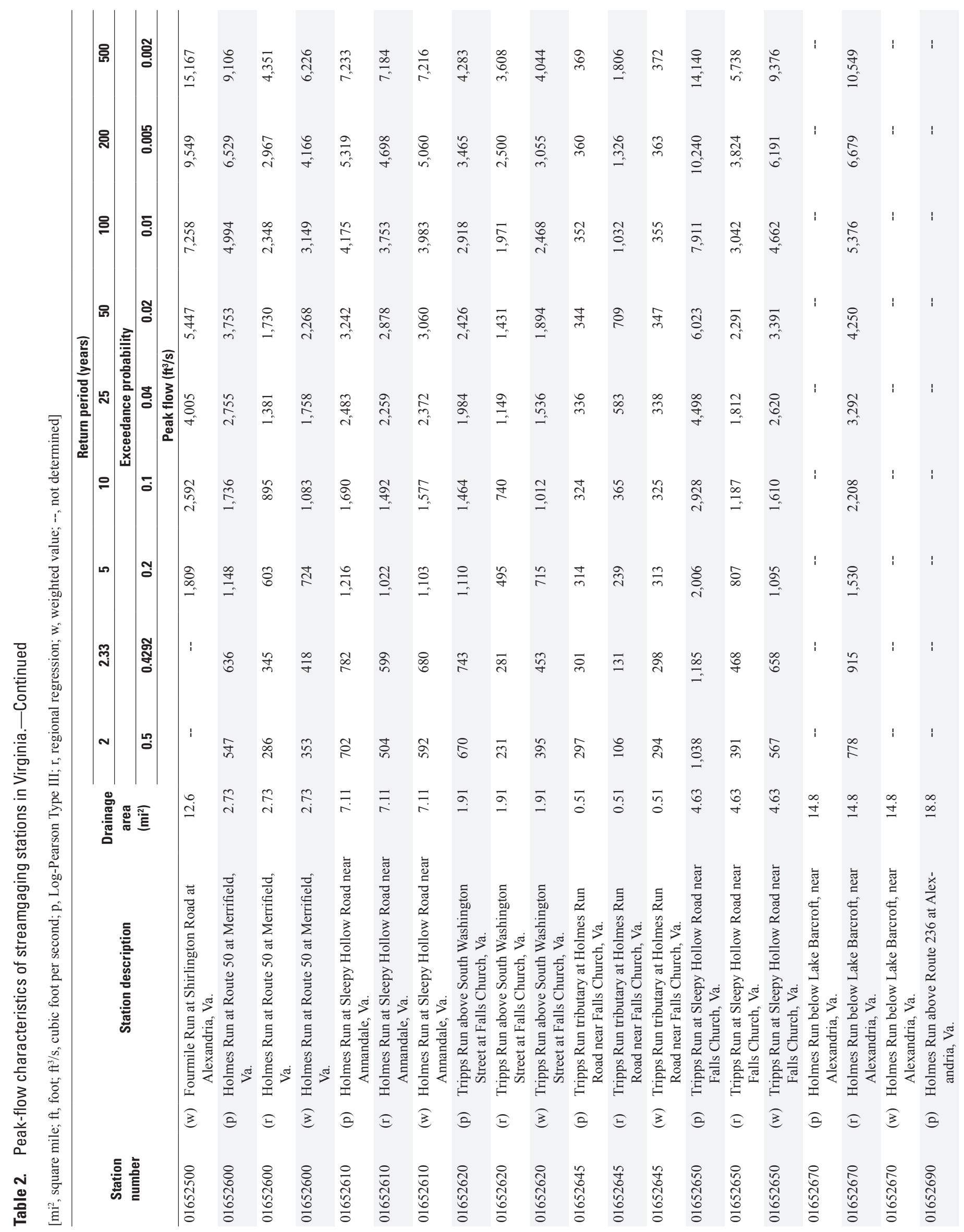




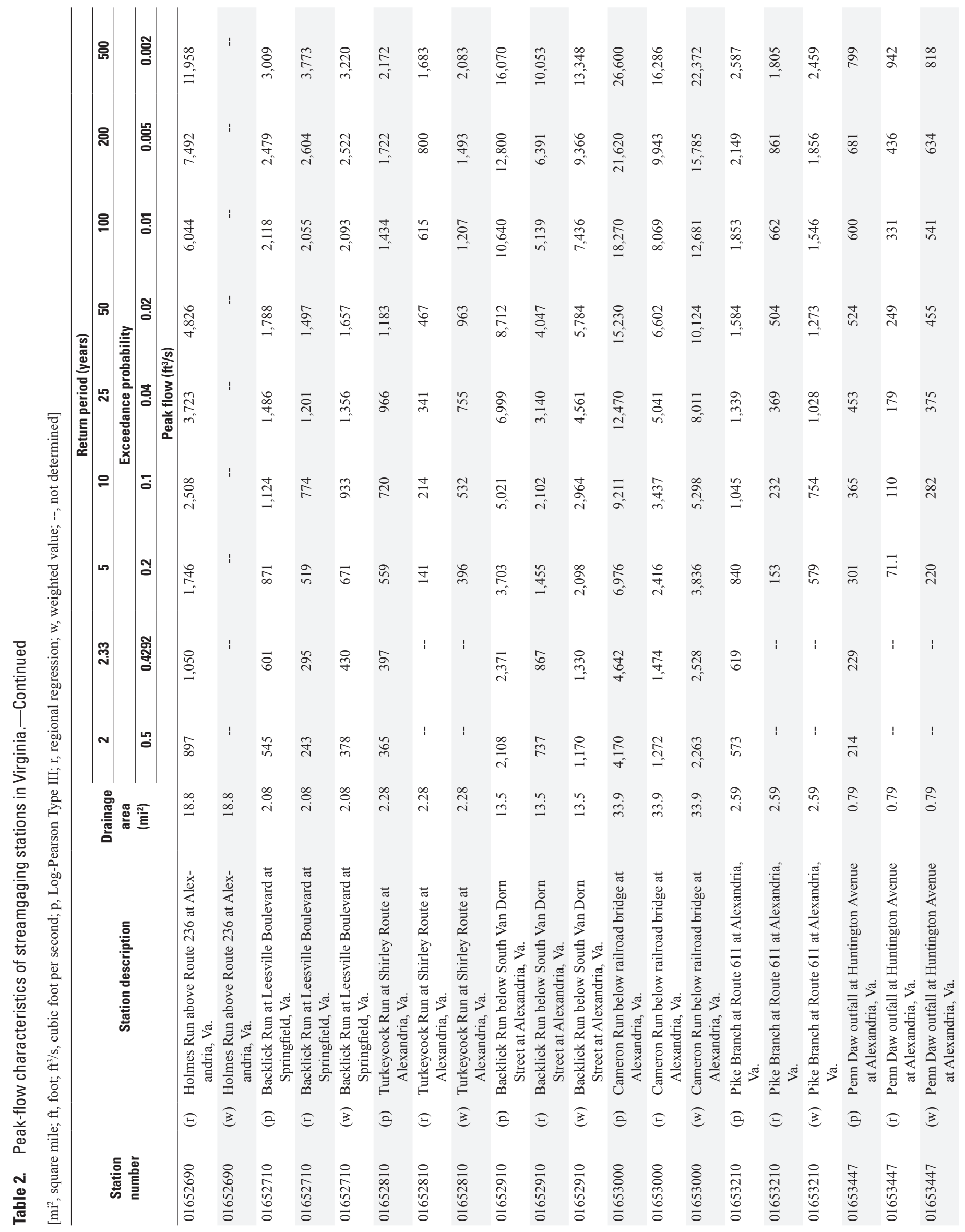




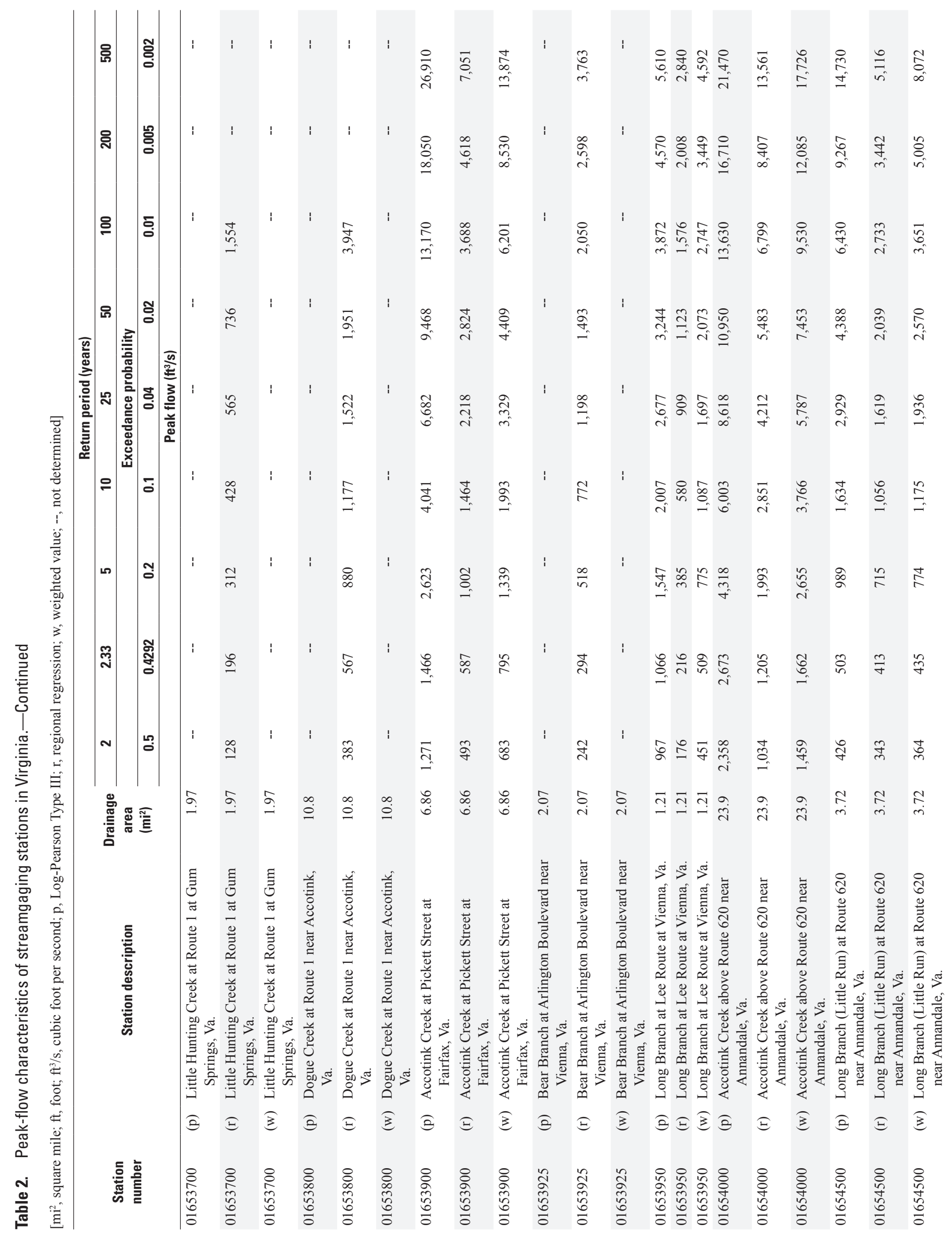




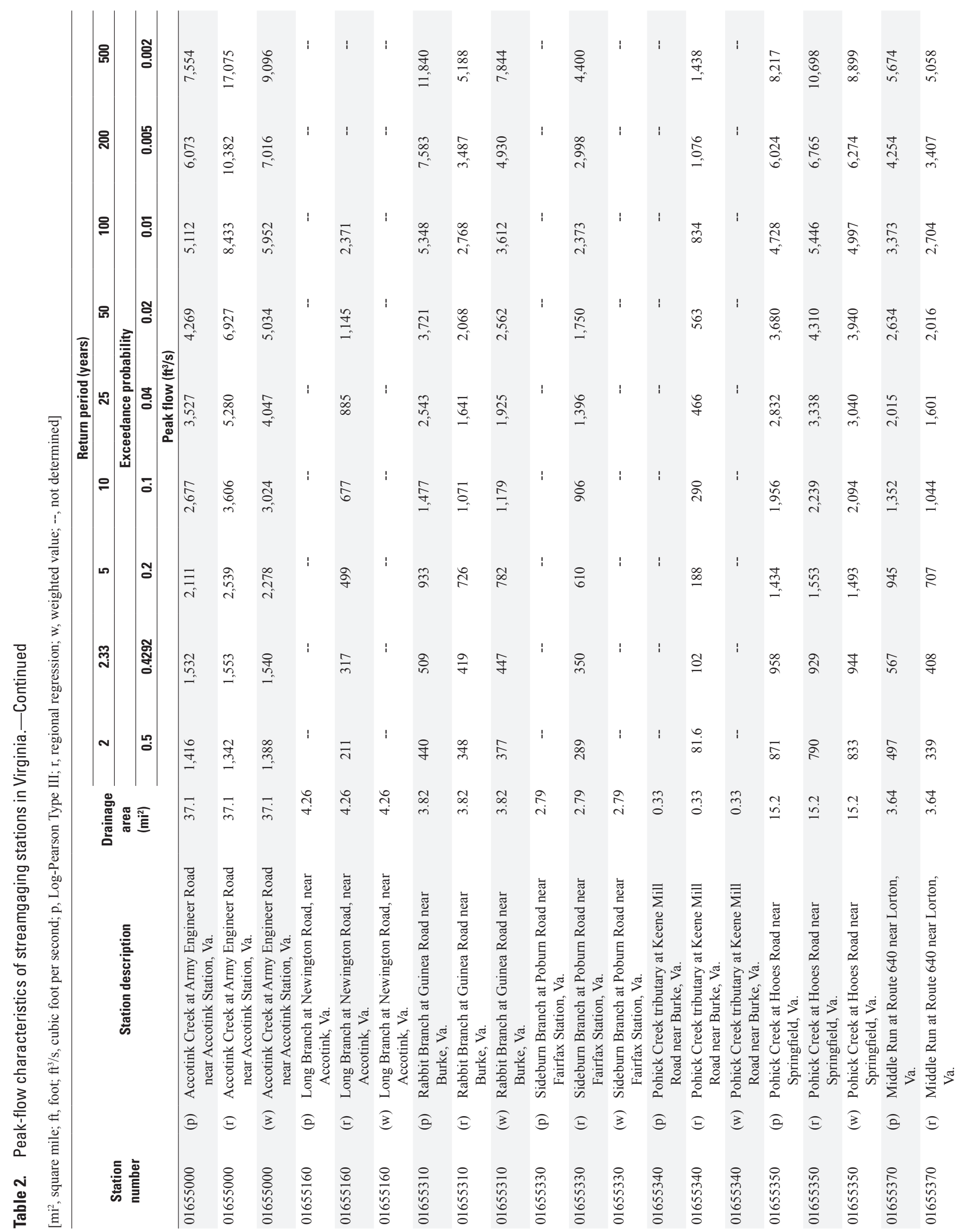




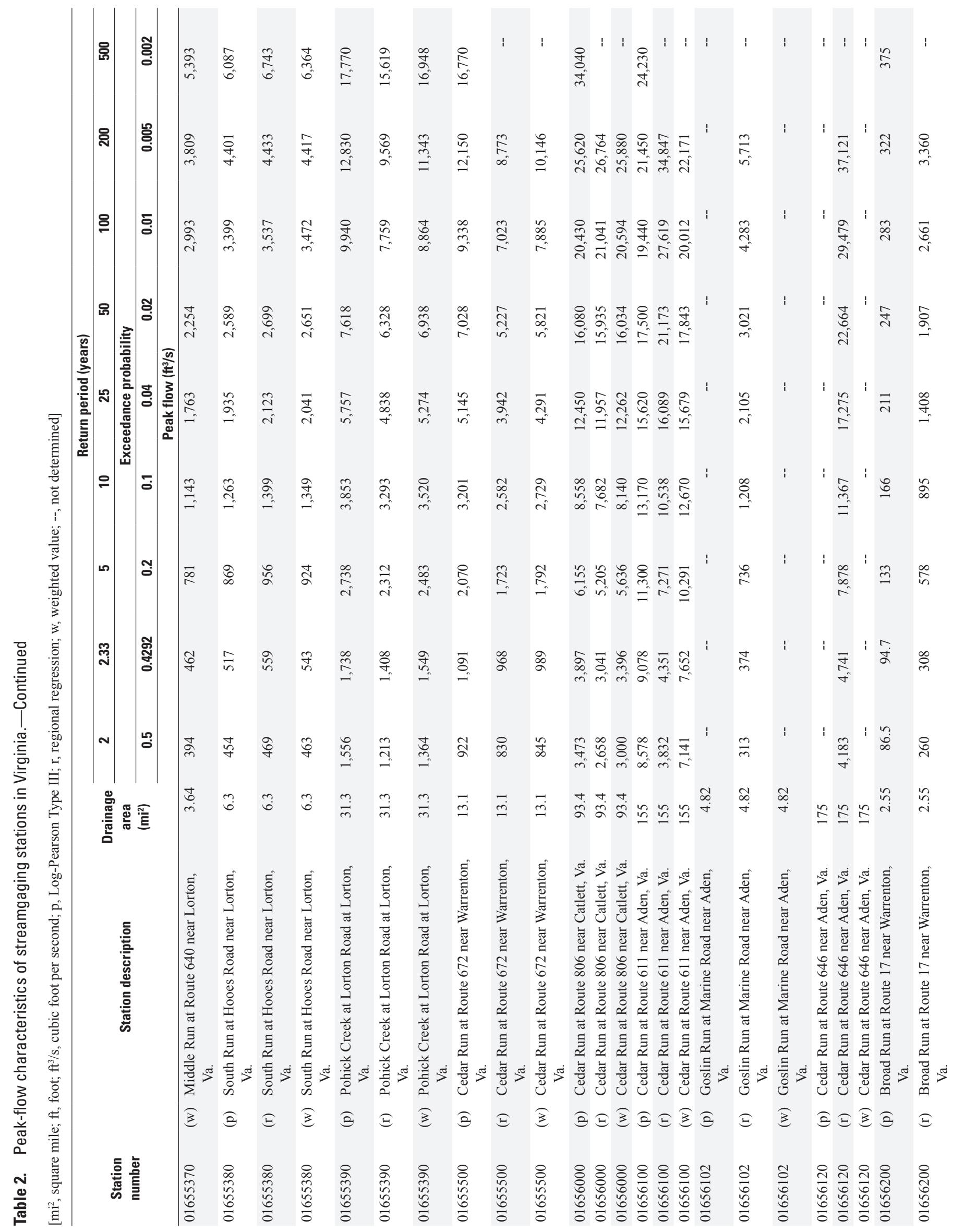




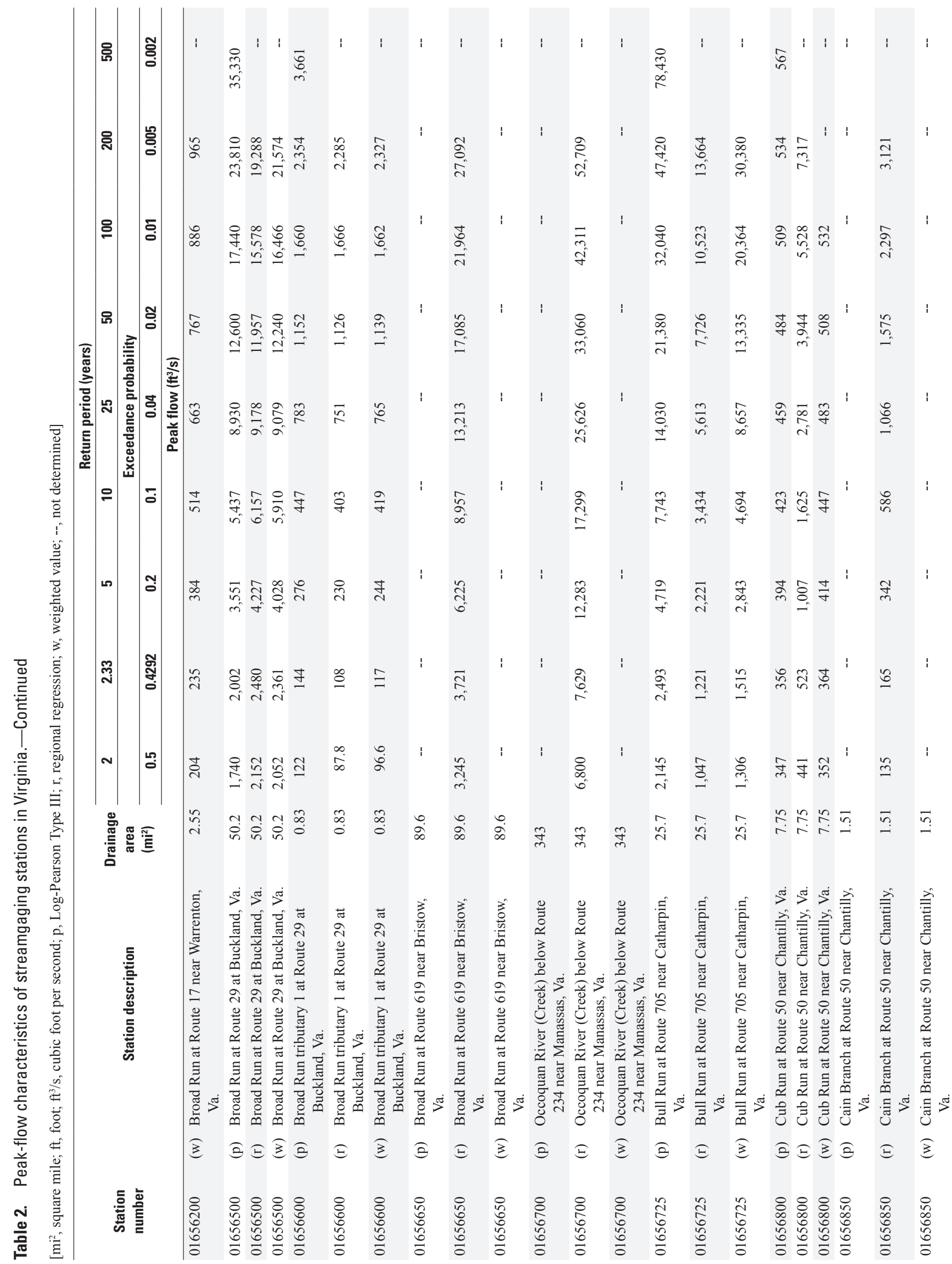




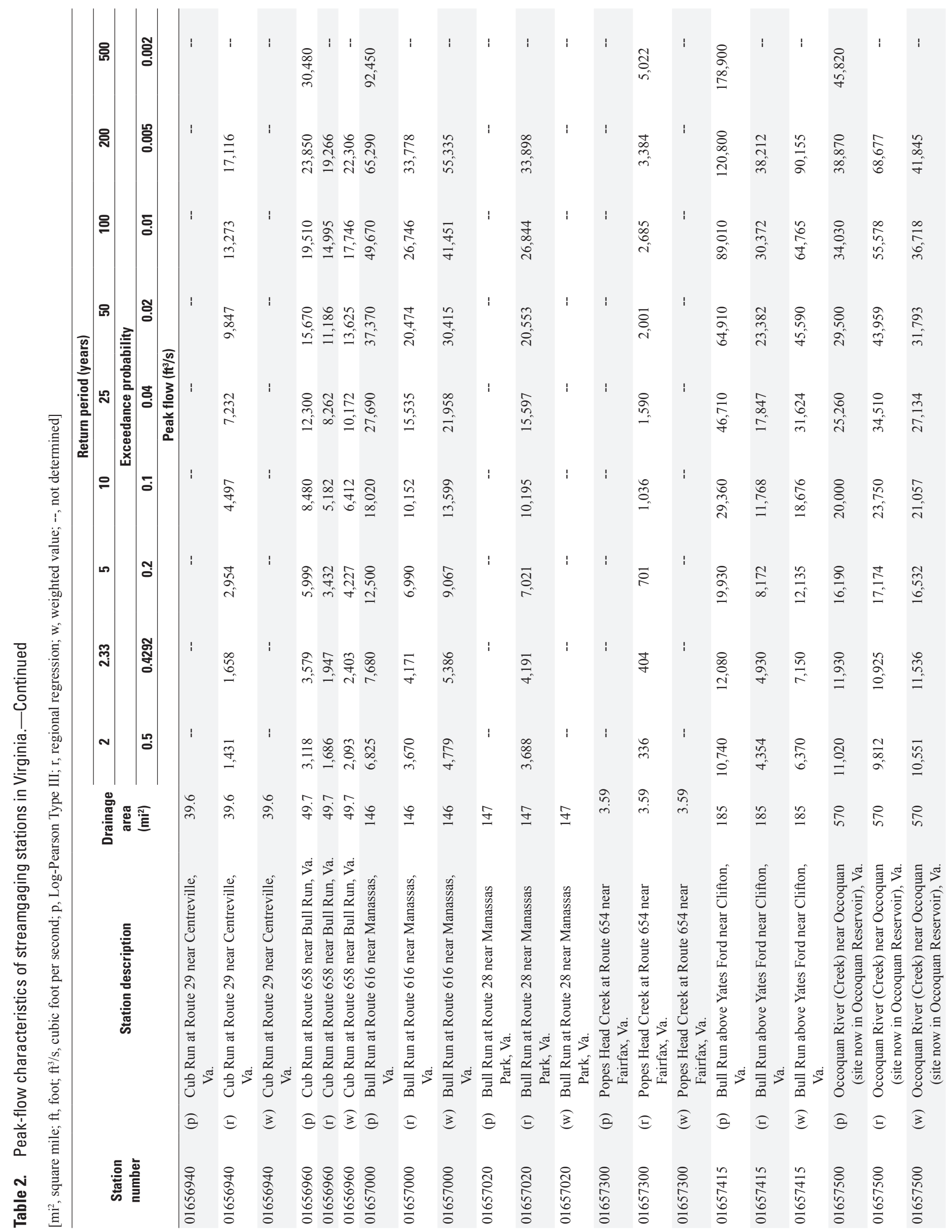




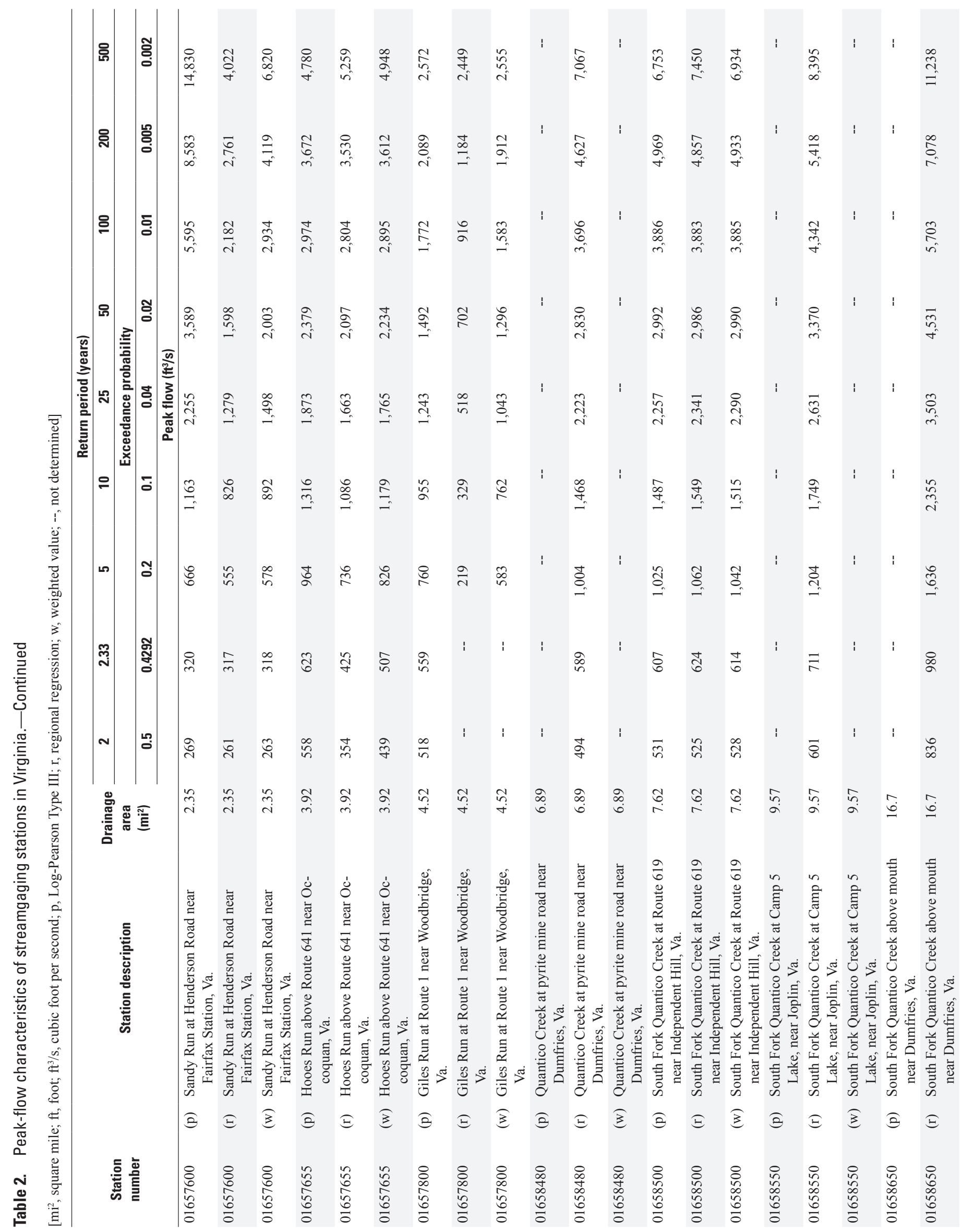




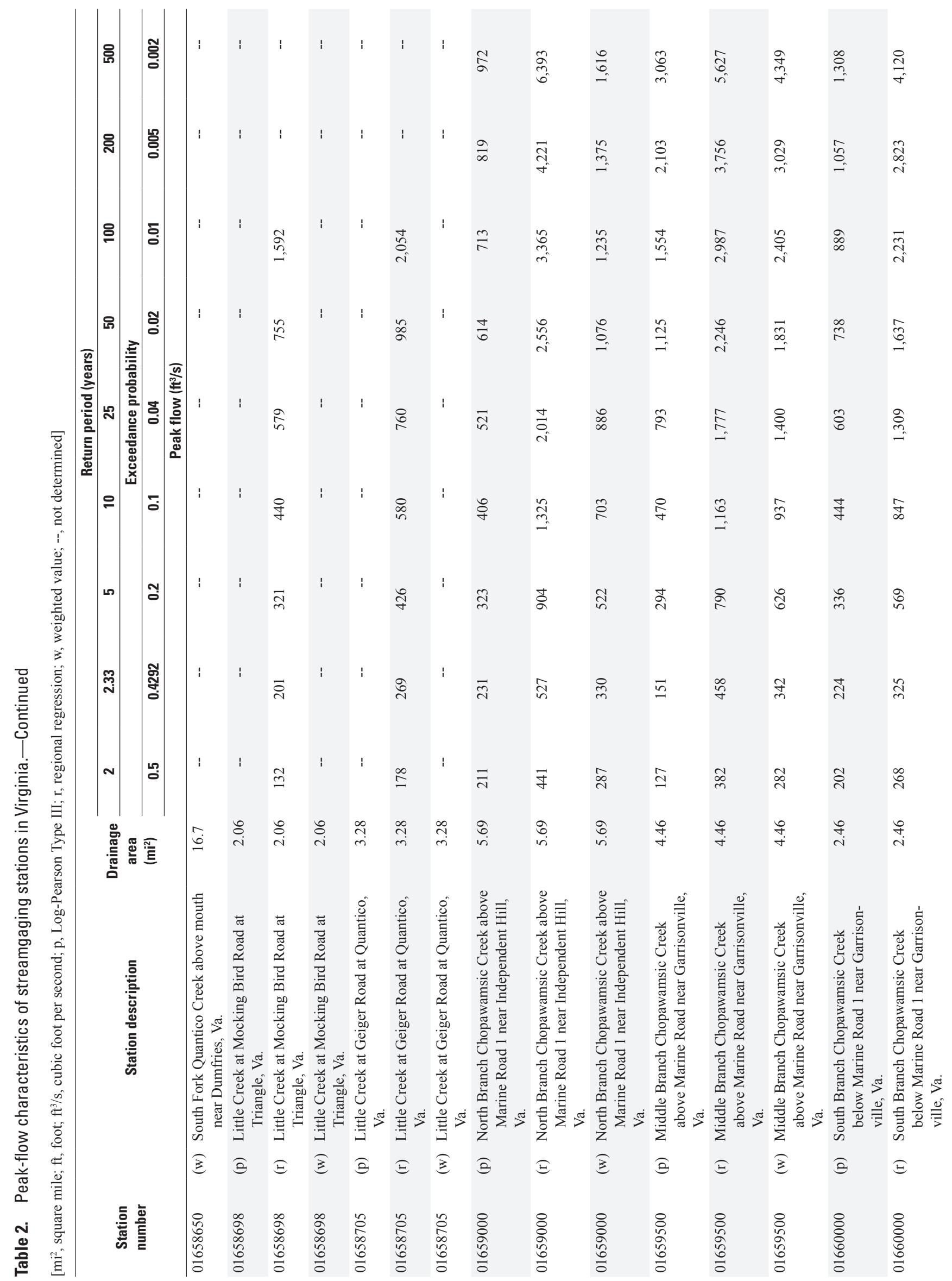




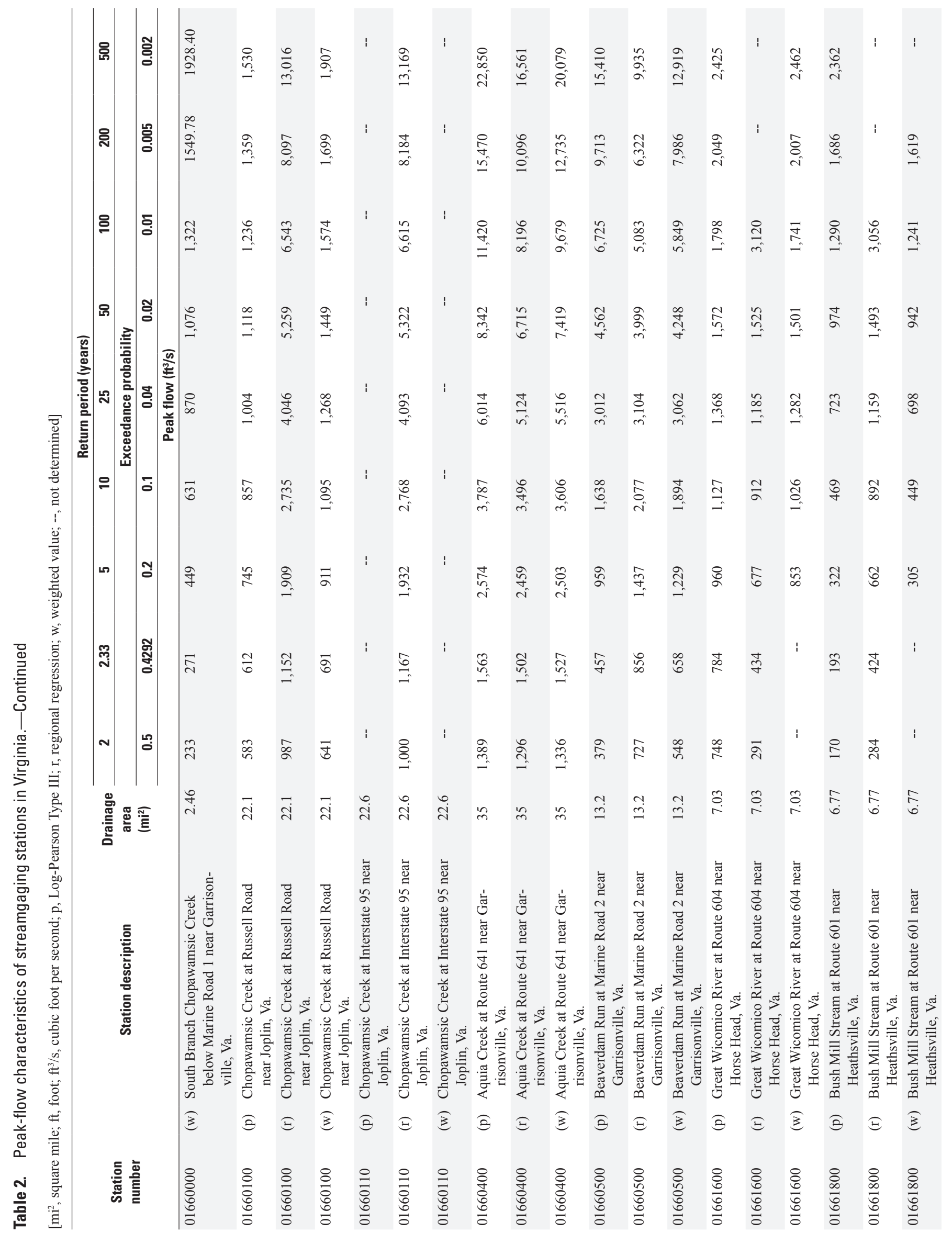




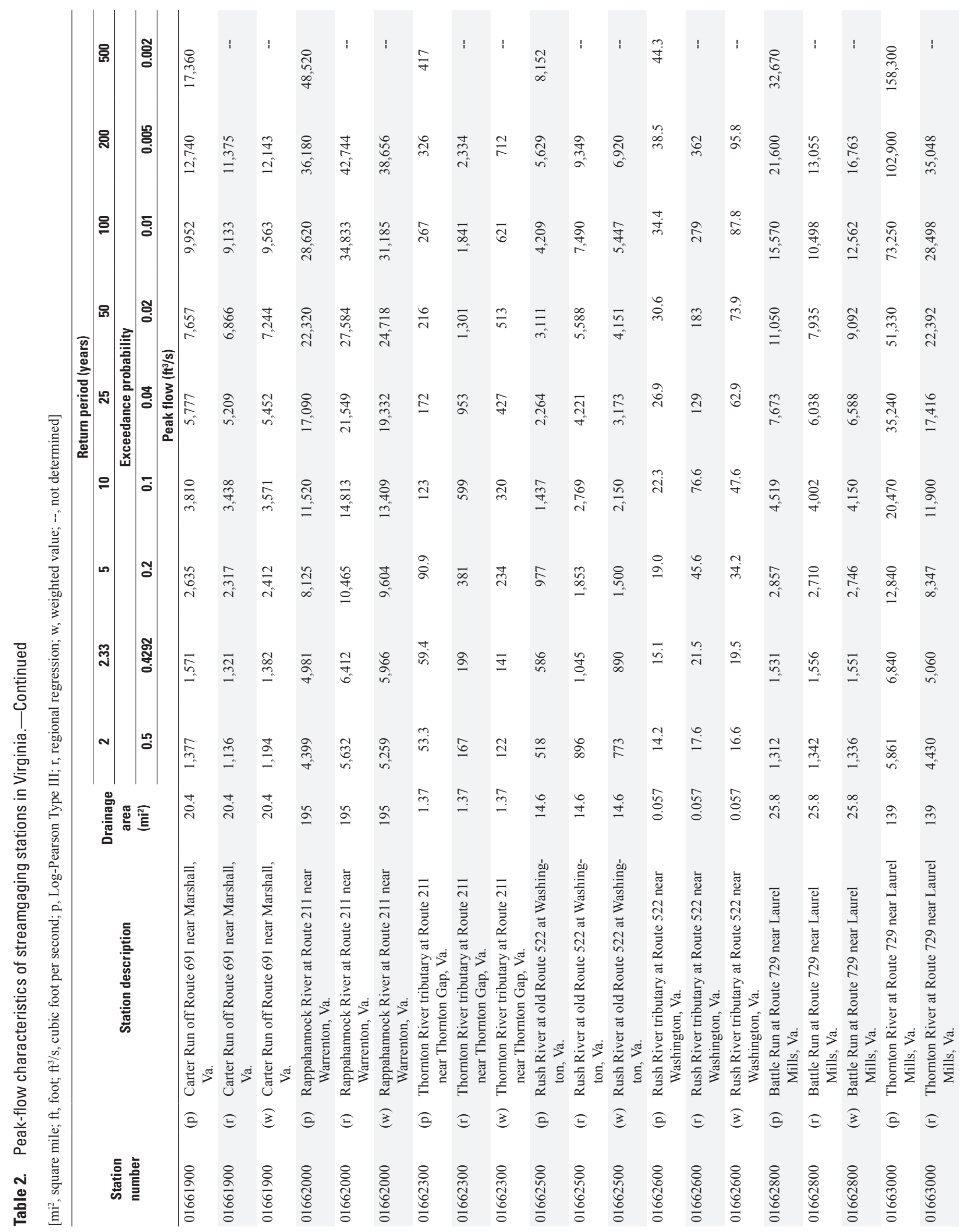




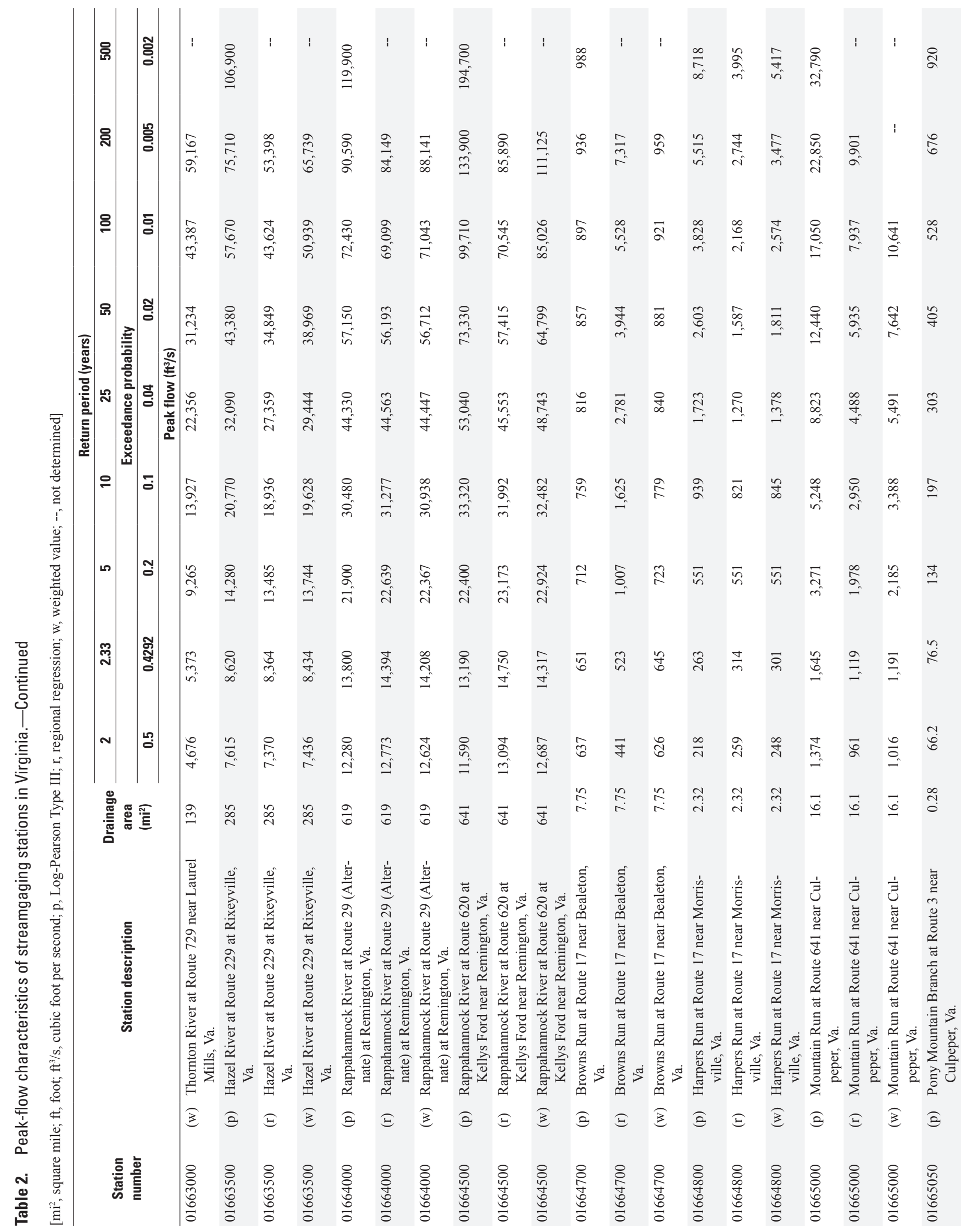




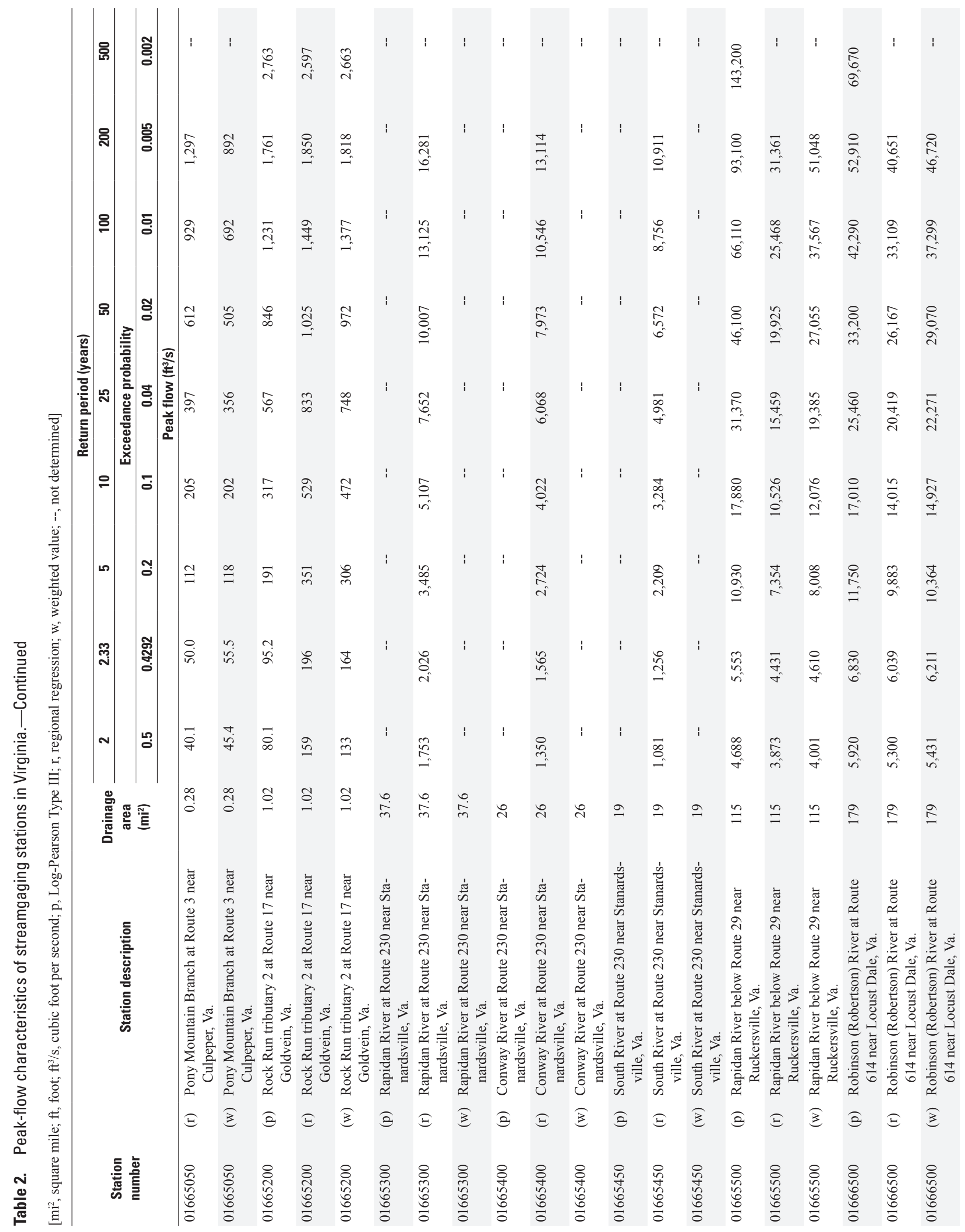




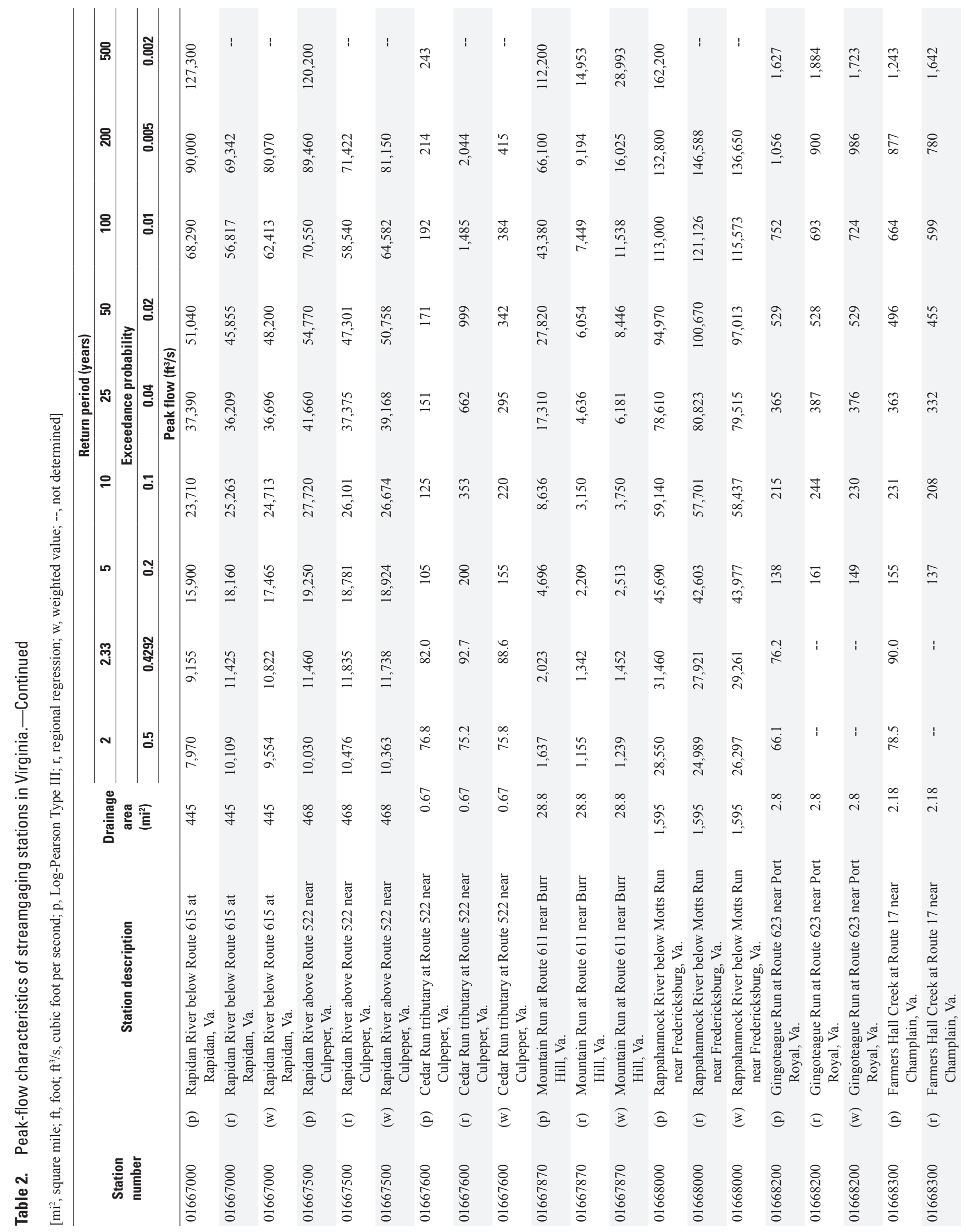




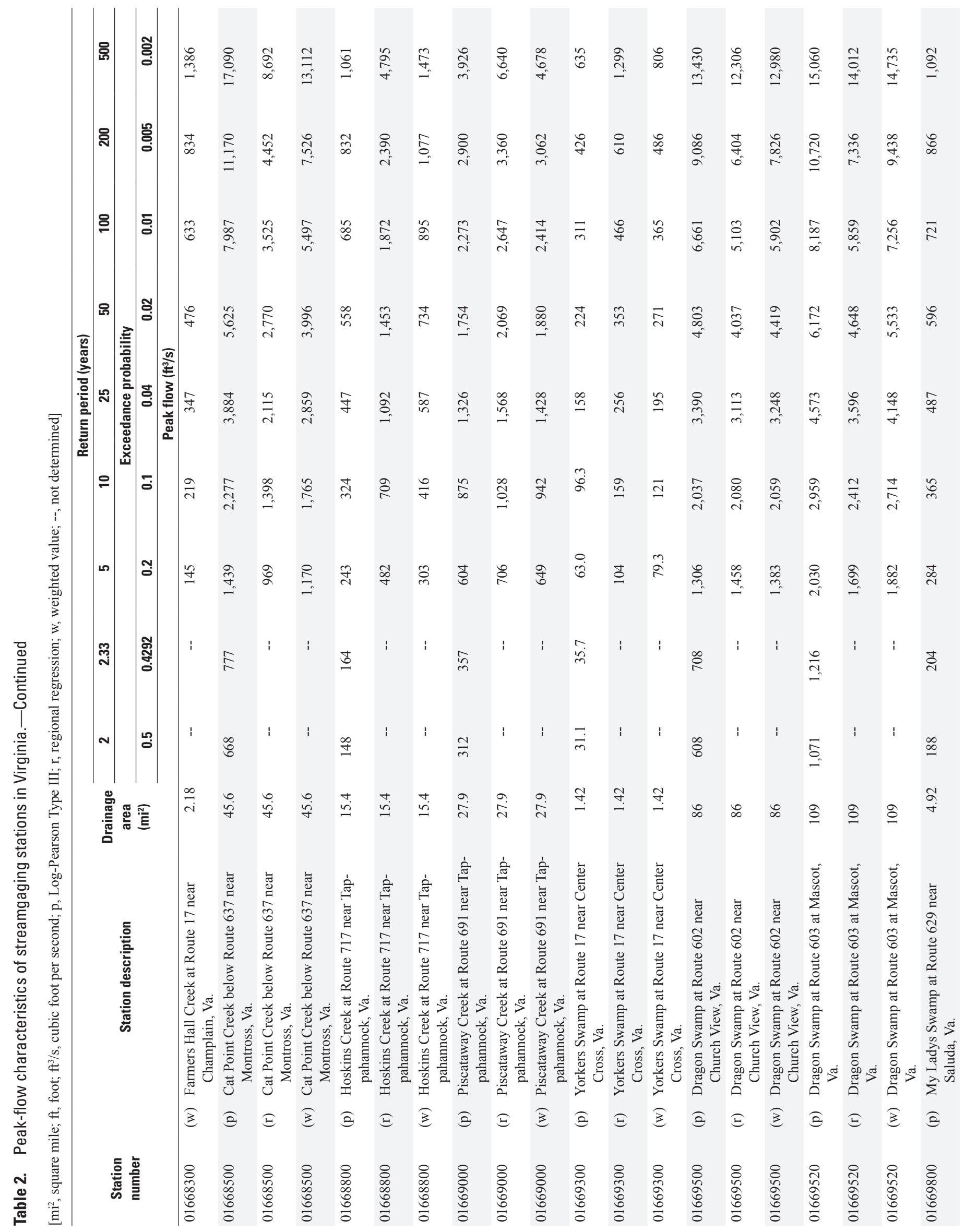




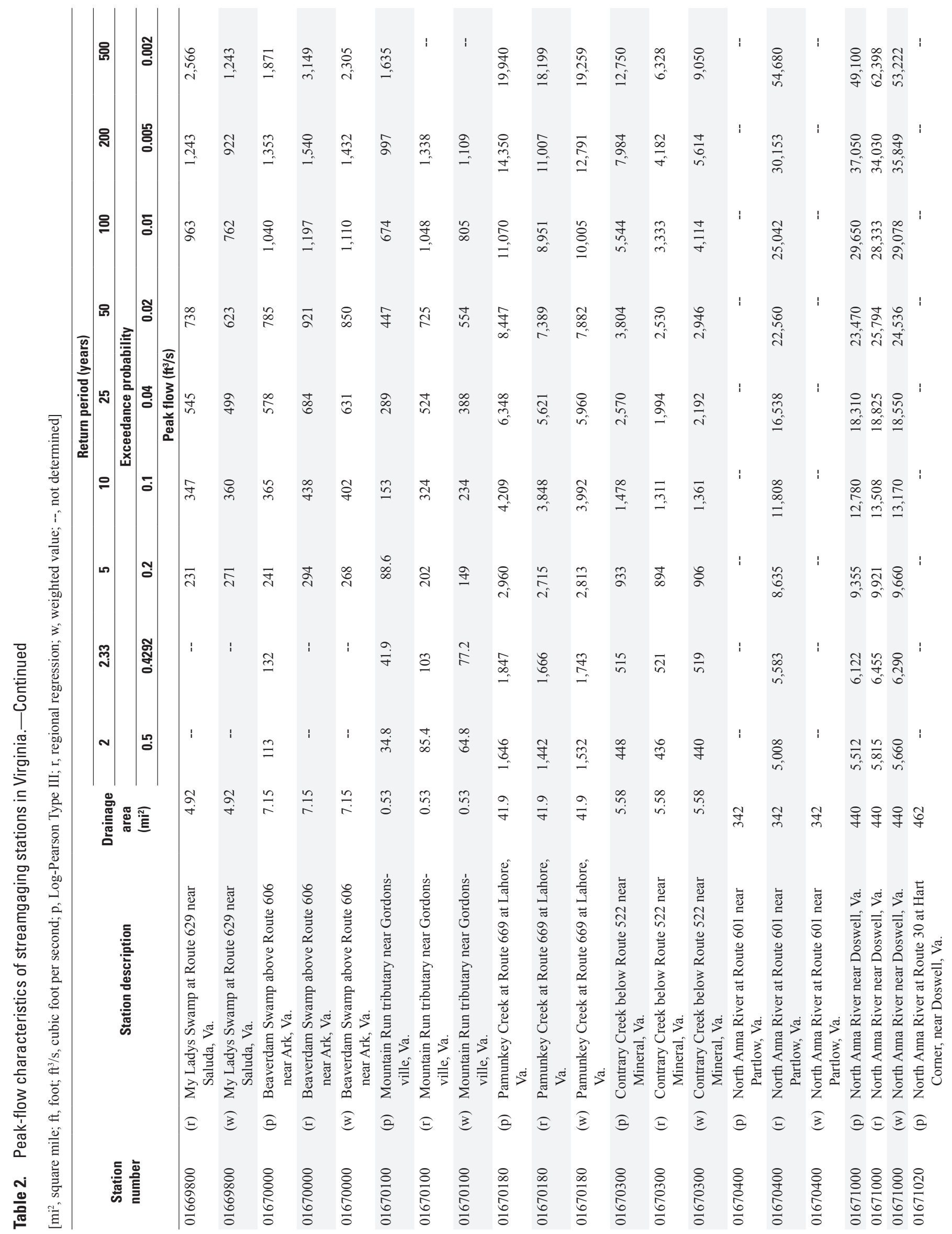




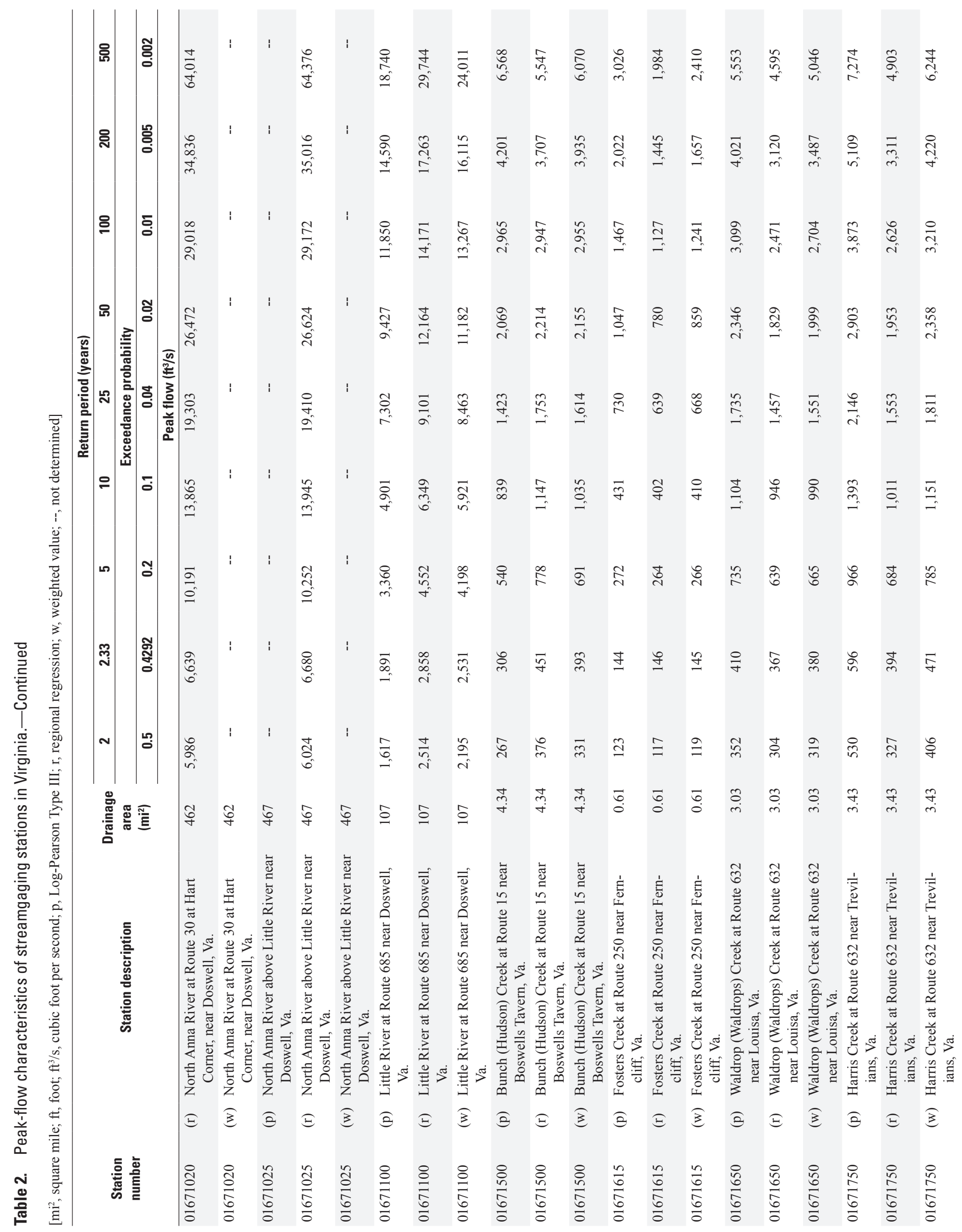




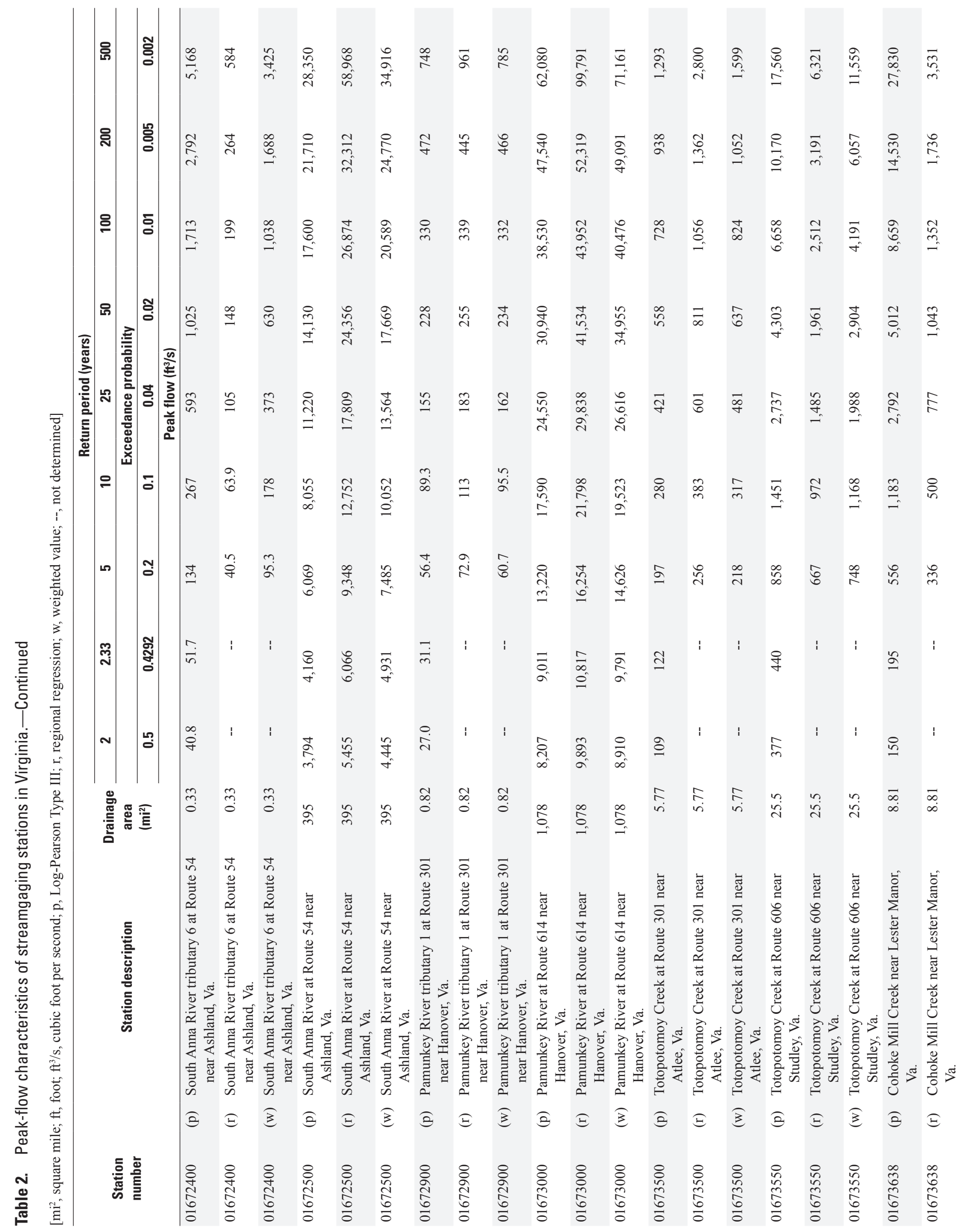




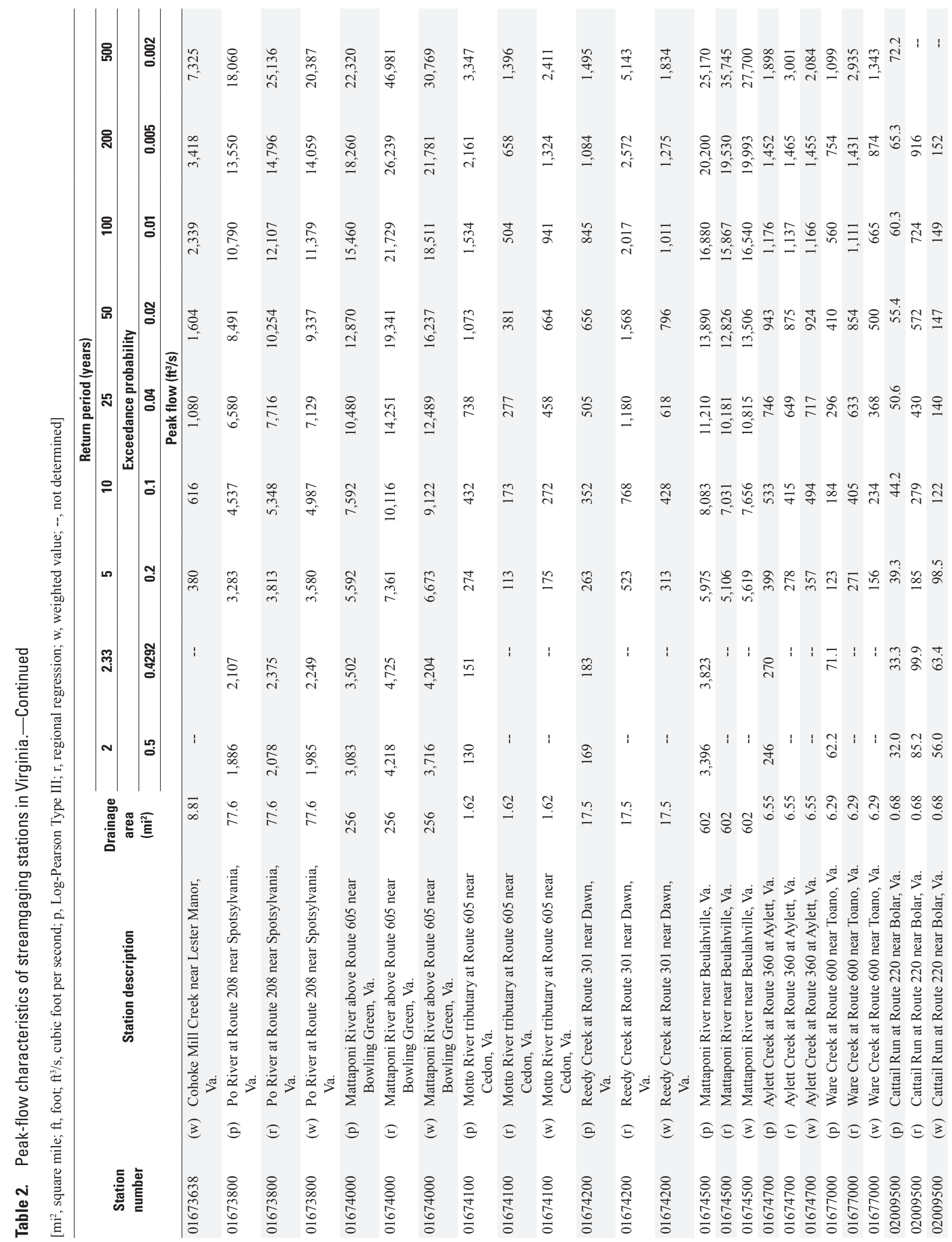




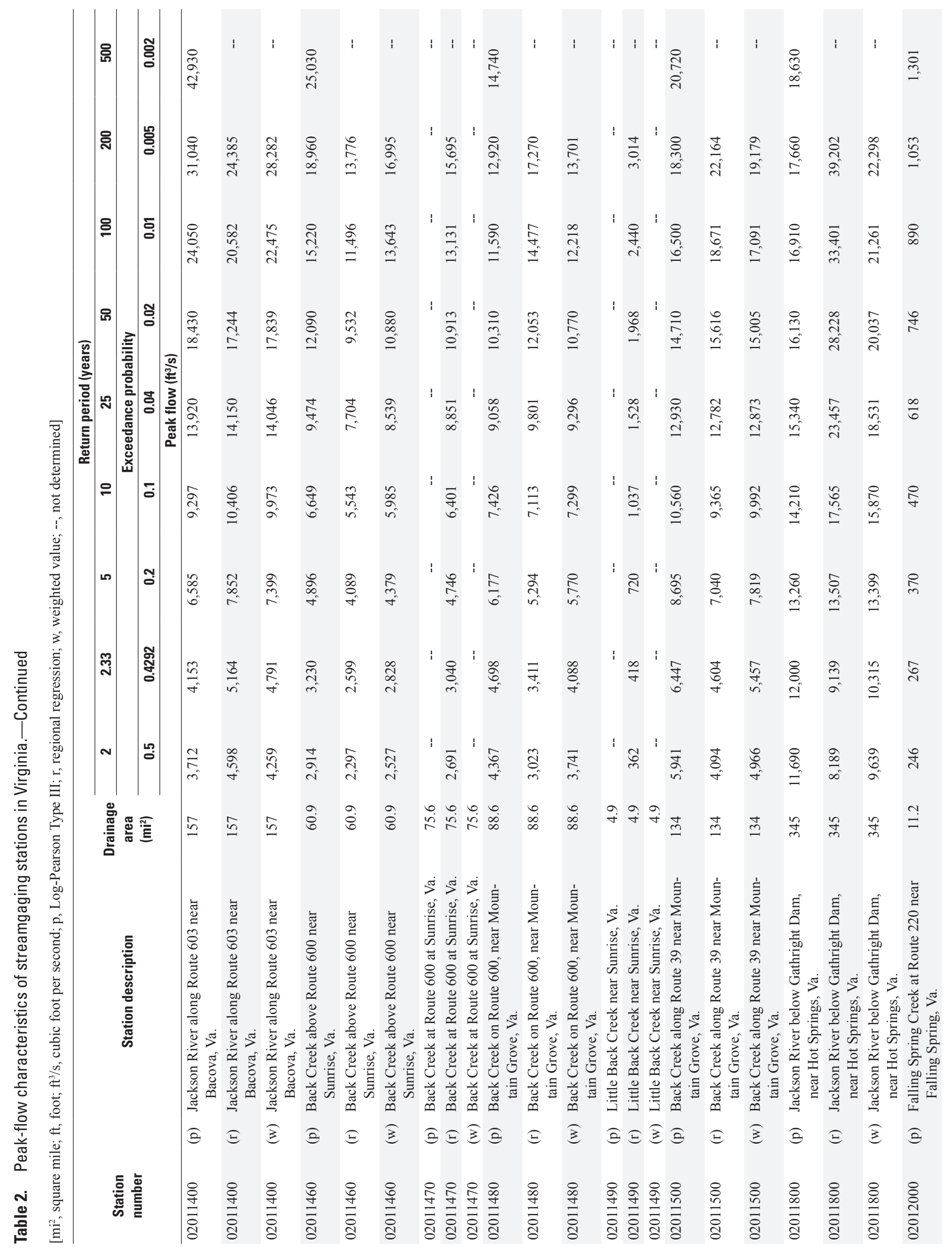




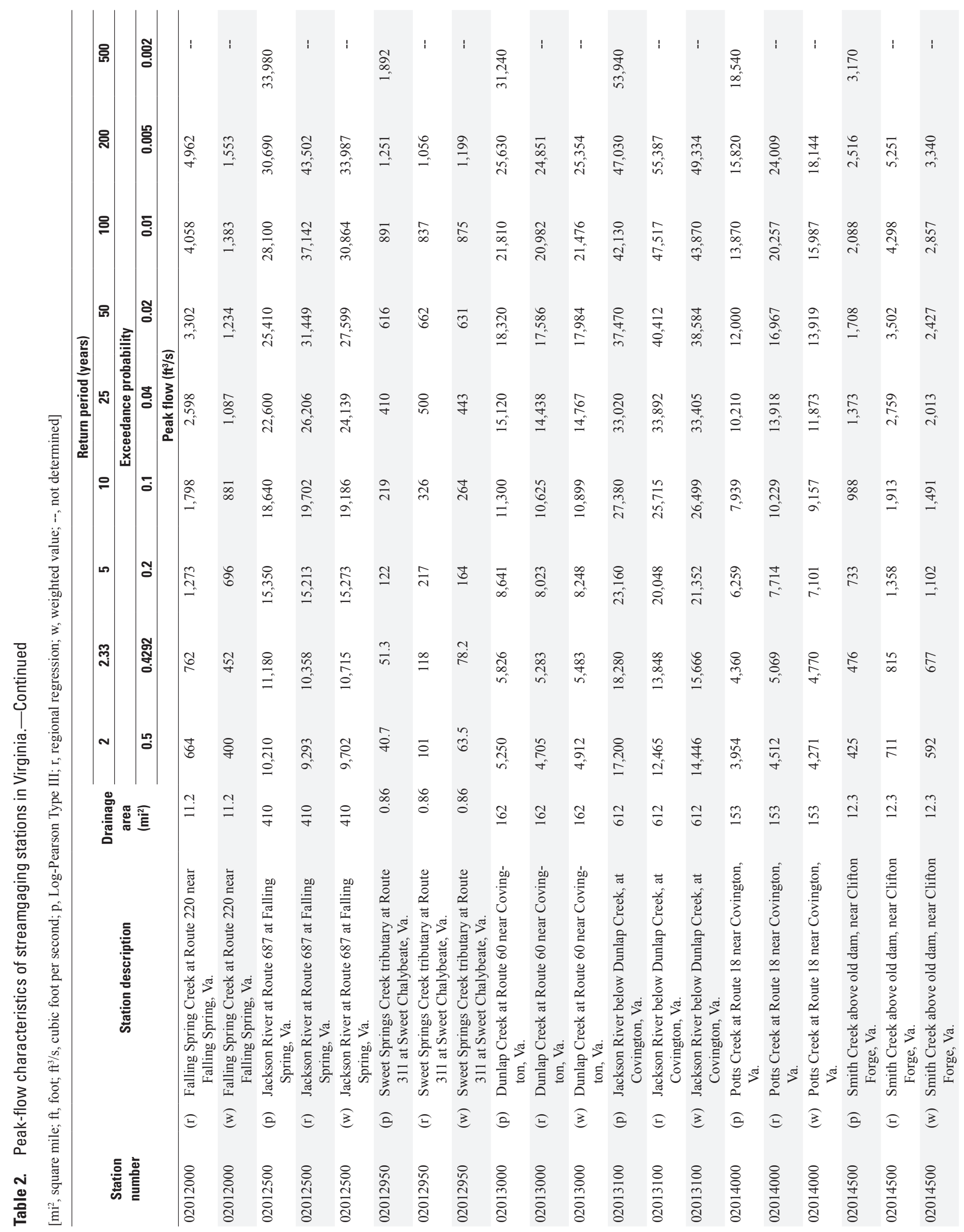




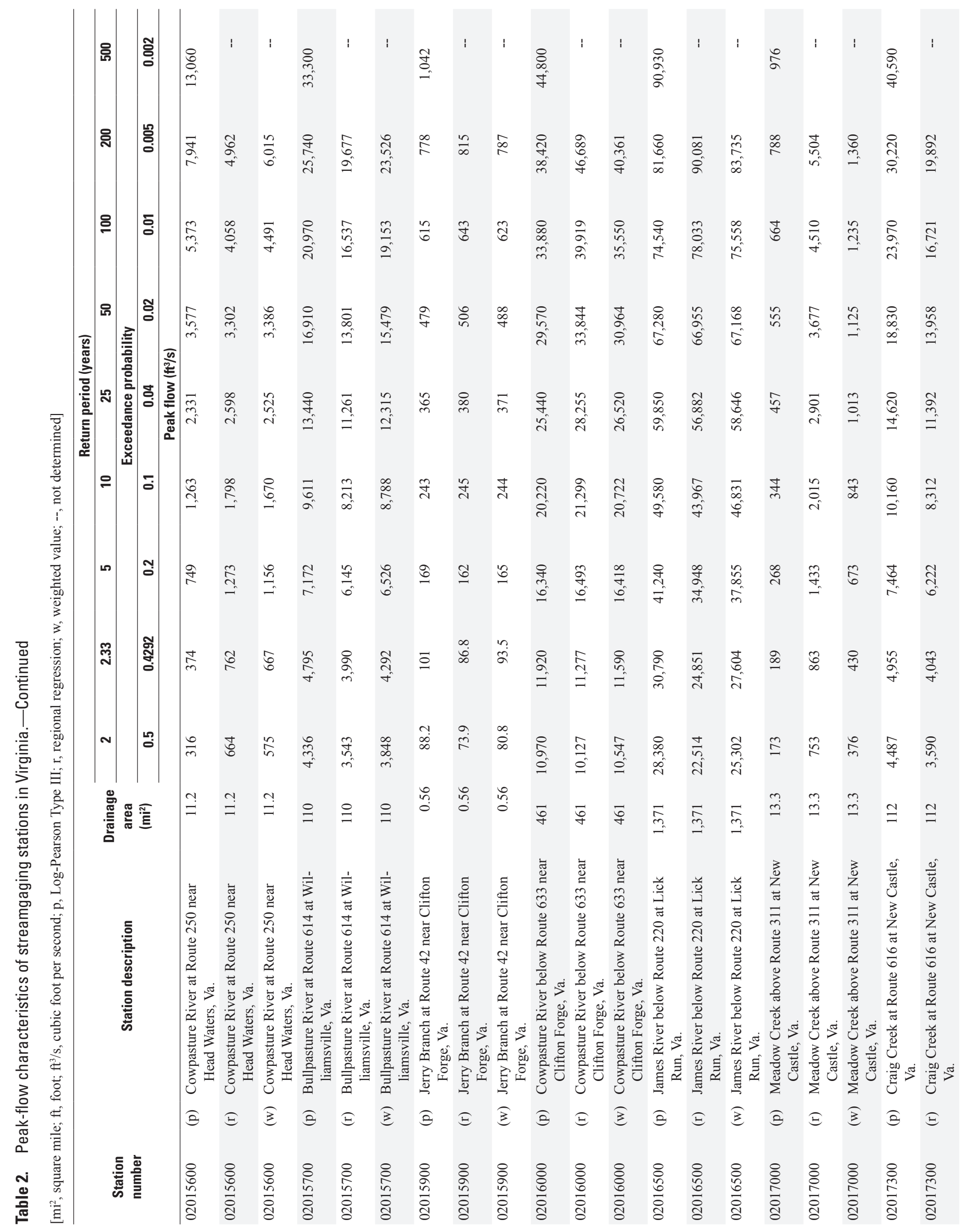




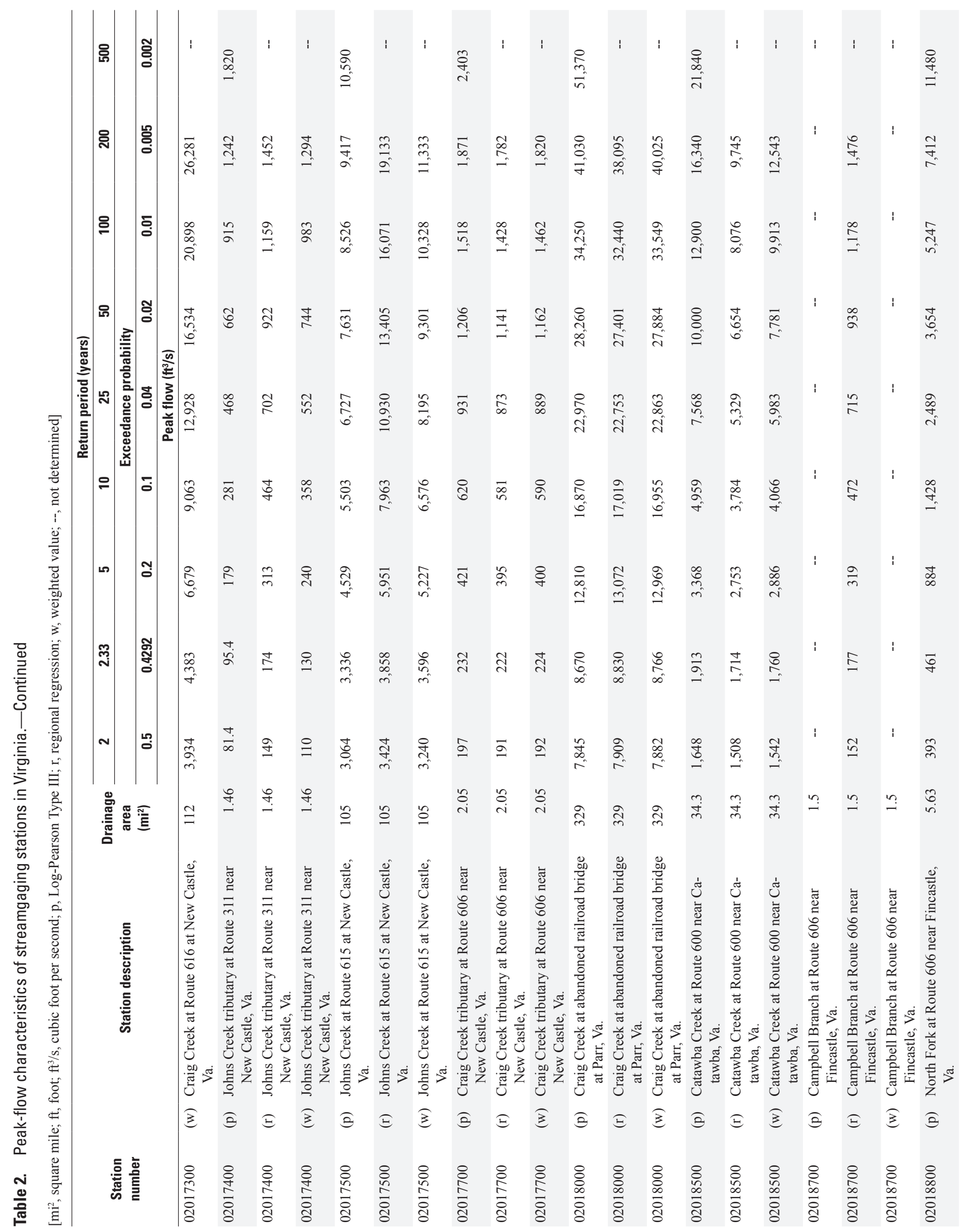




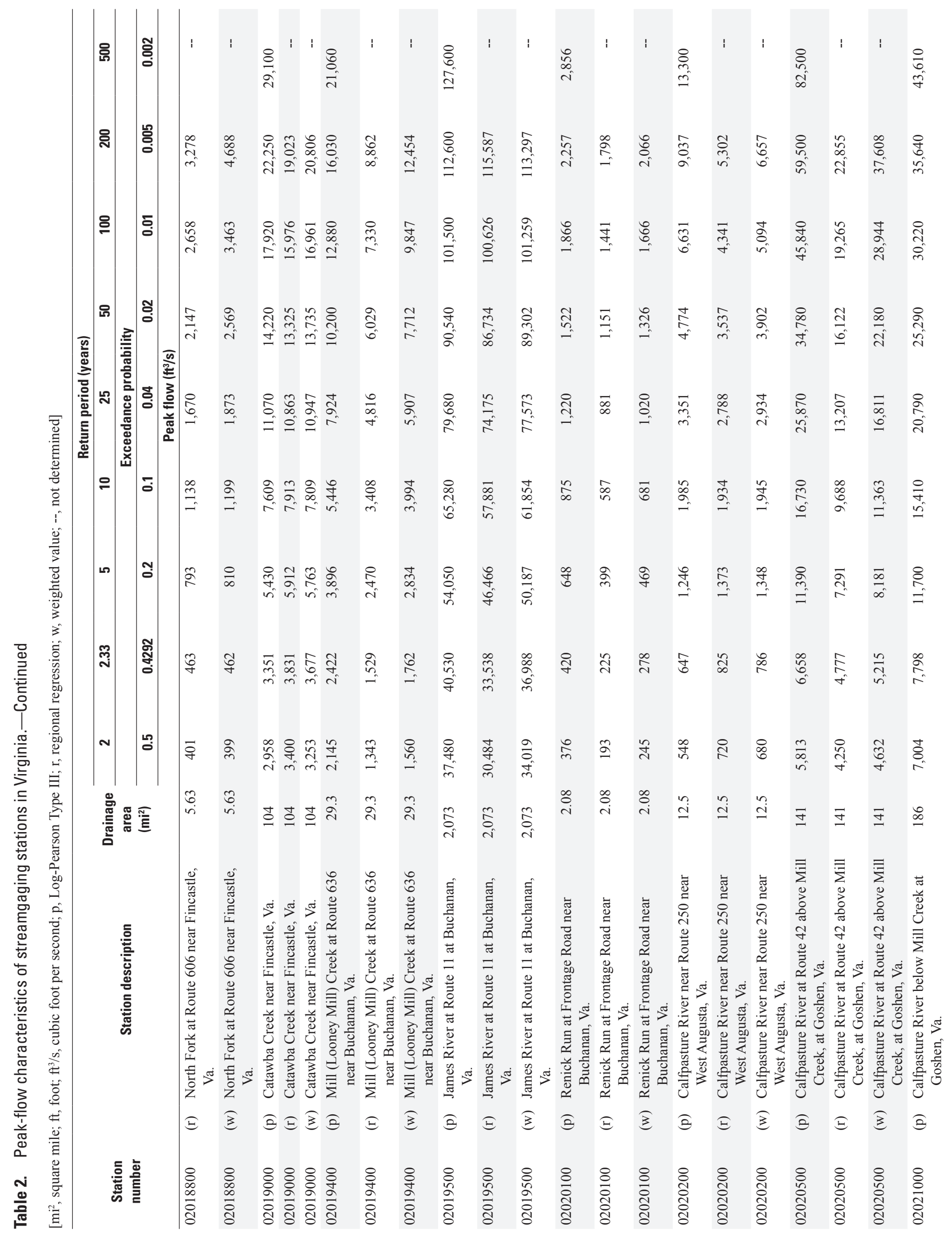




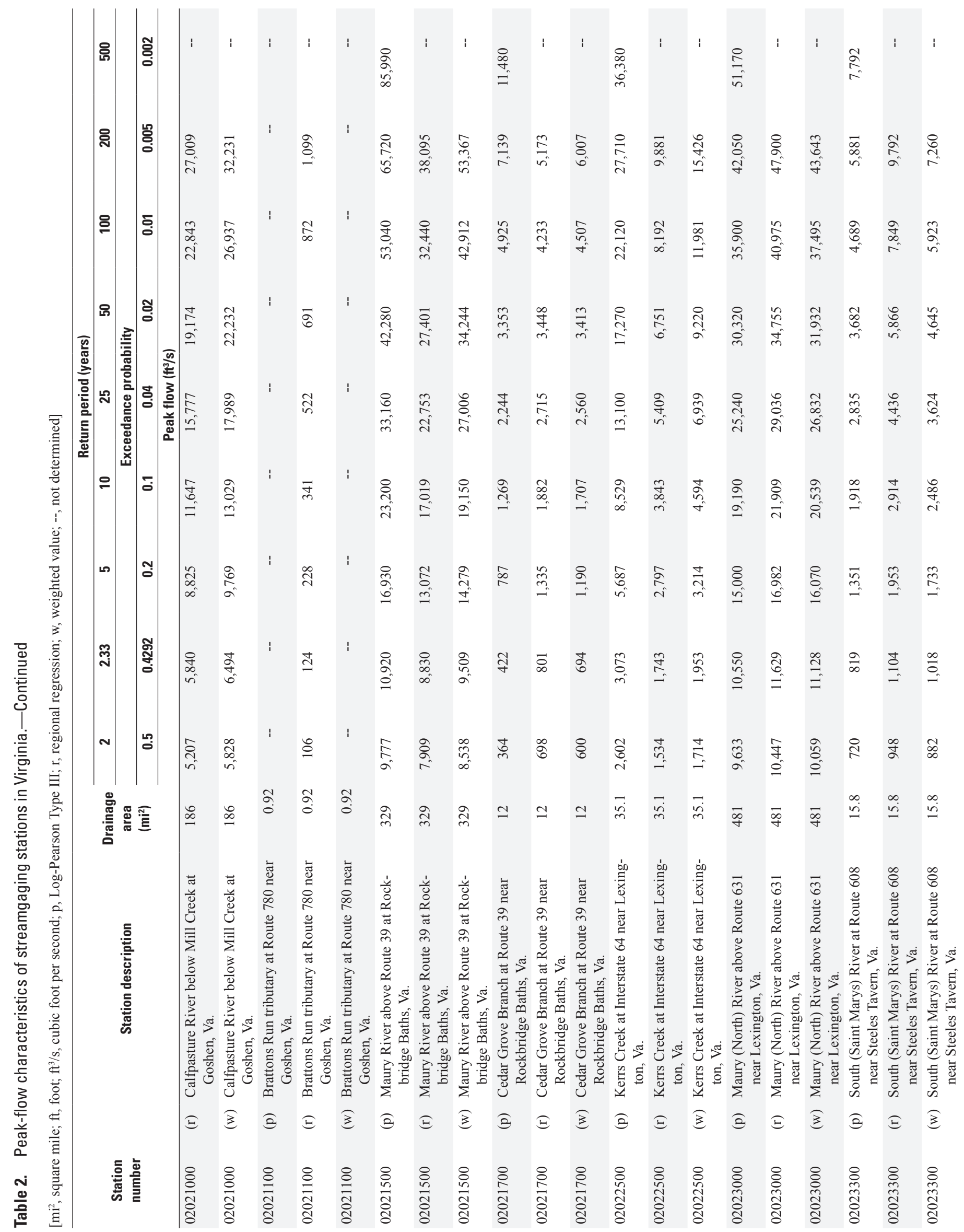




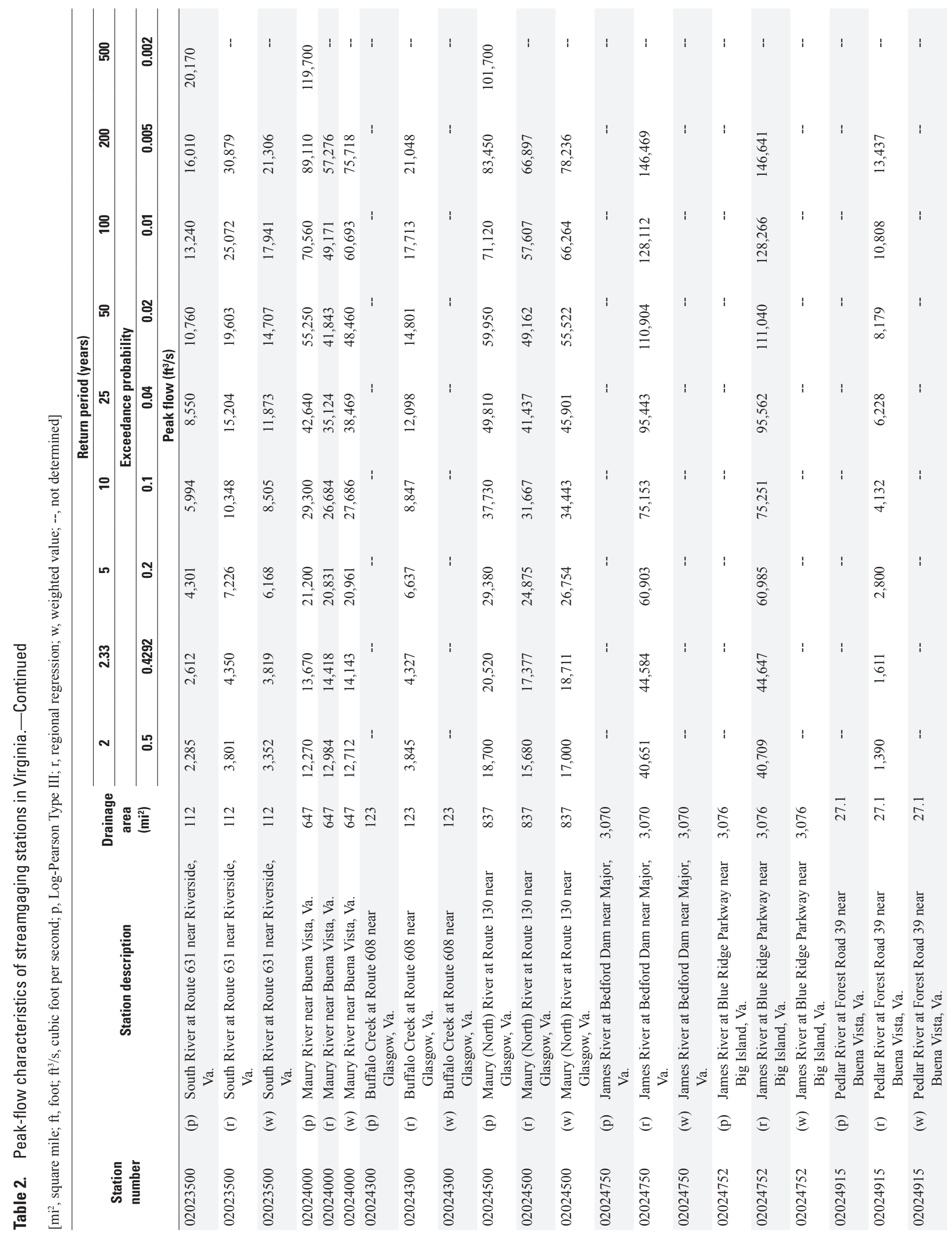




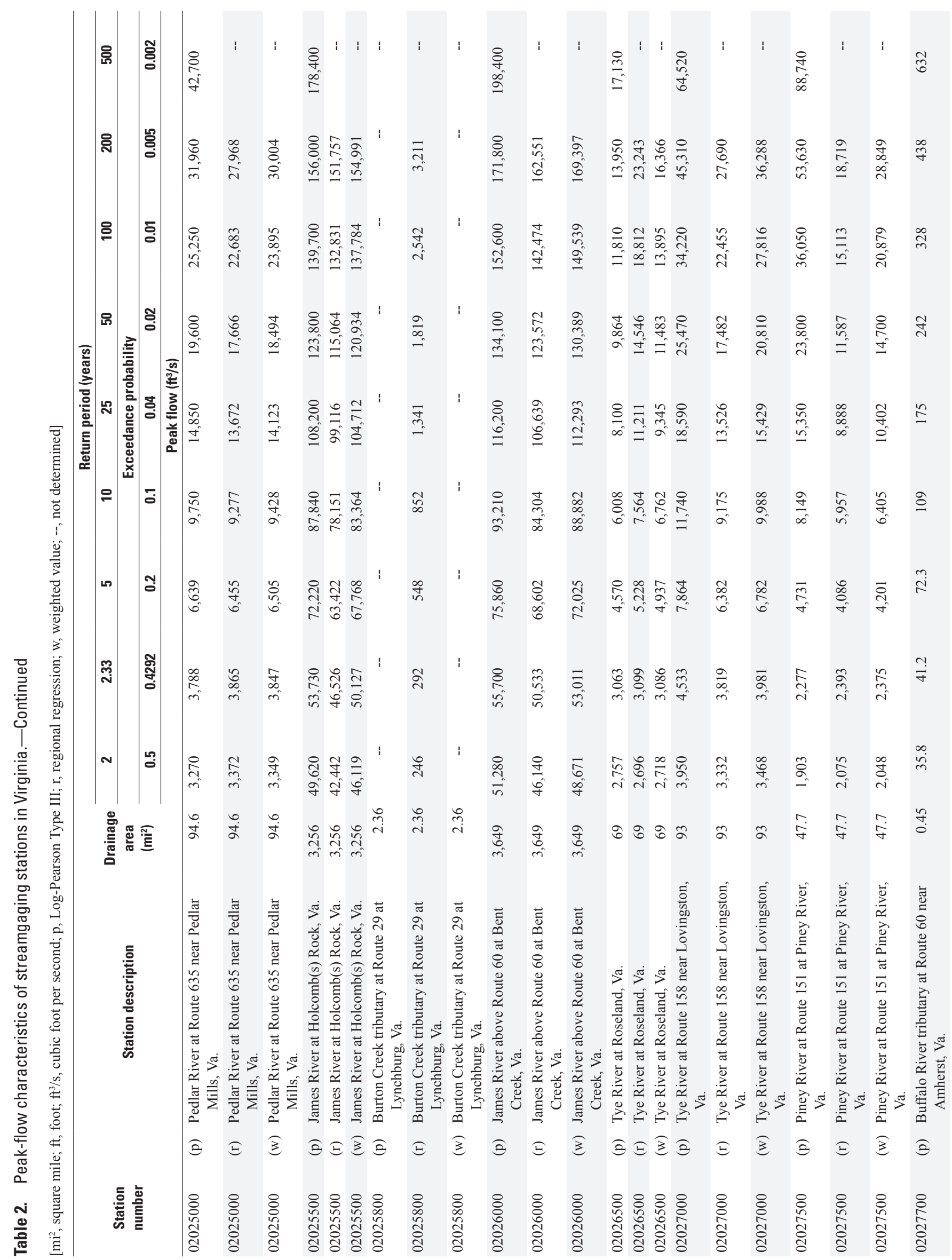




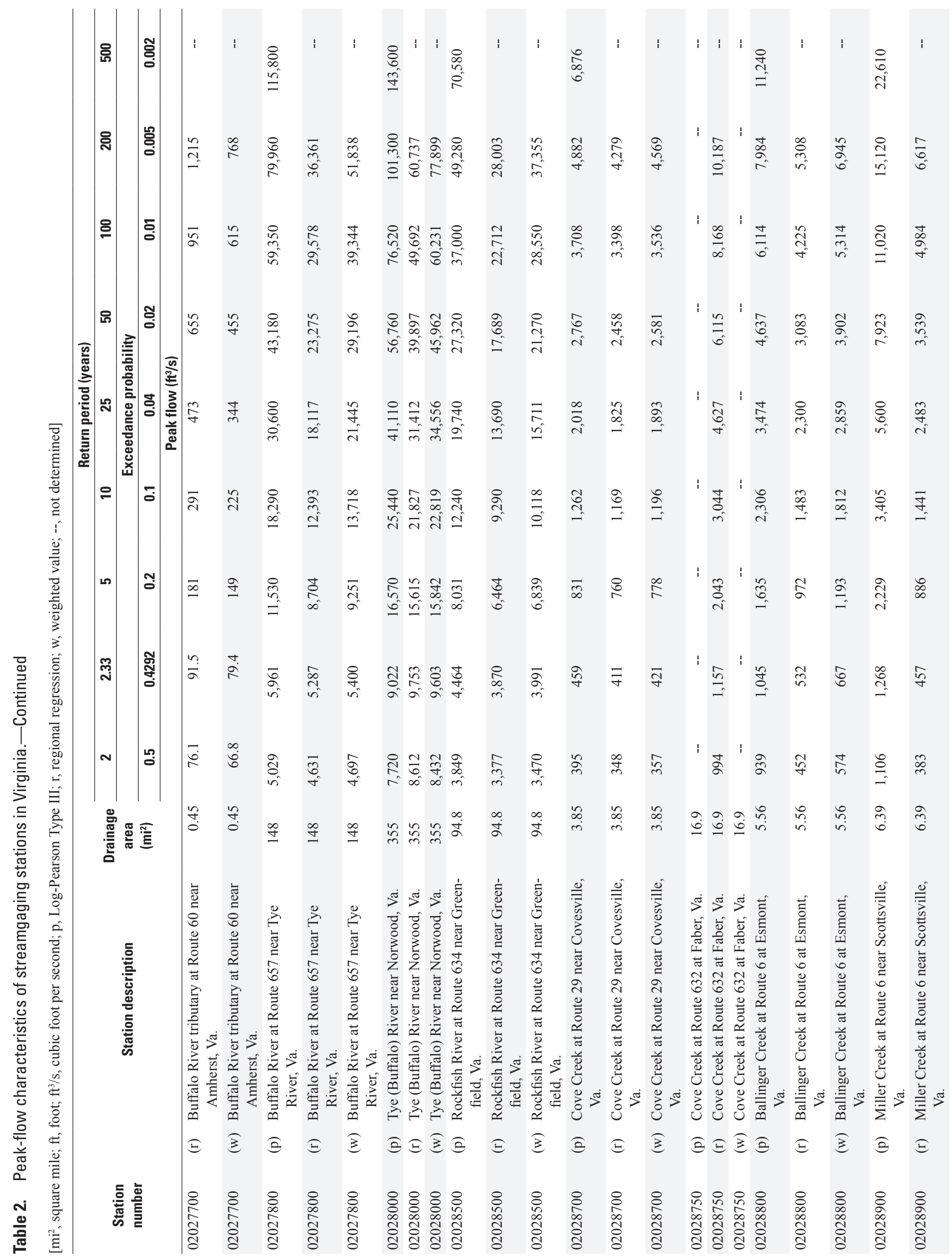




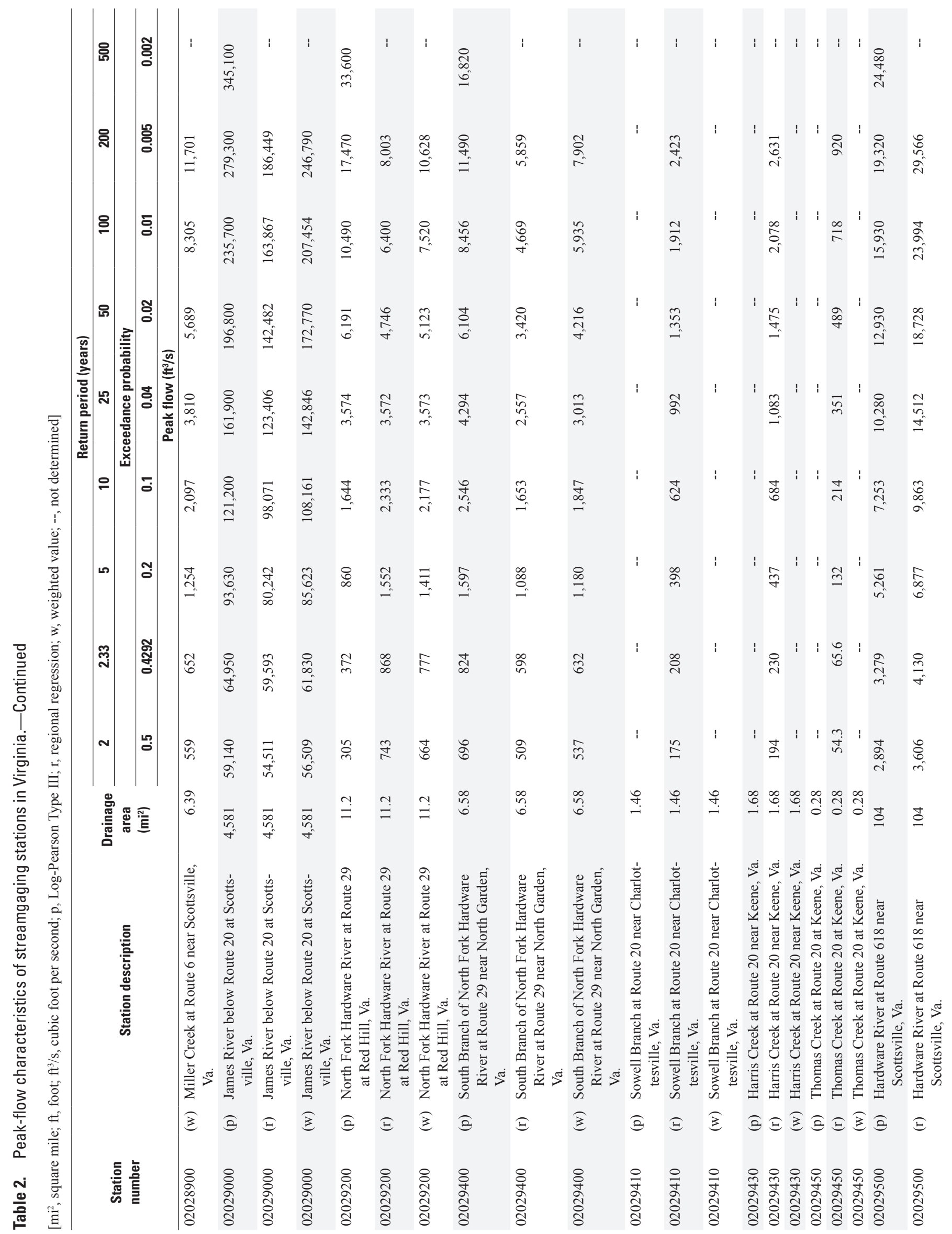




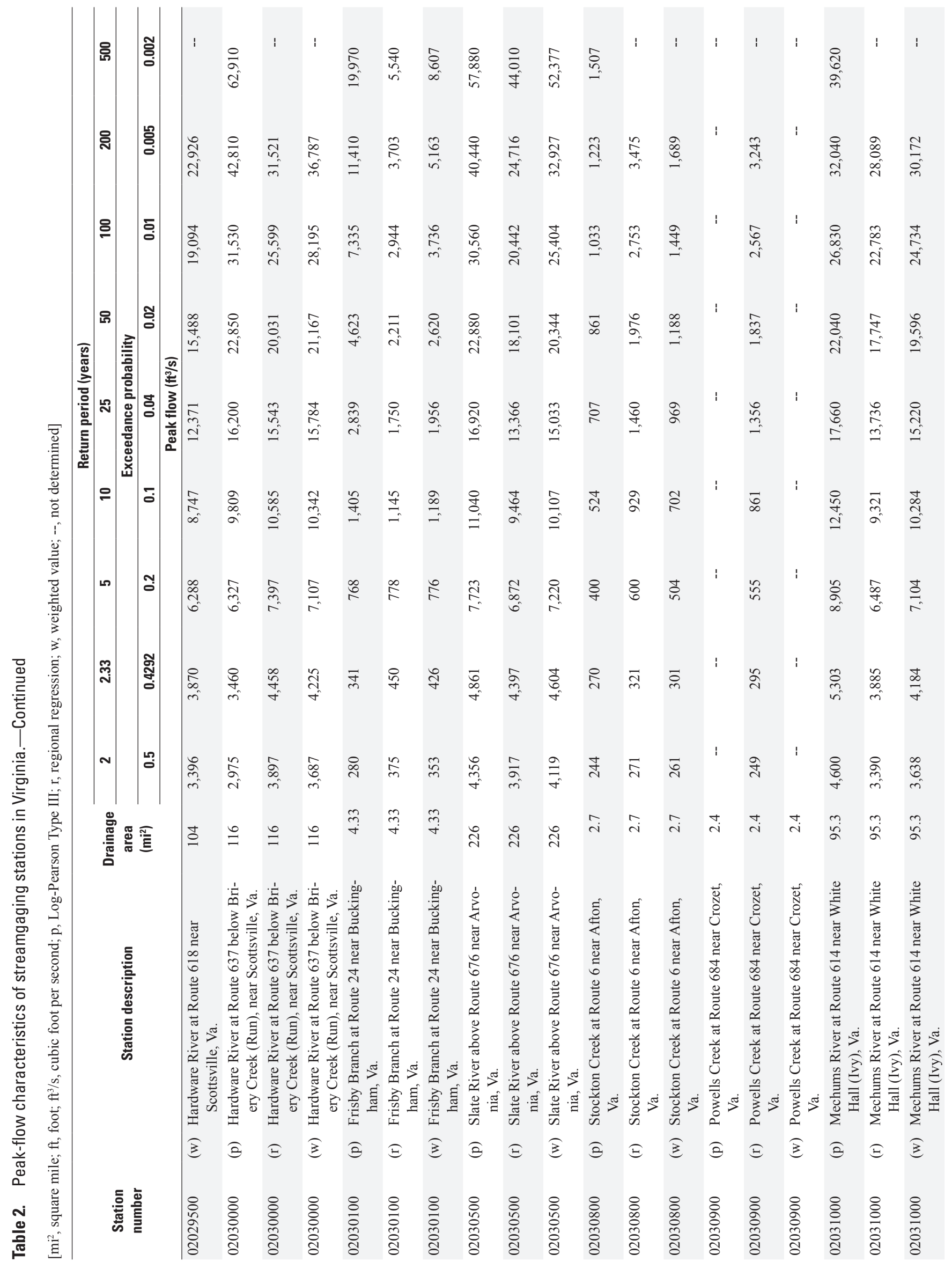




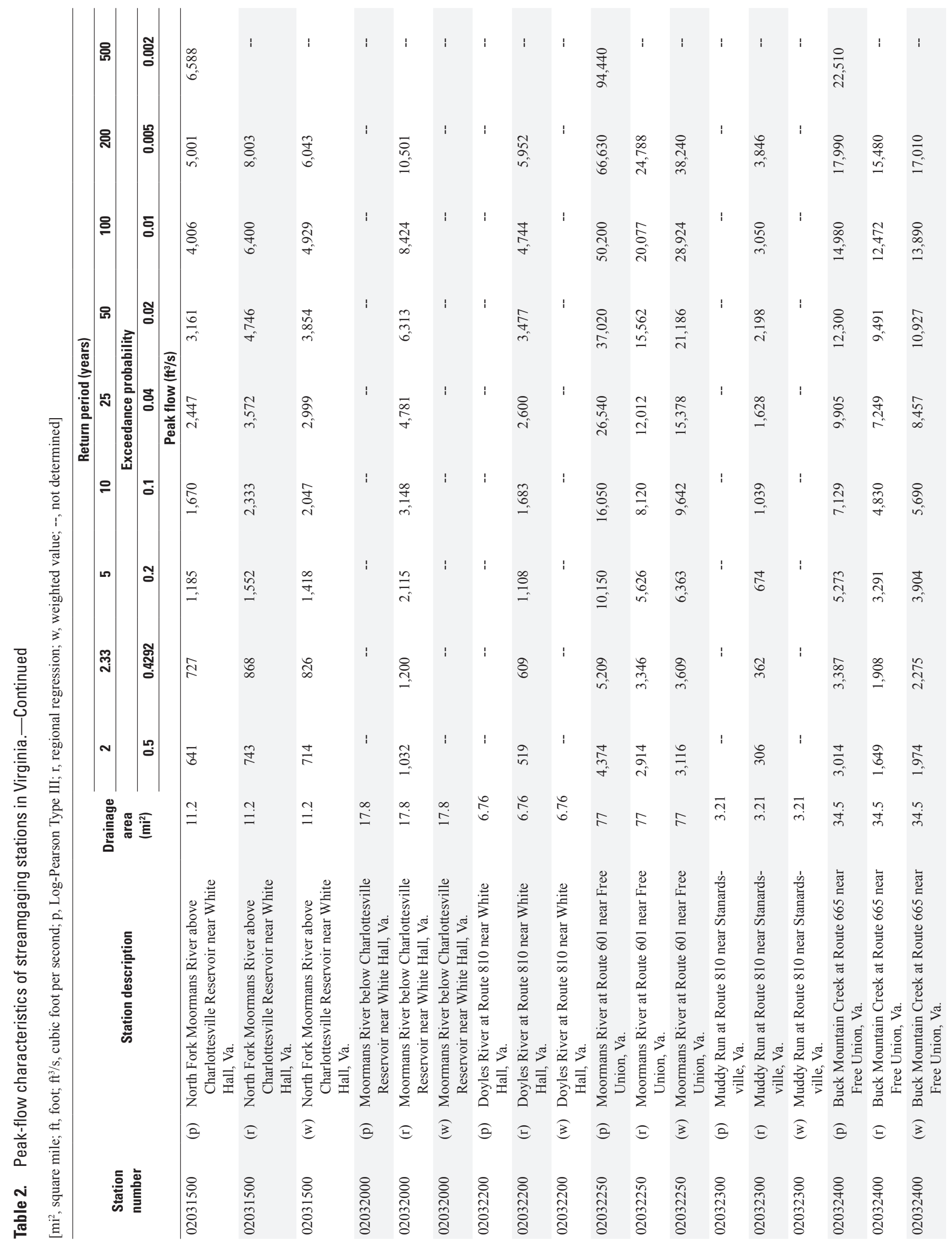




\section{7}

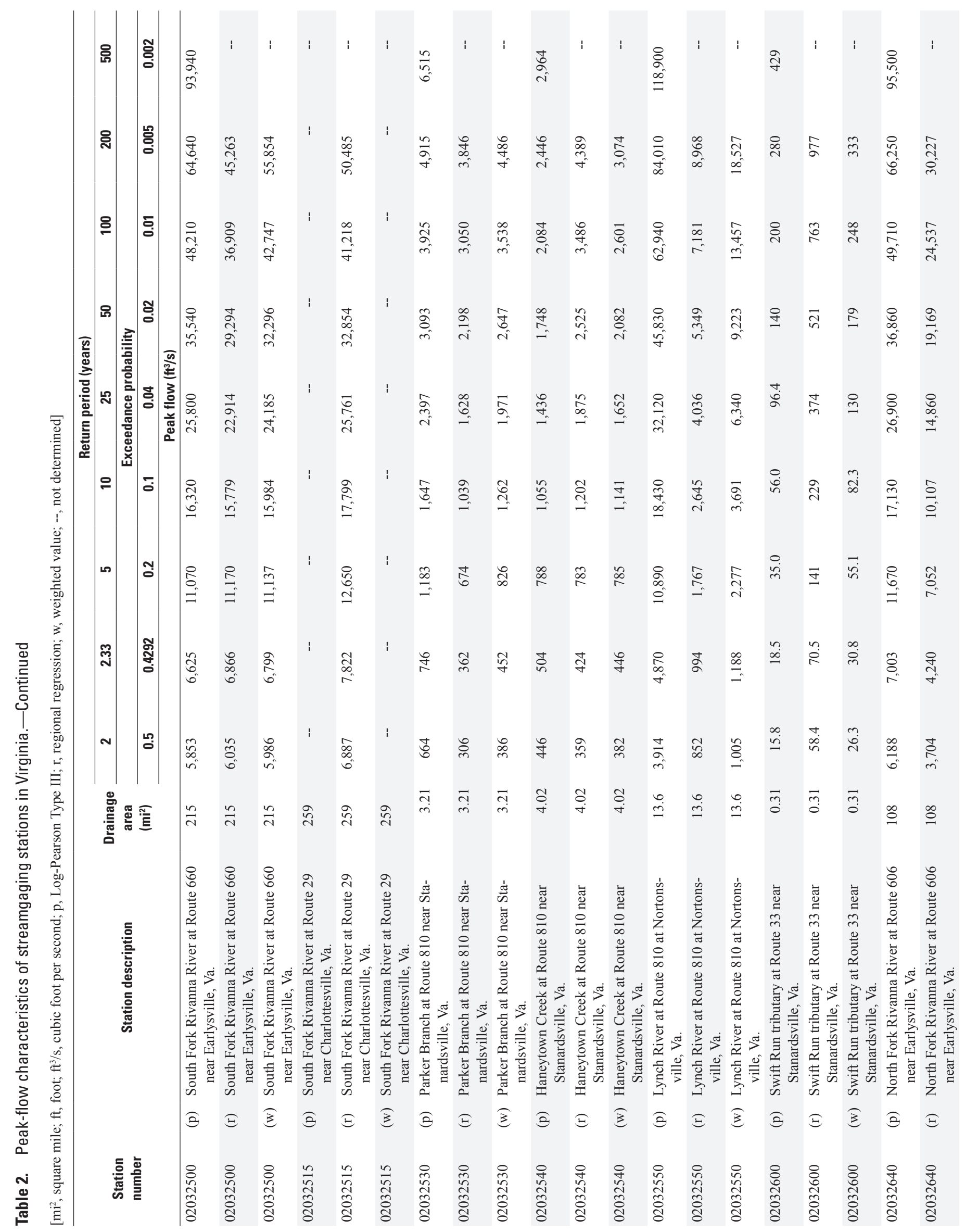




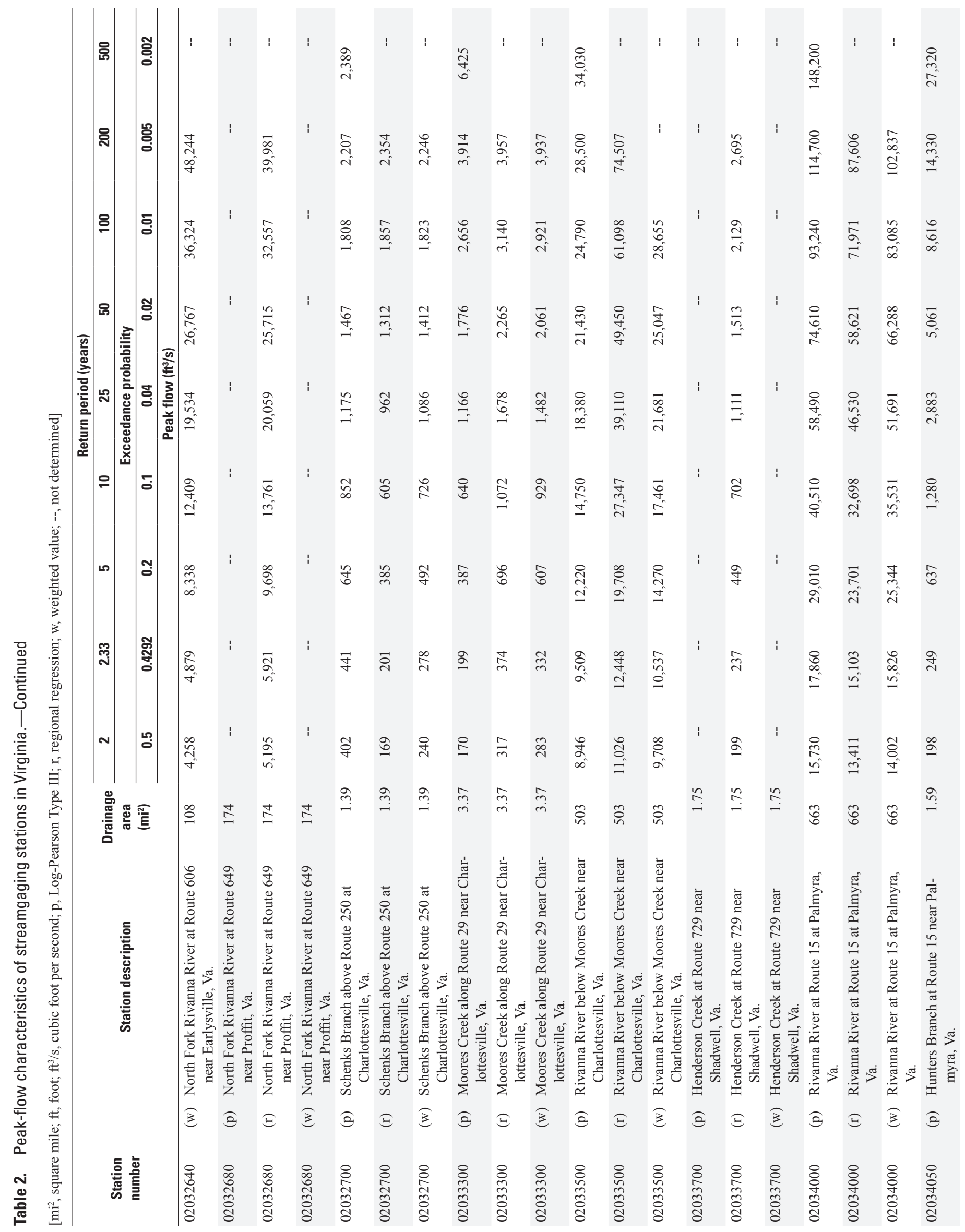




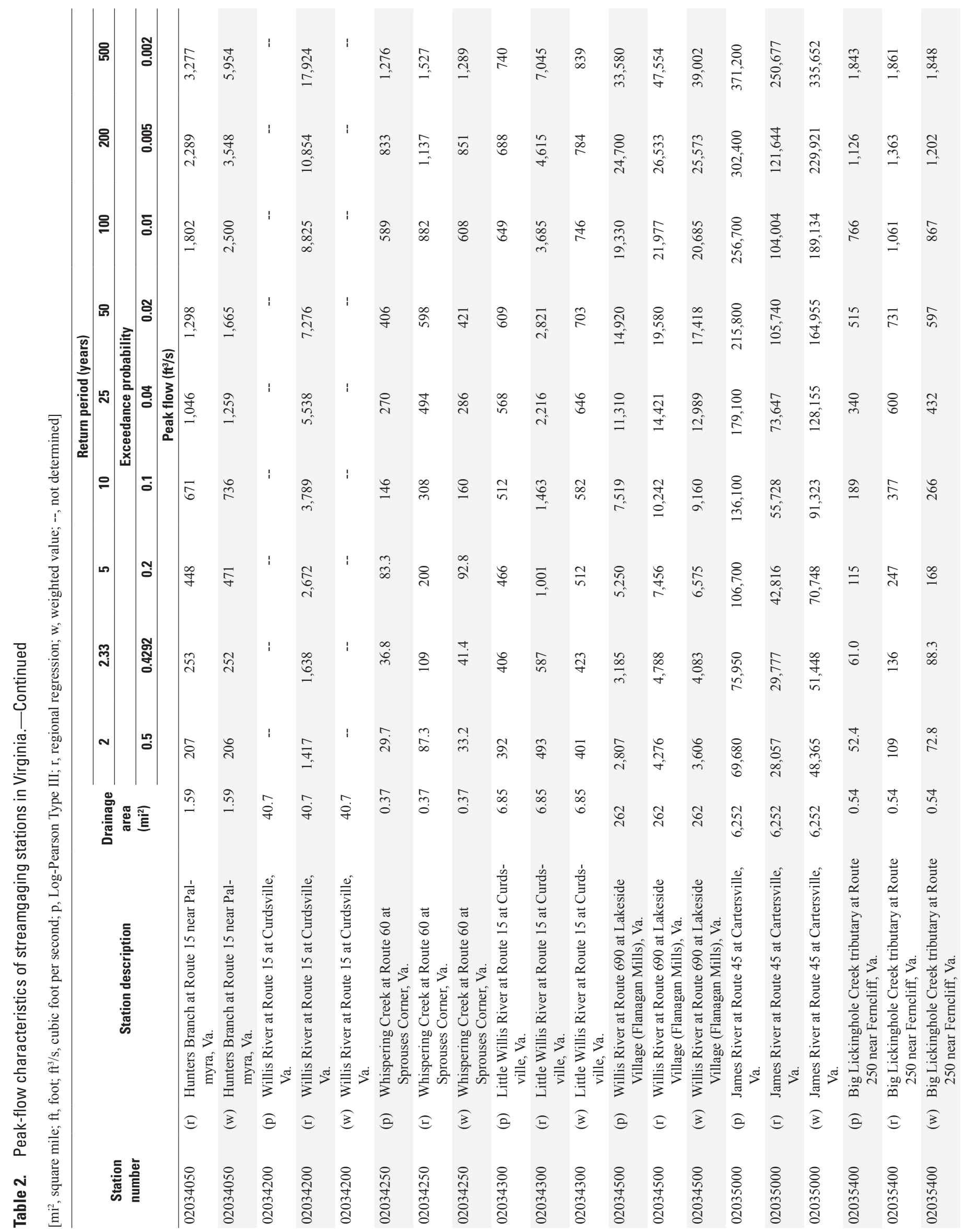




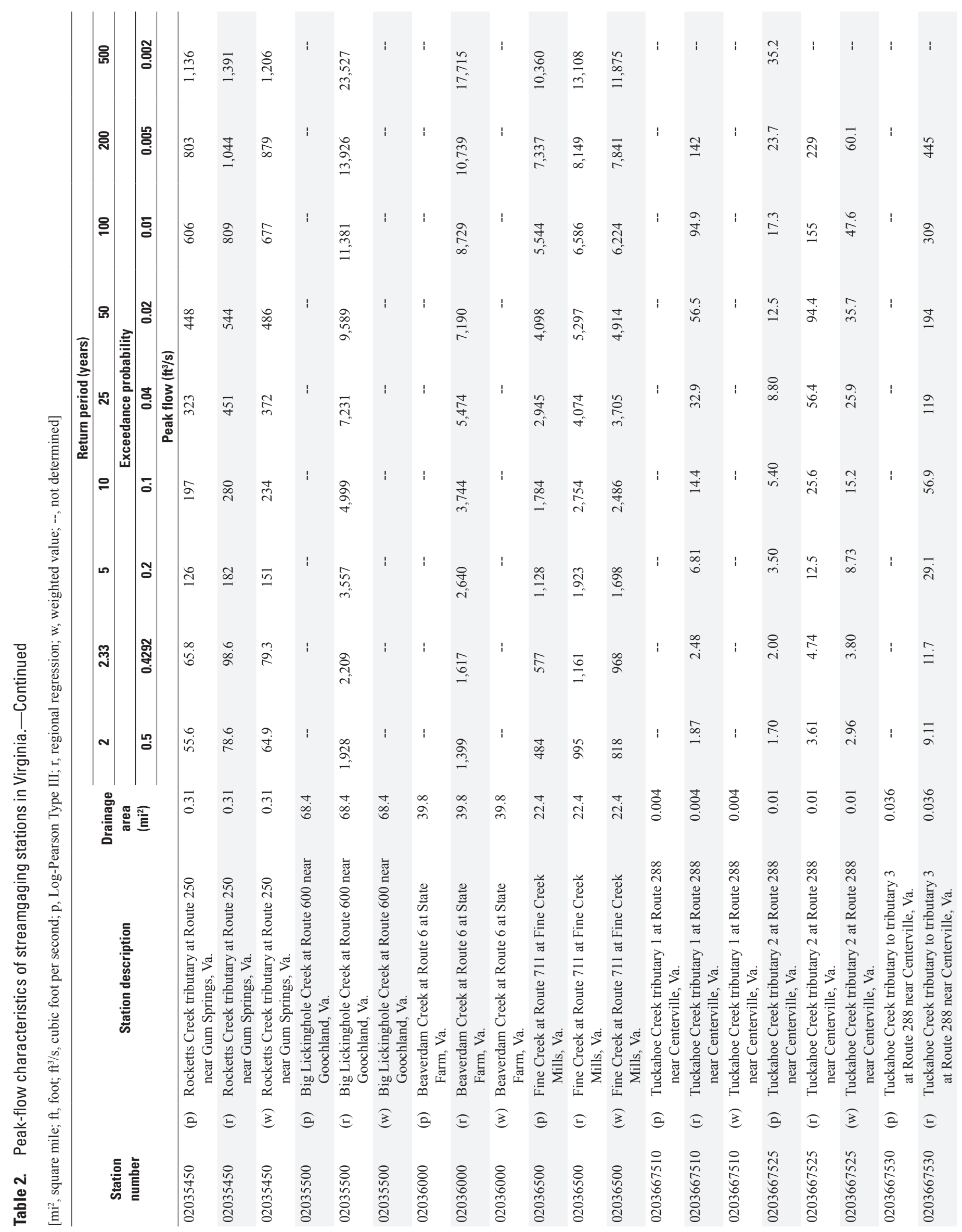




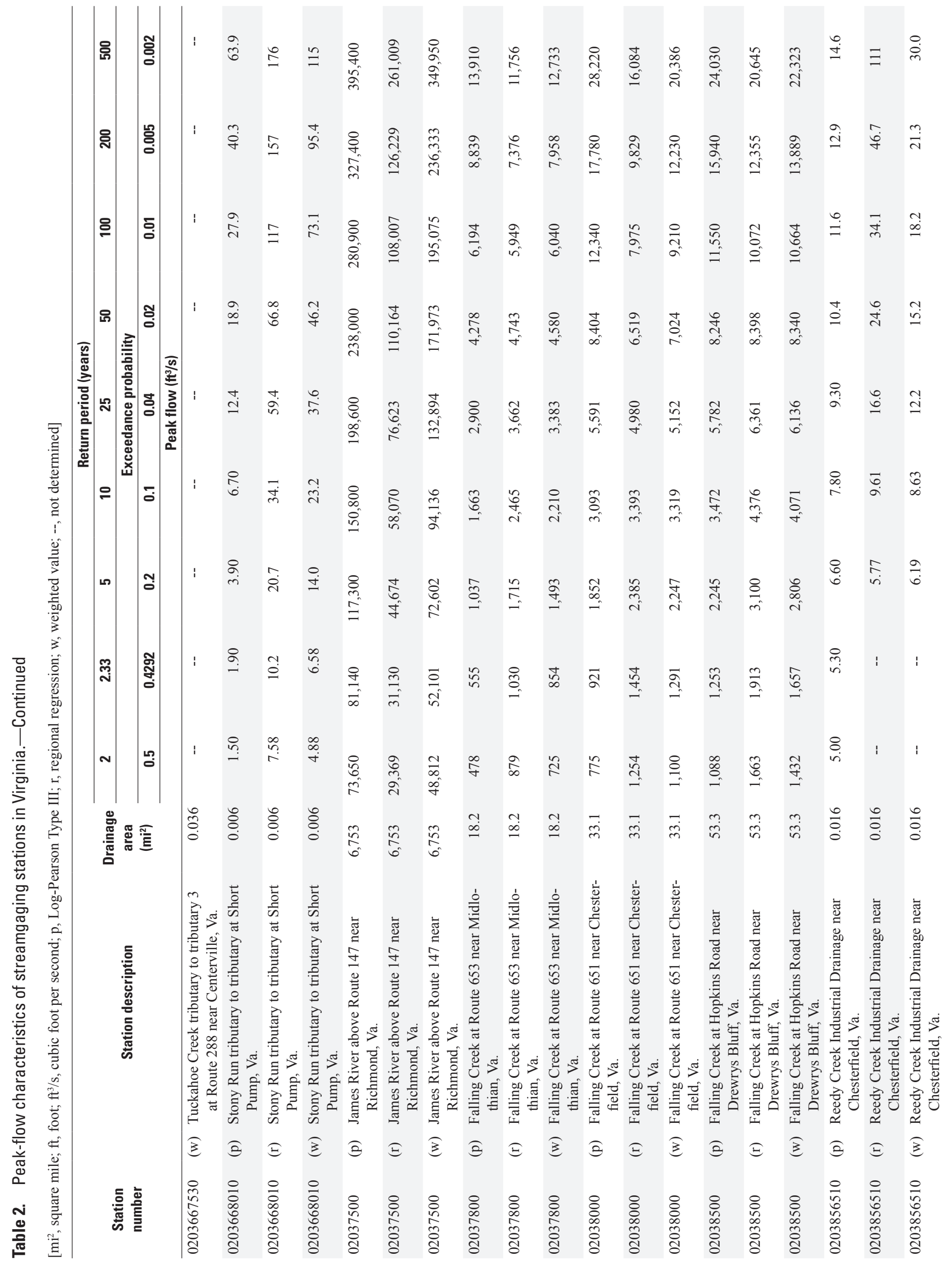




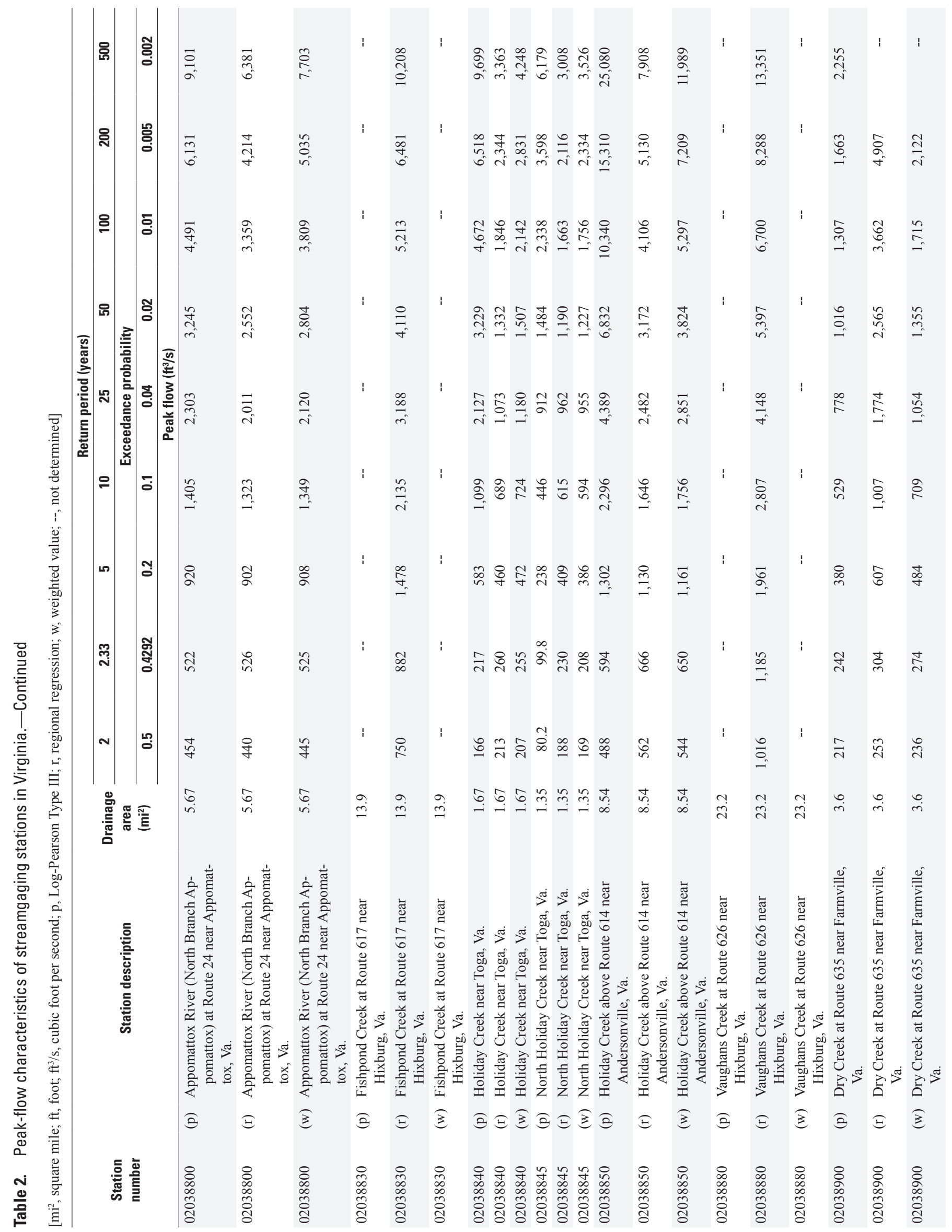




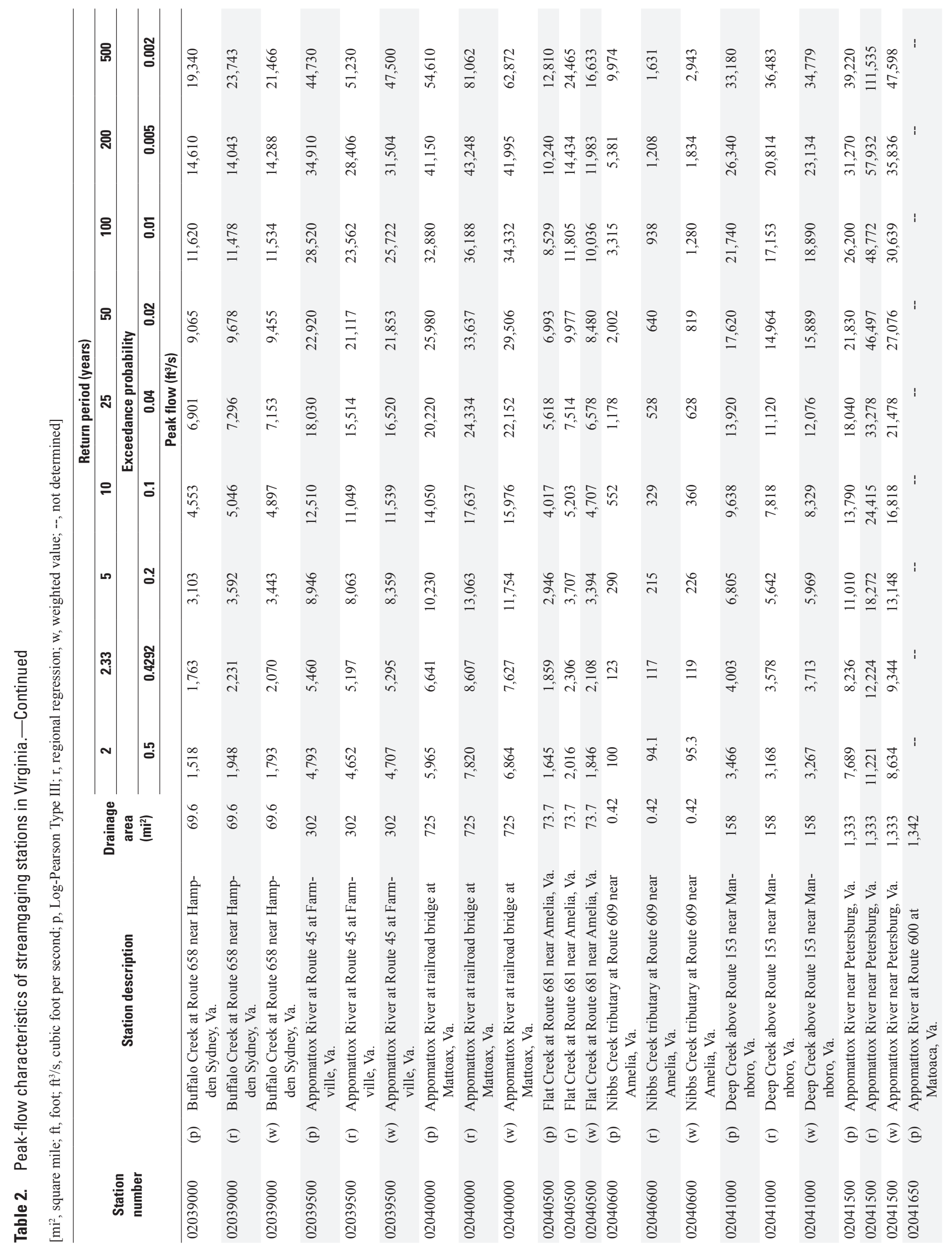




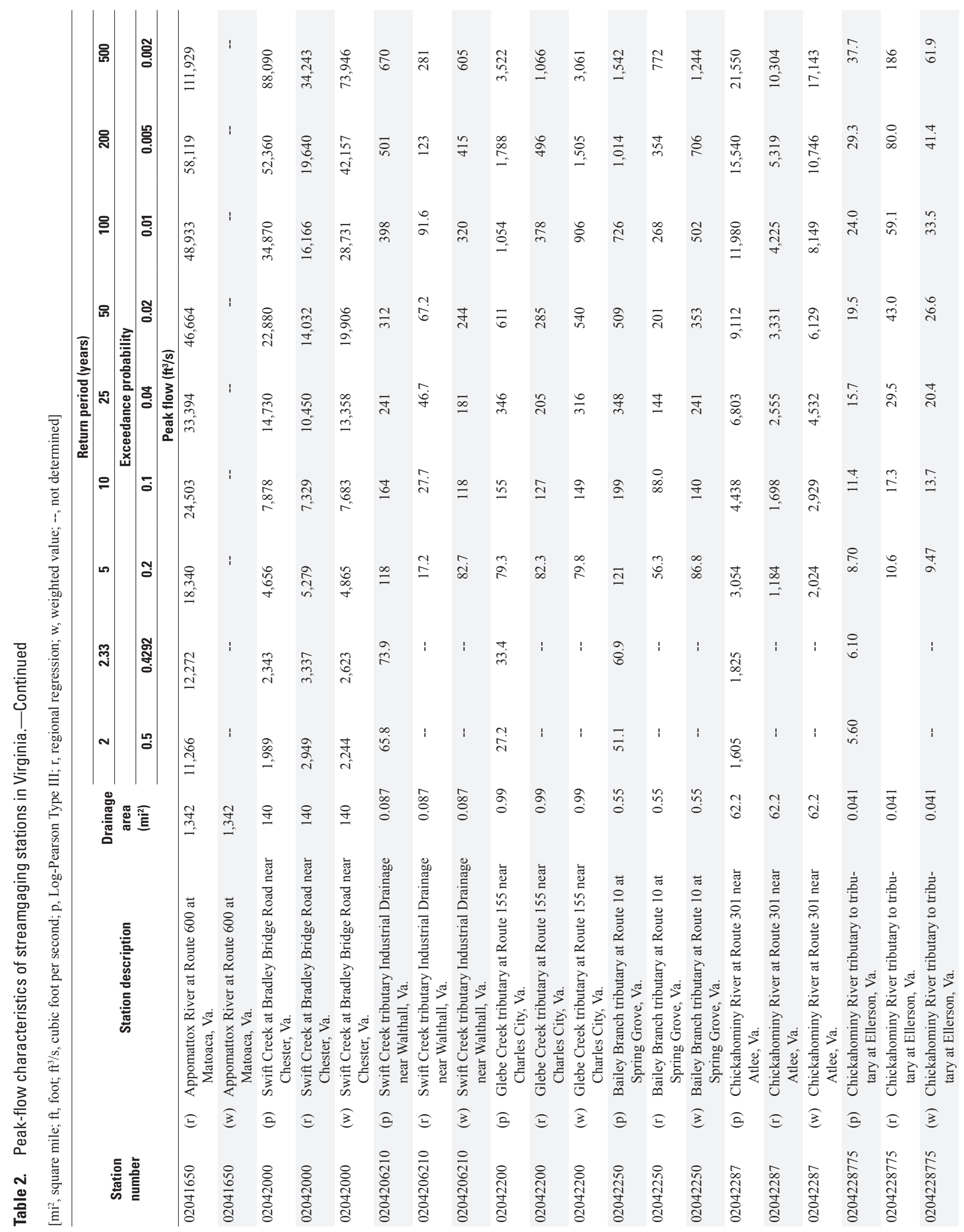




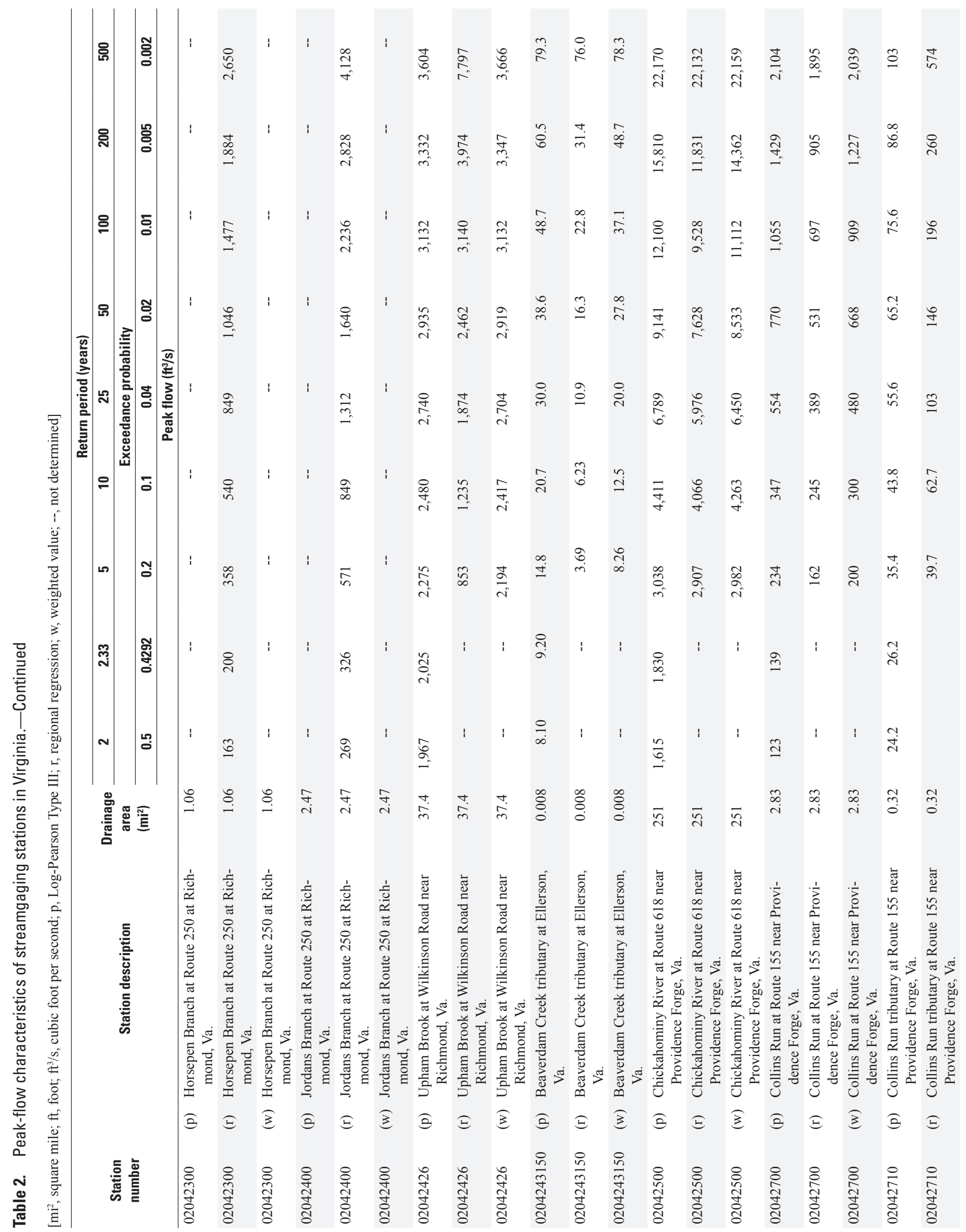




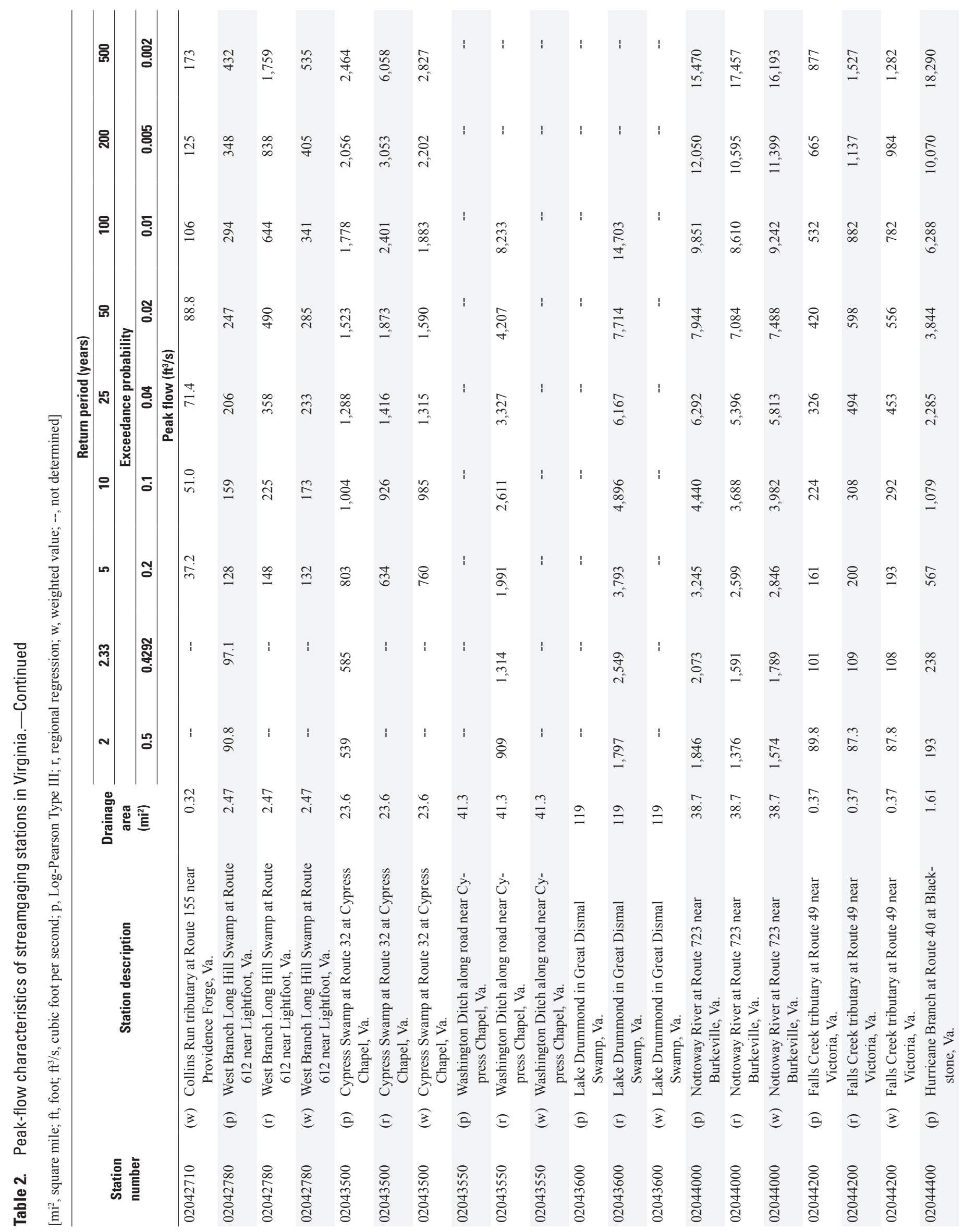




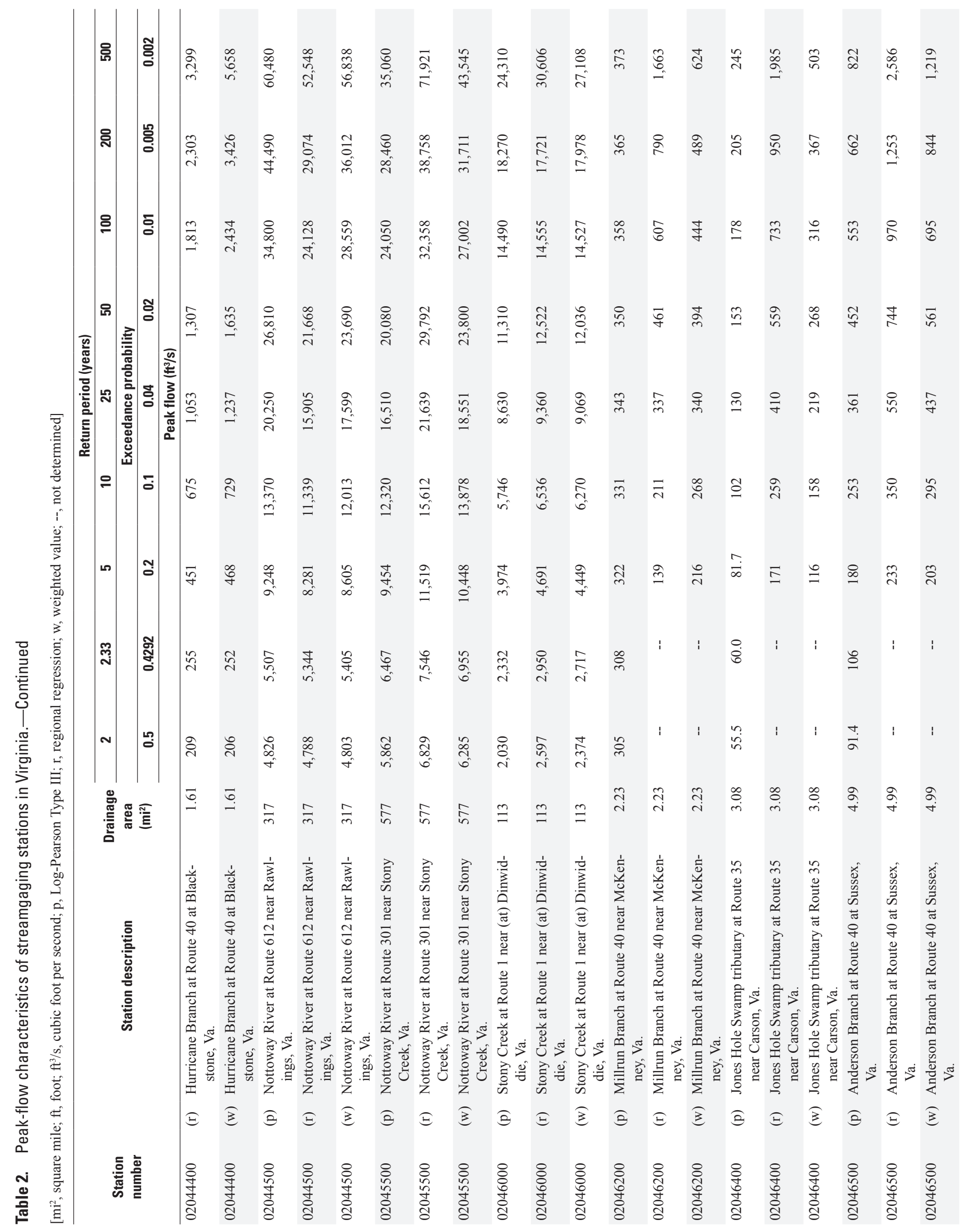




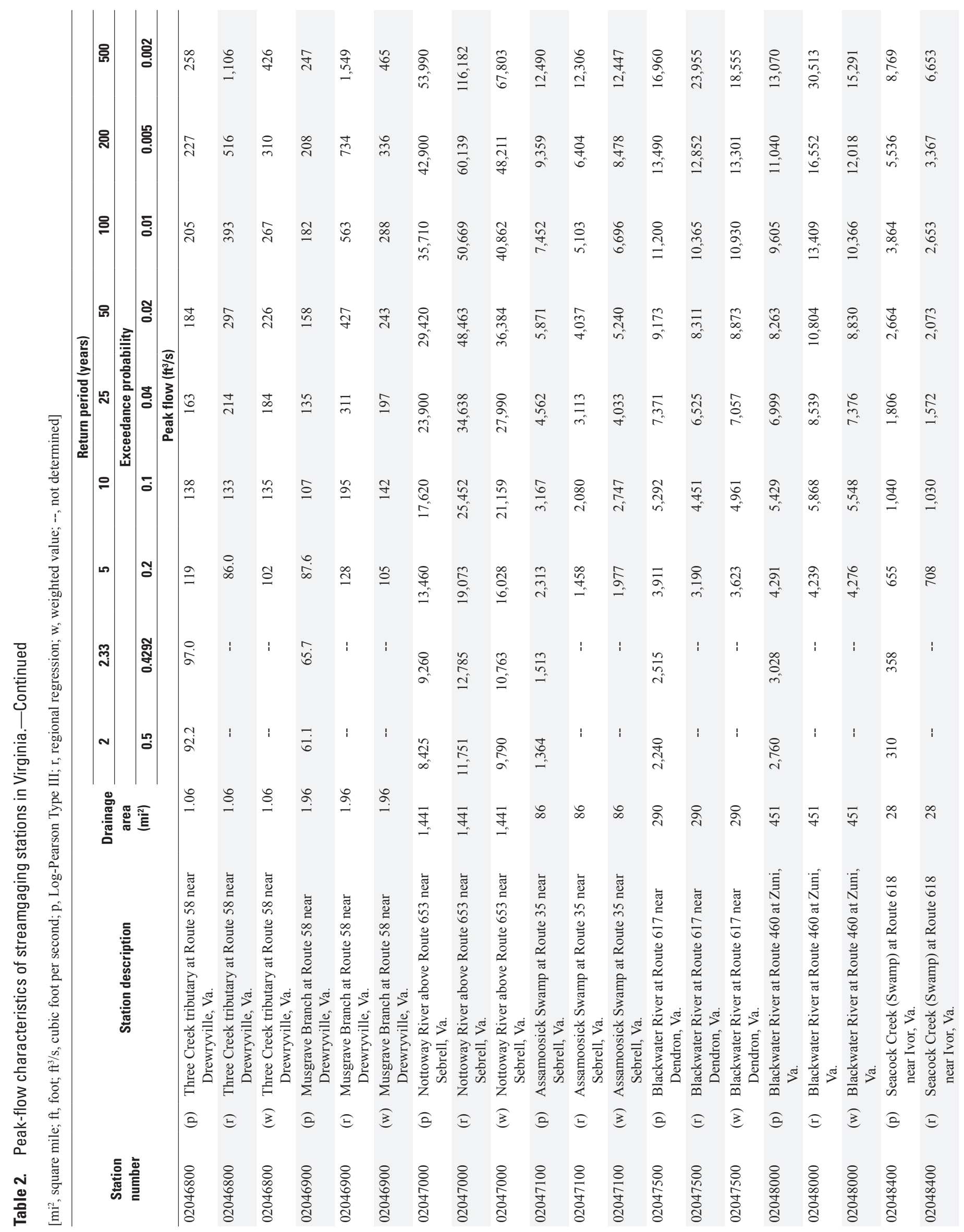




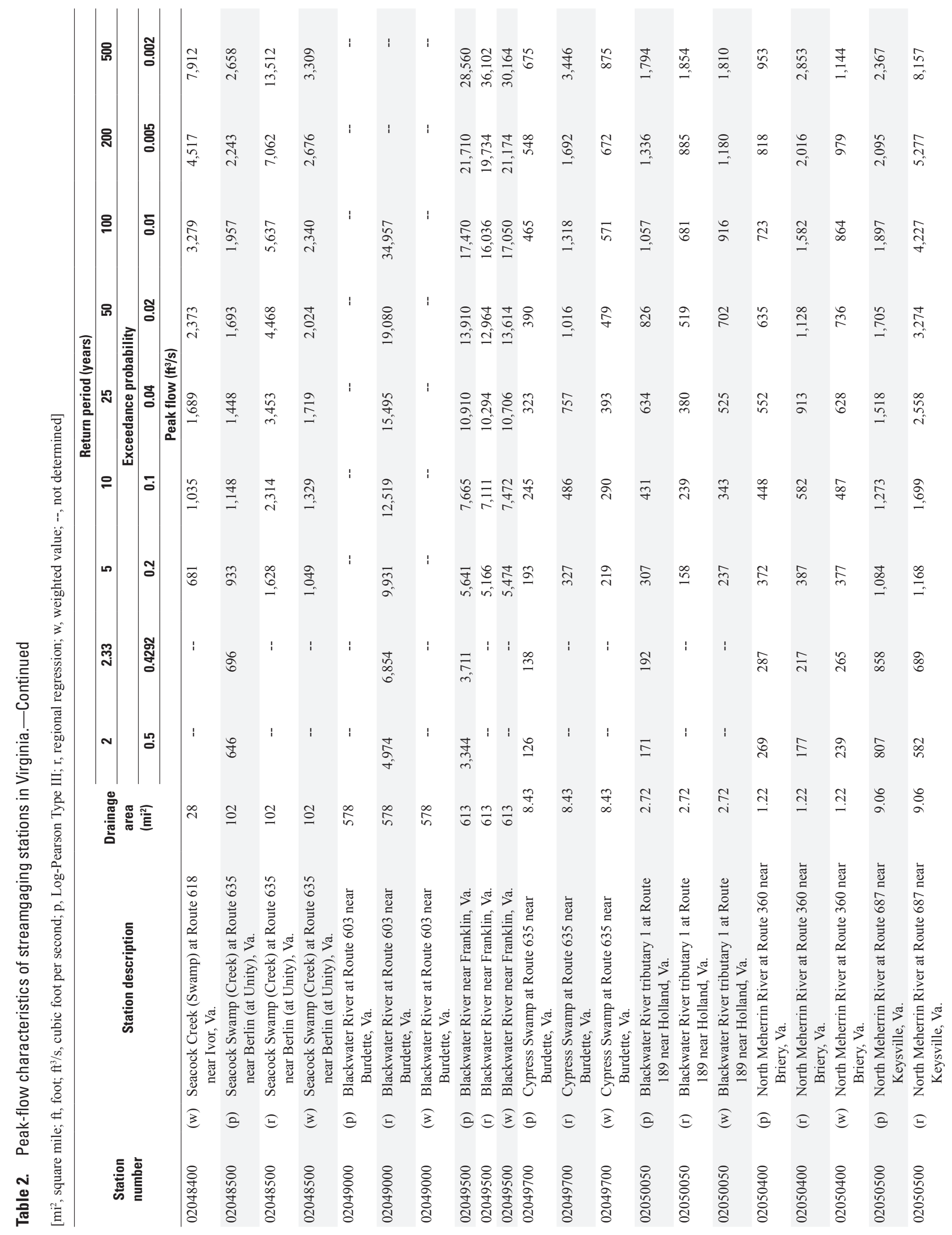




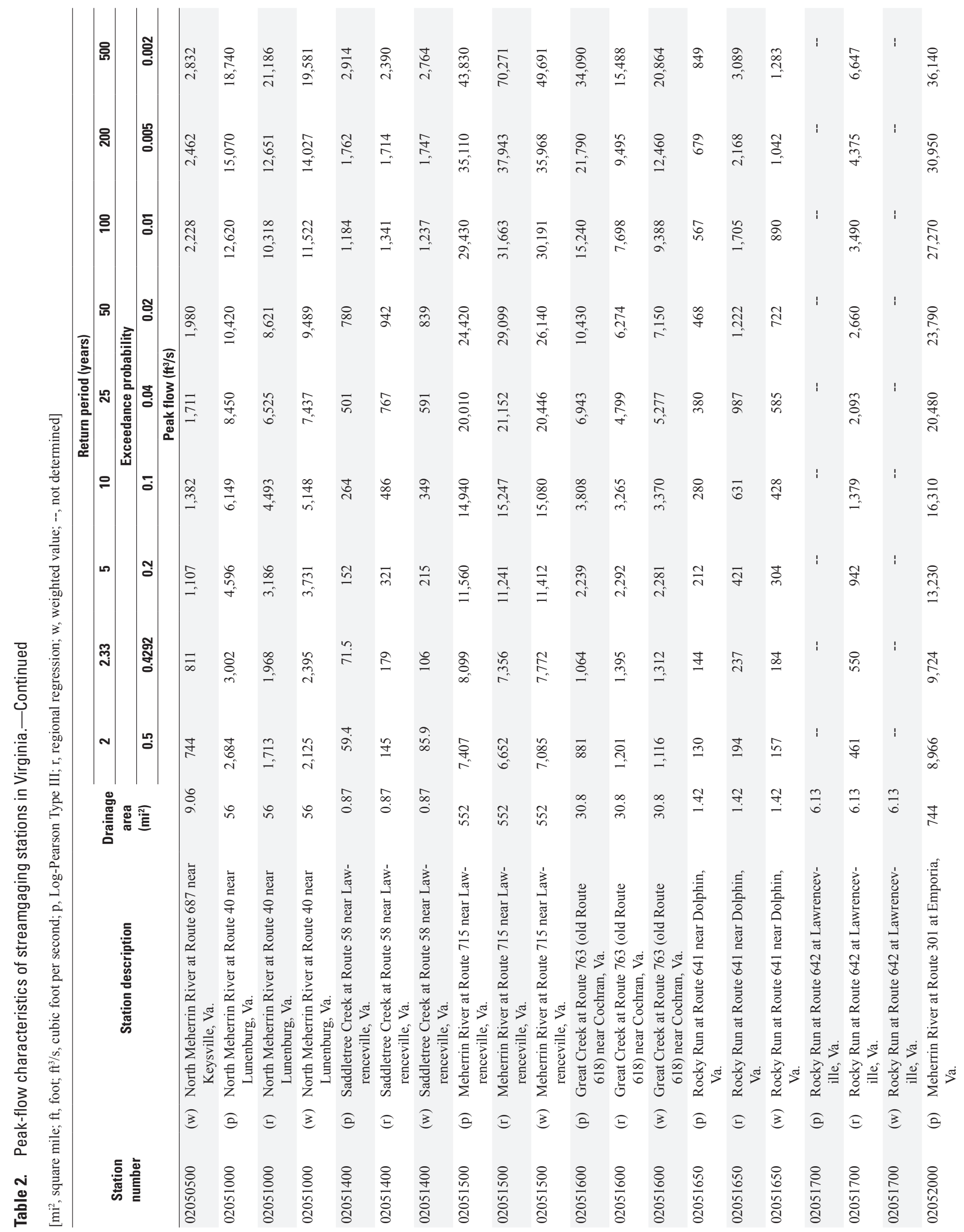




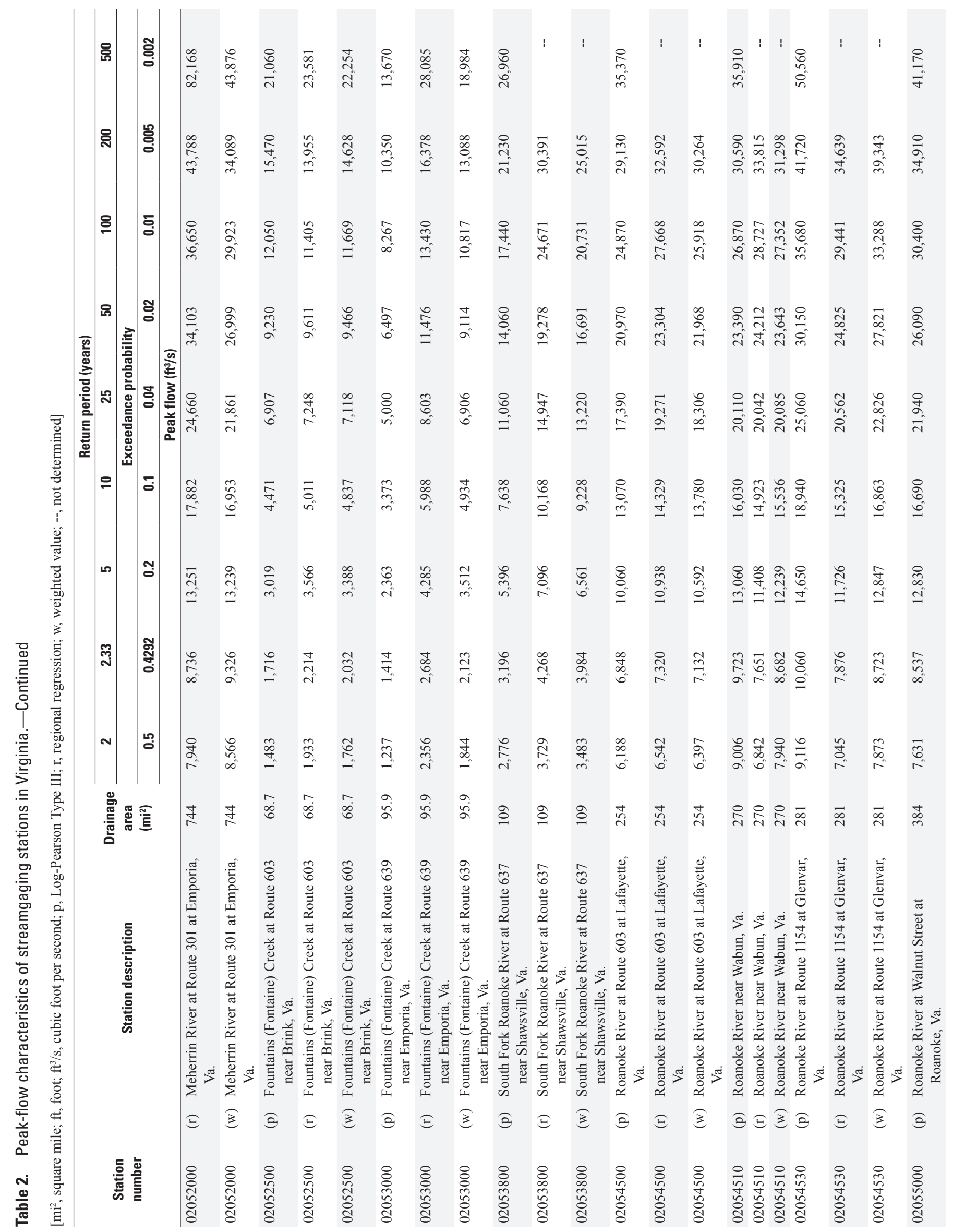




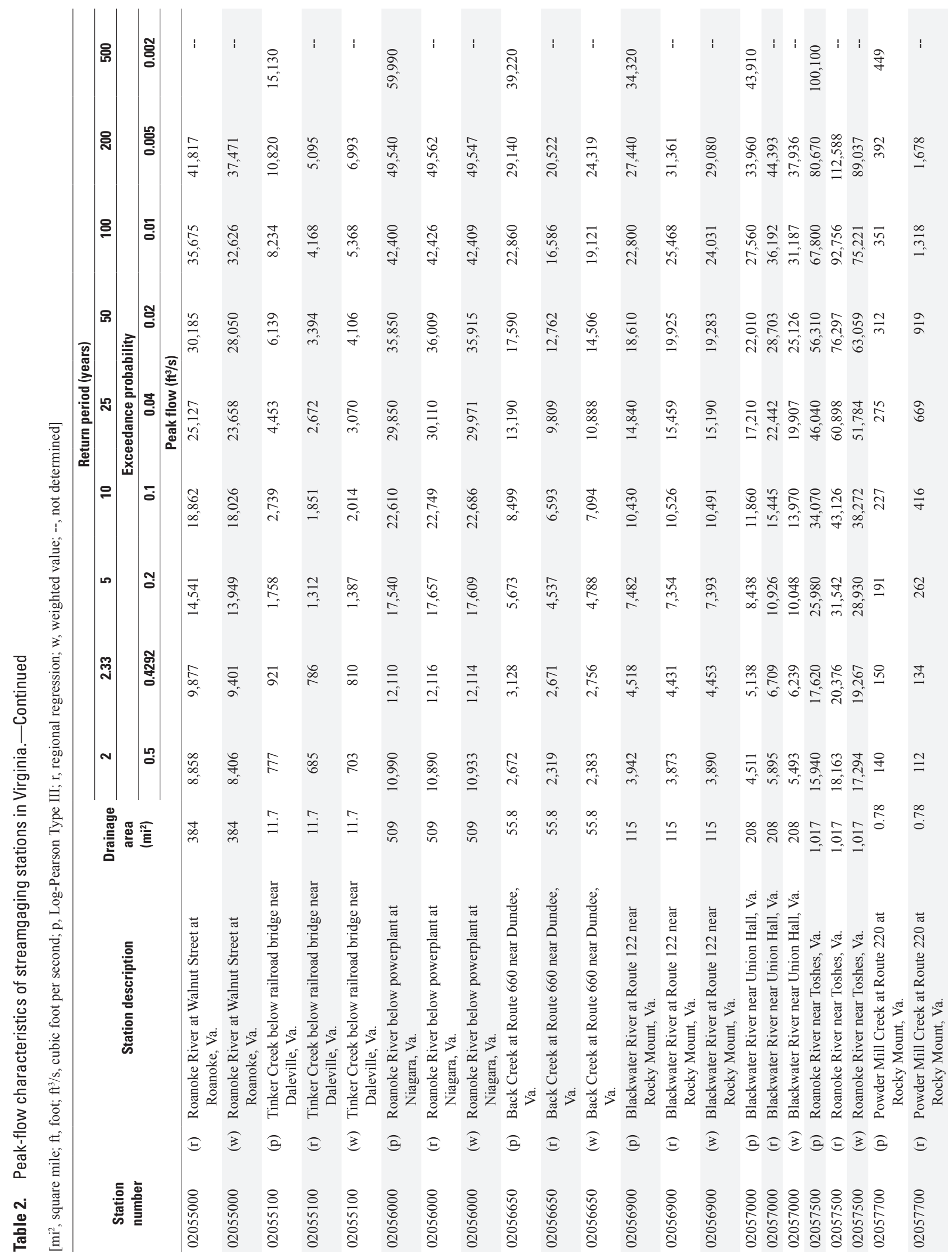




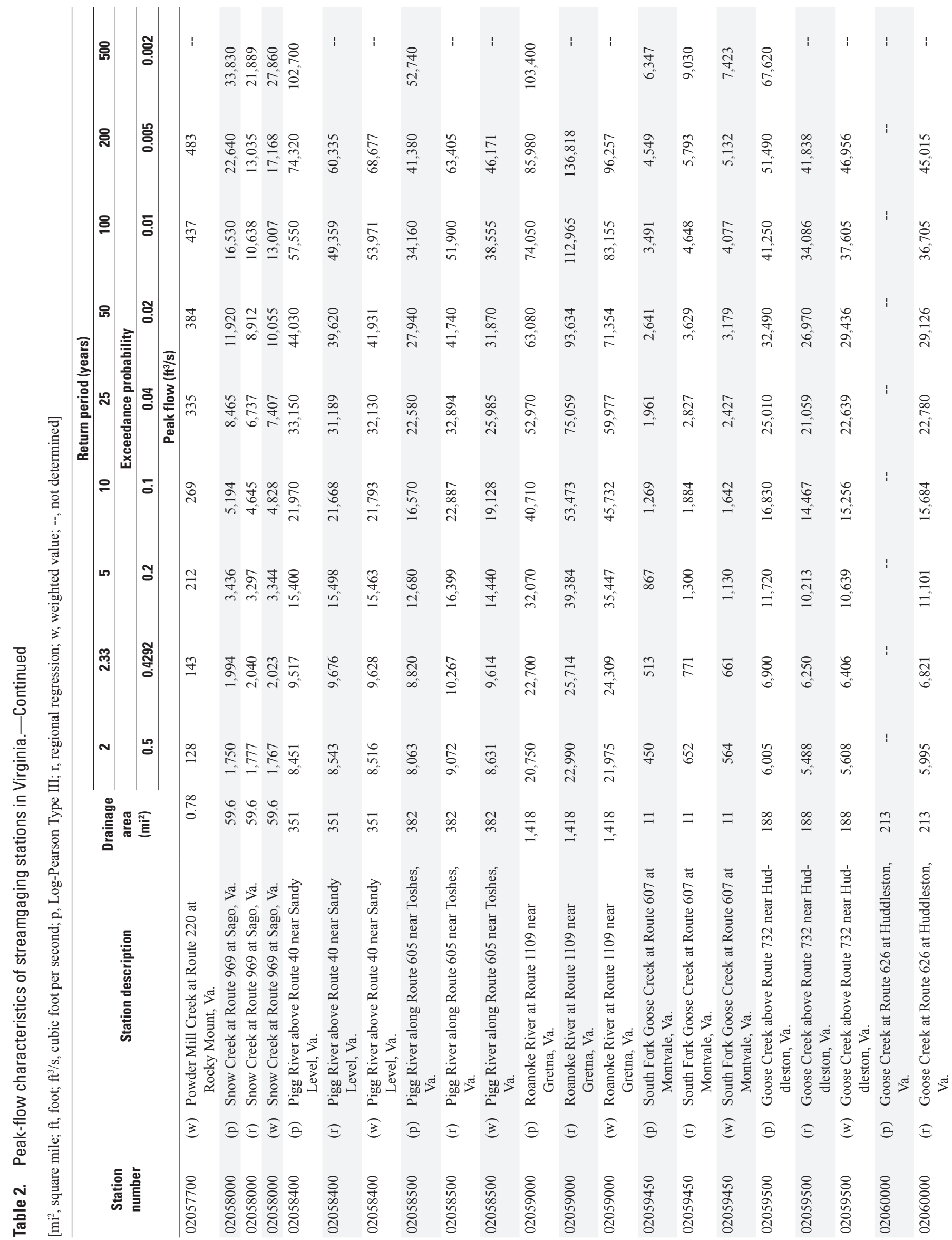




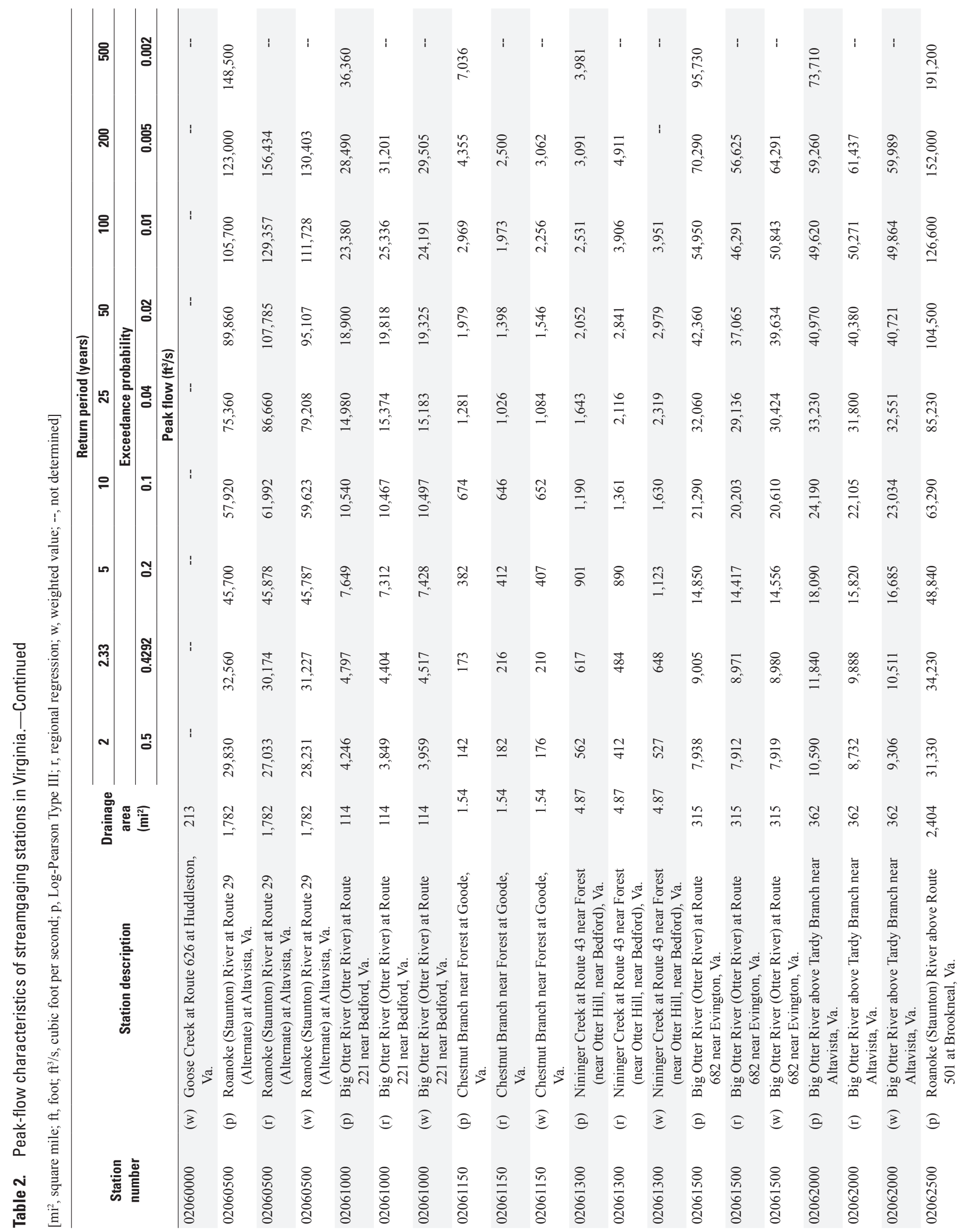




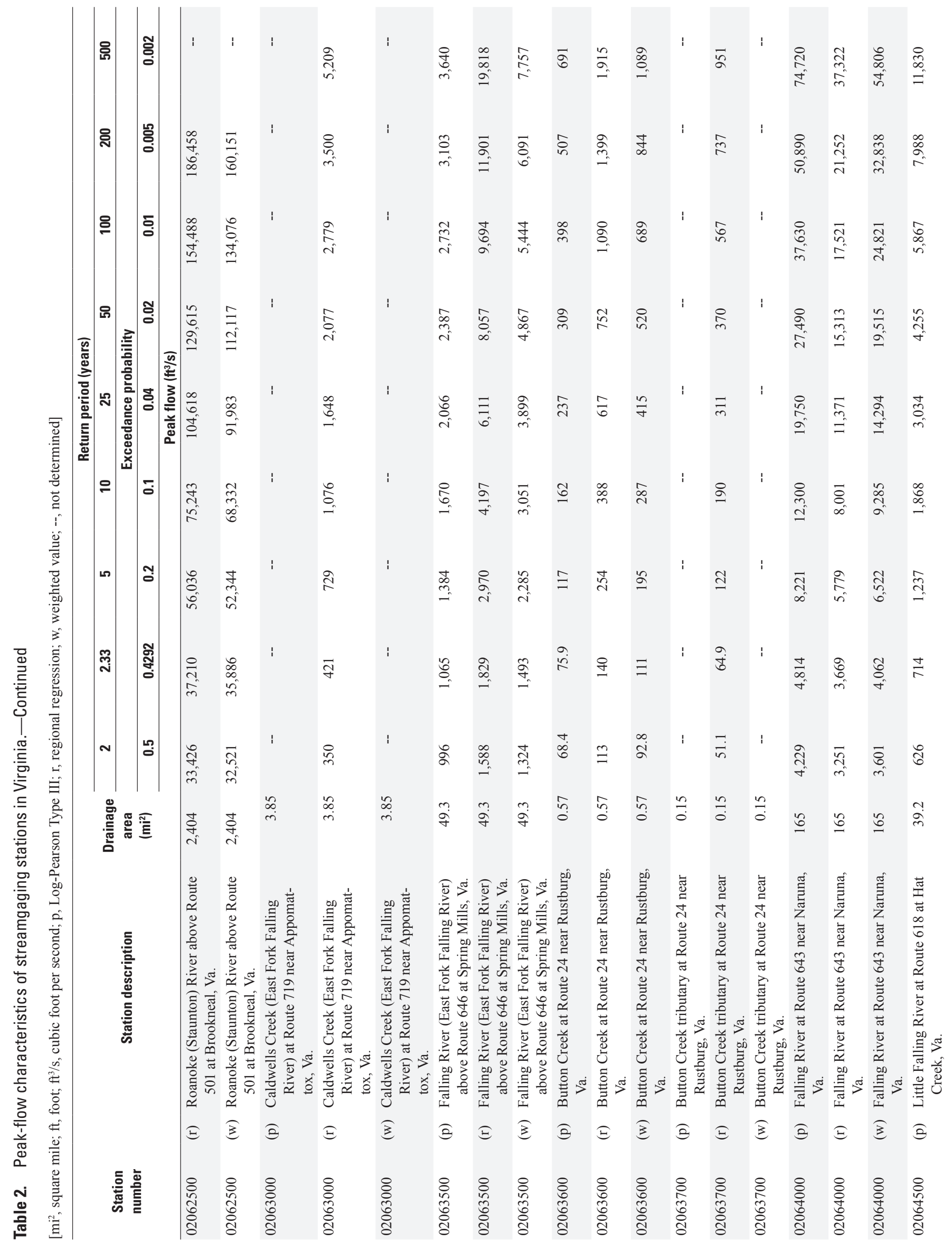




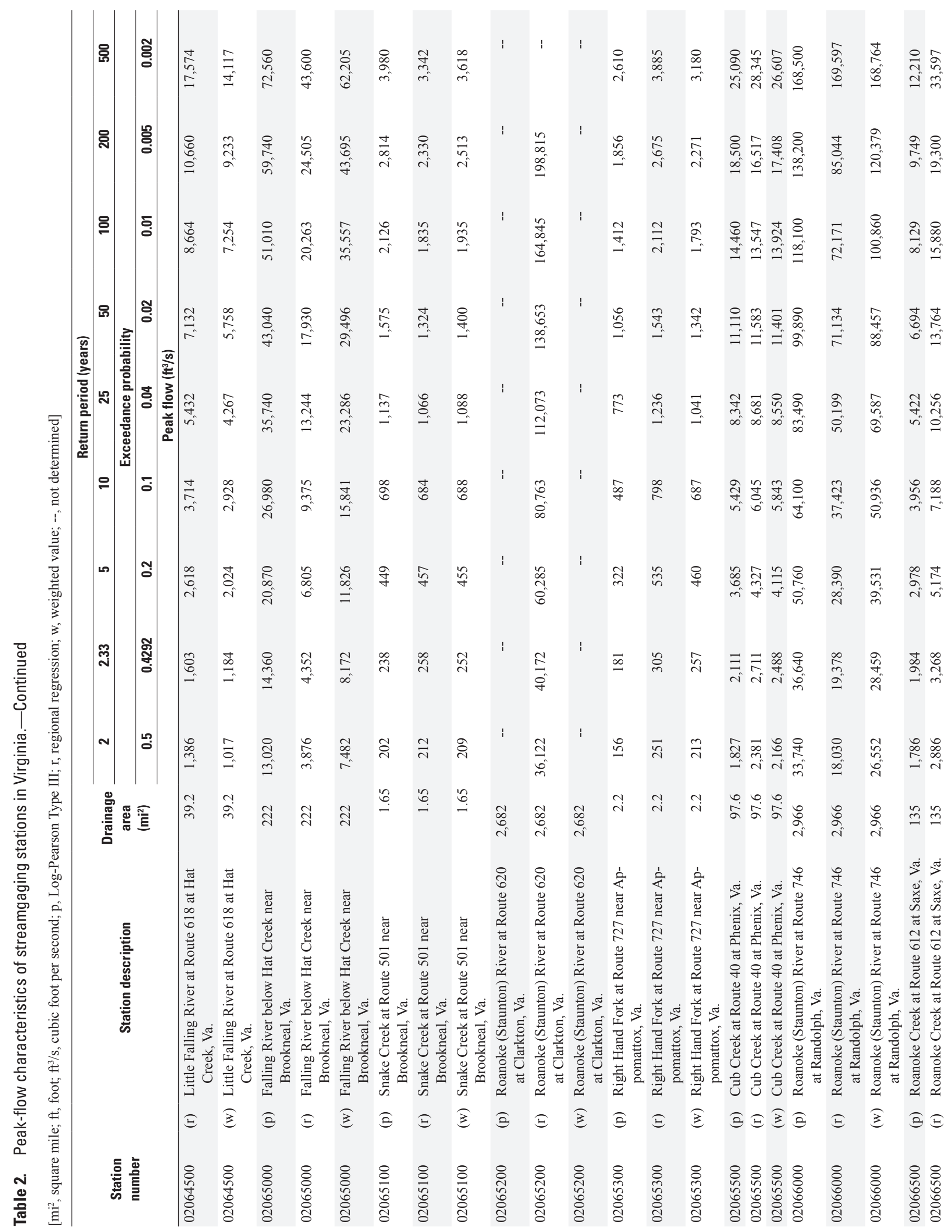




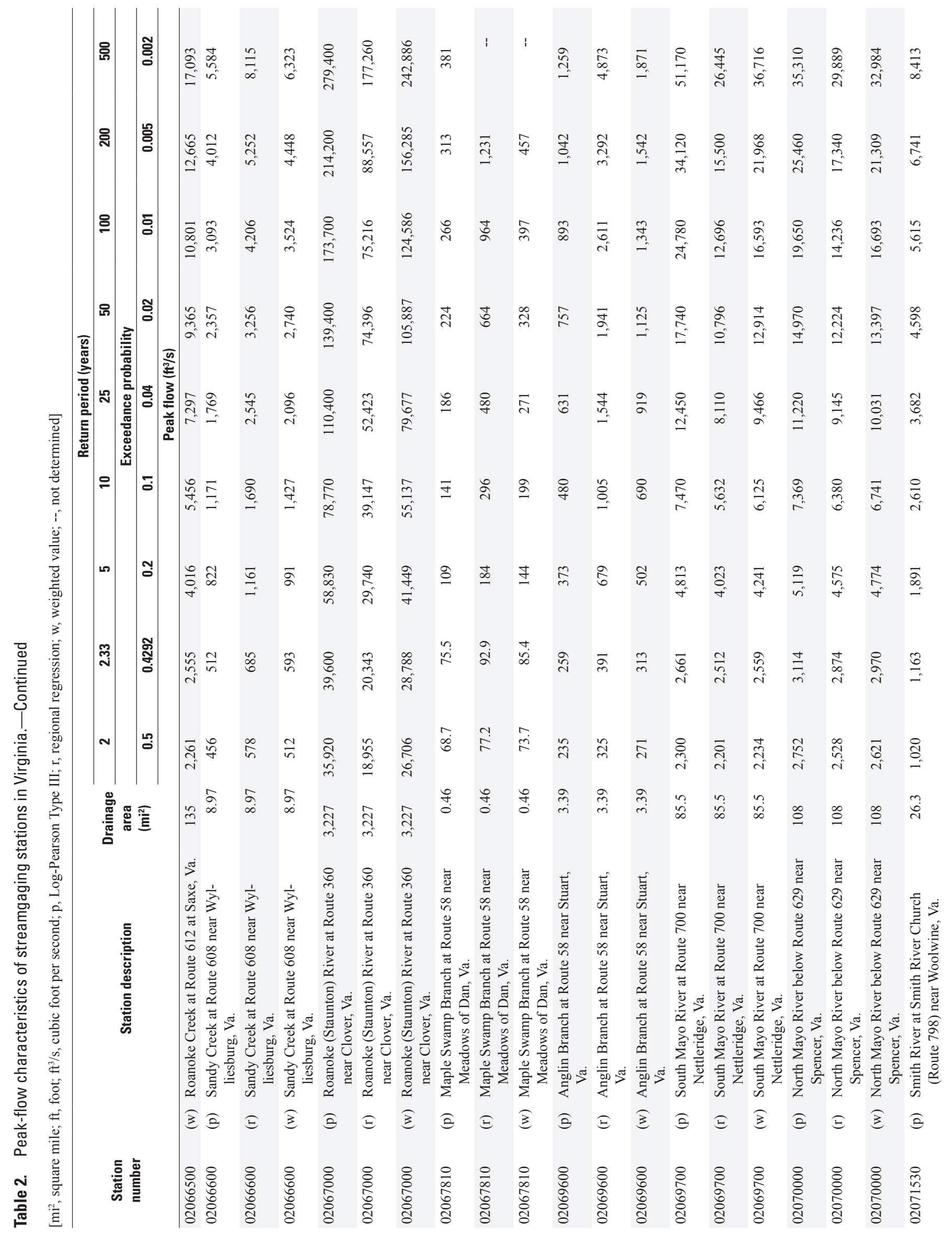




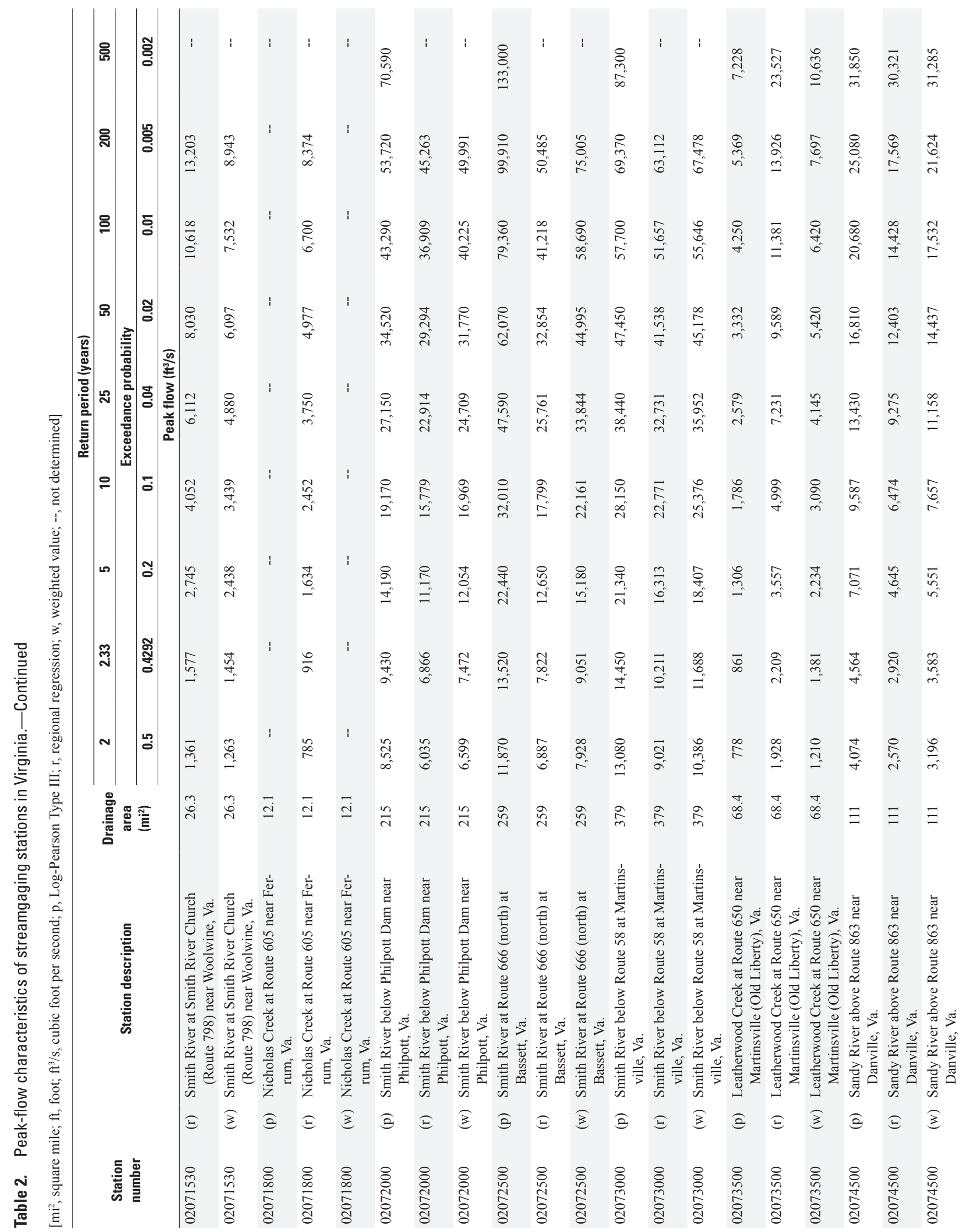




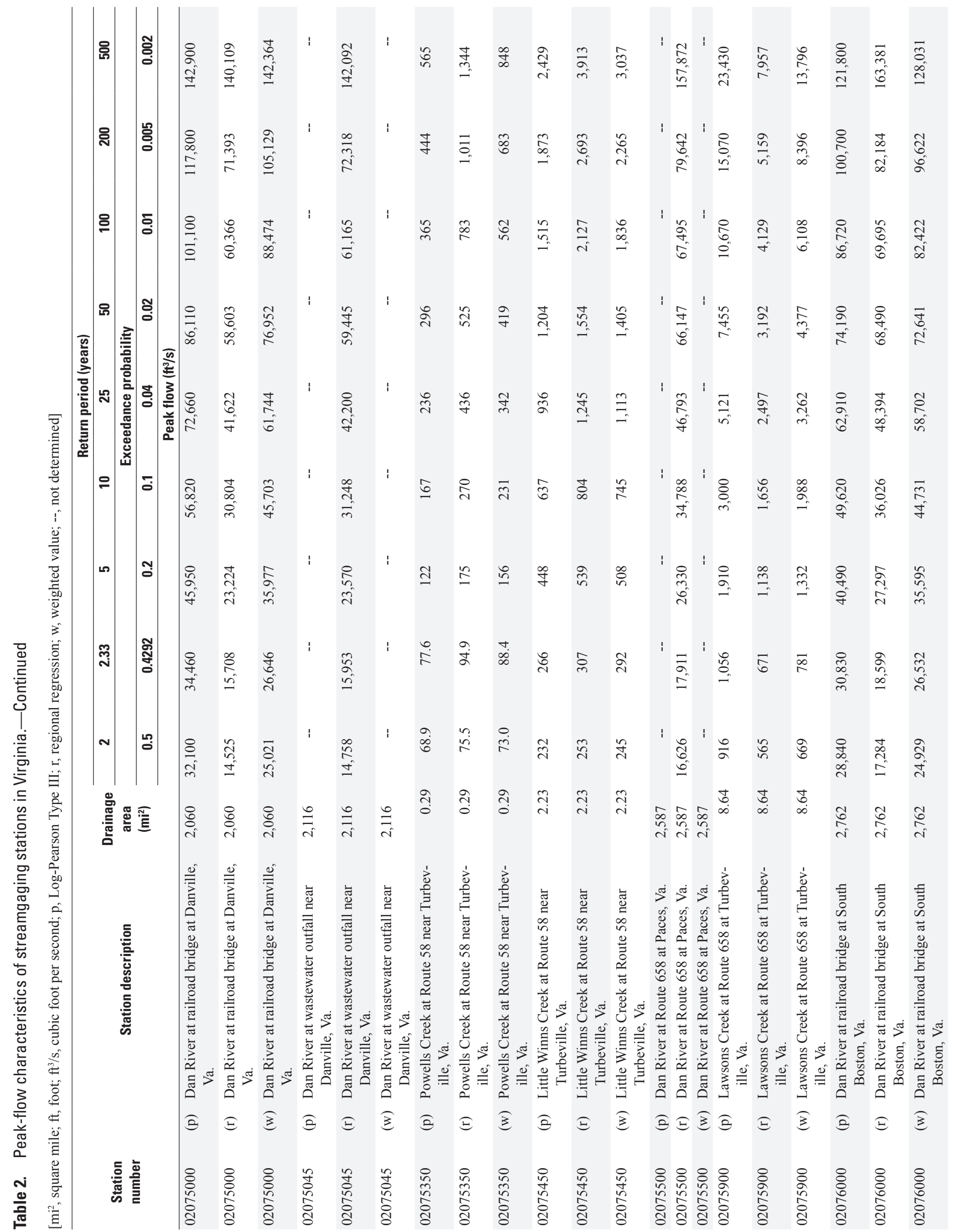




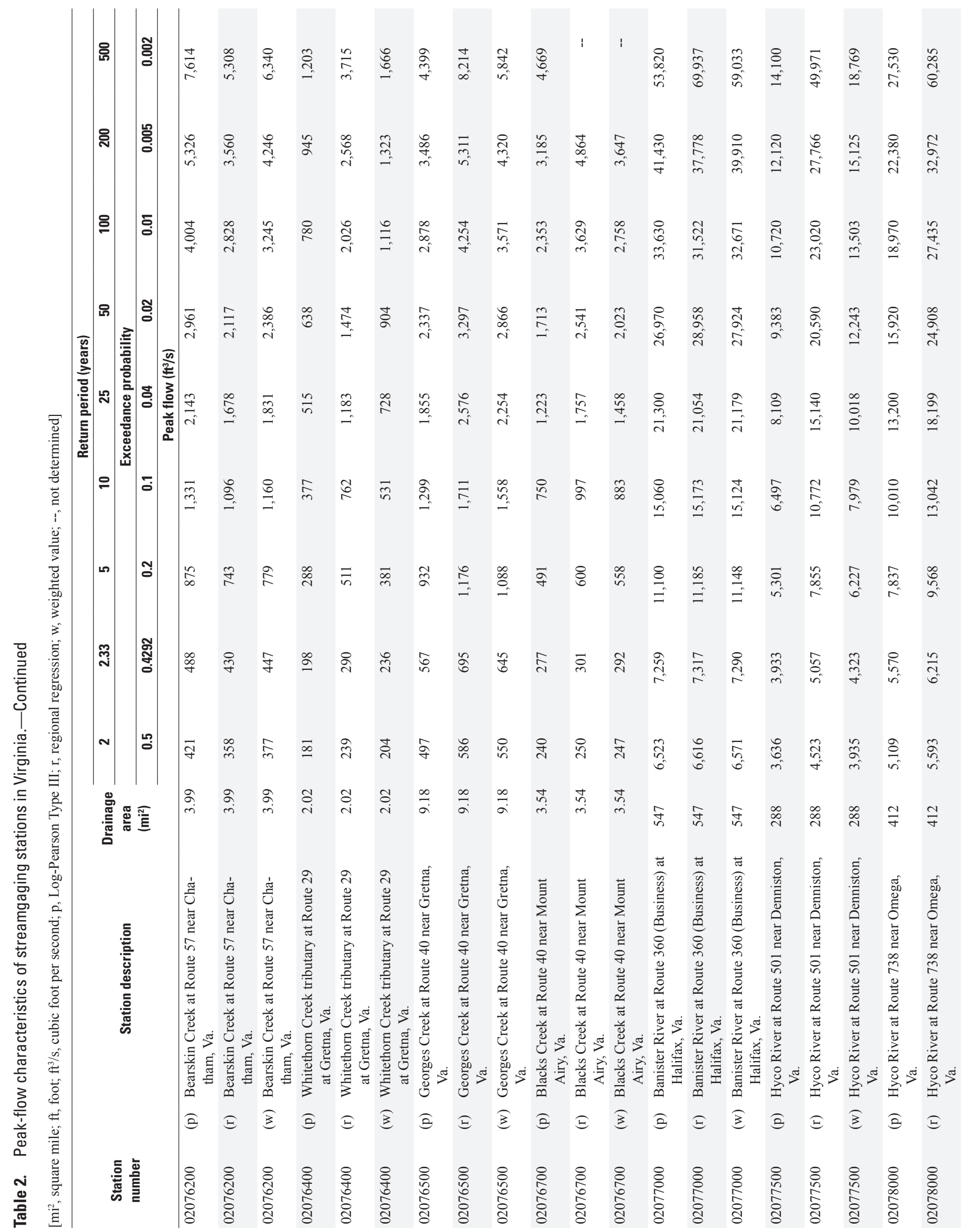




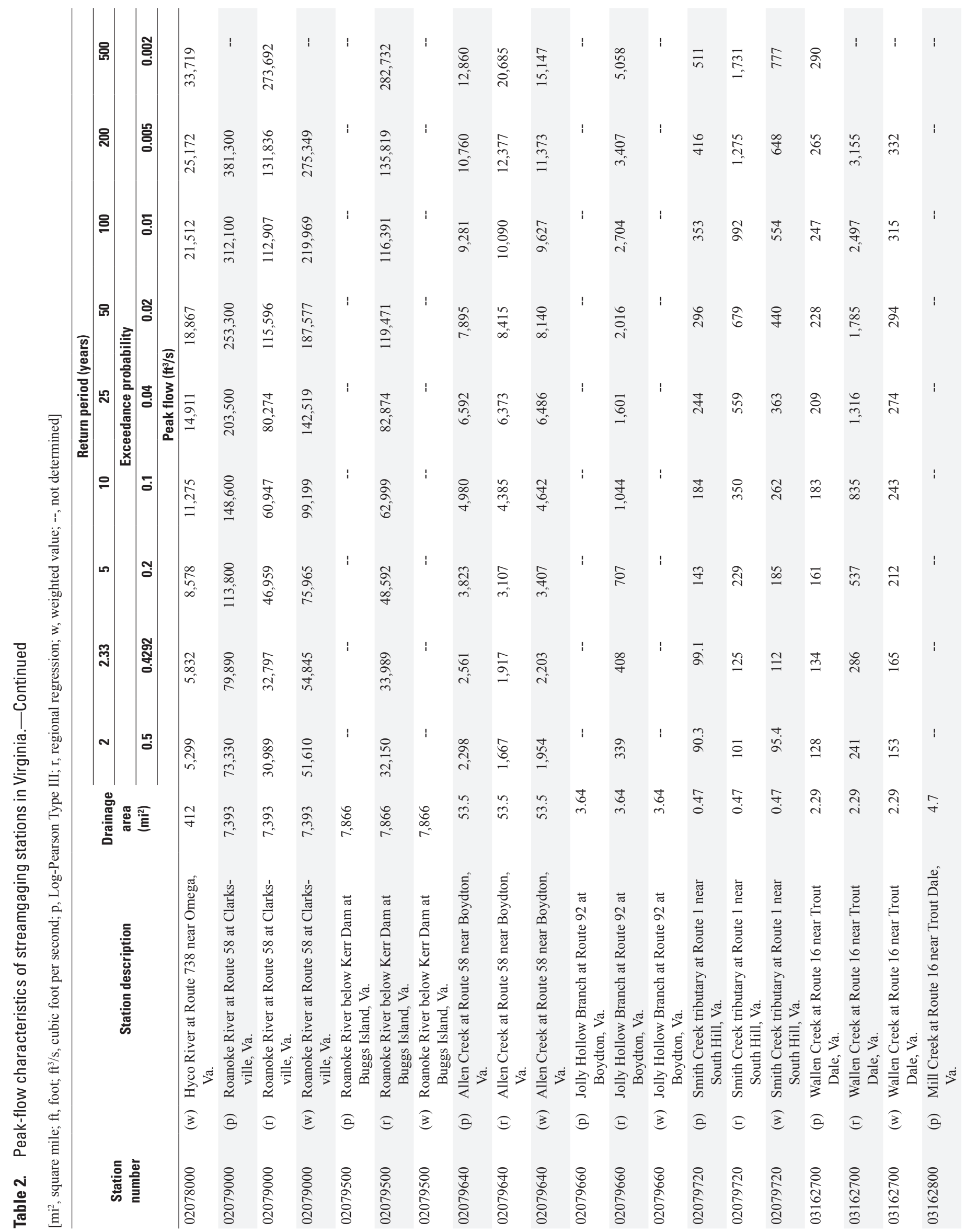




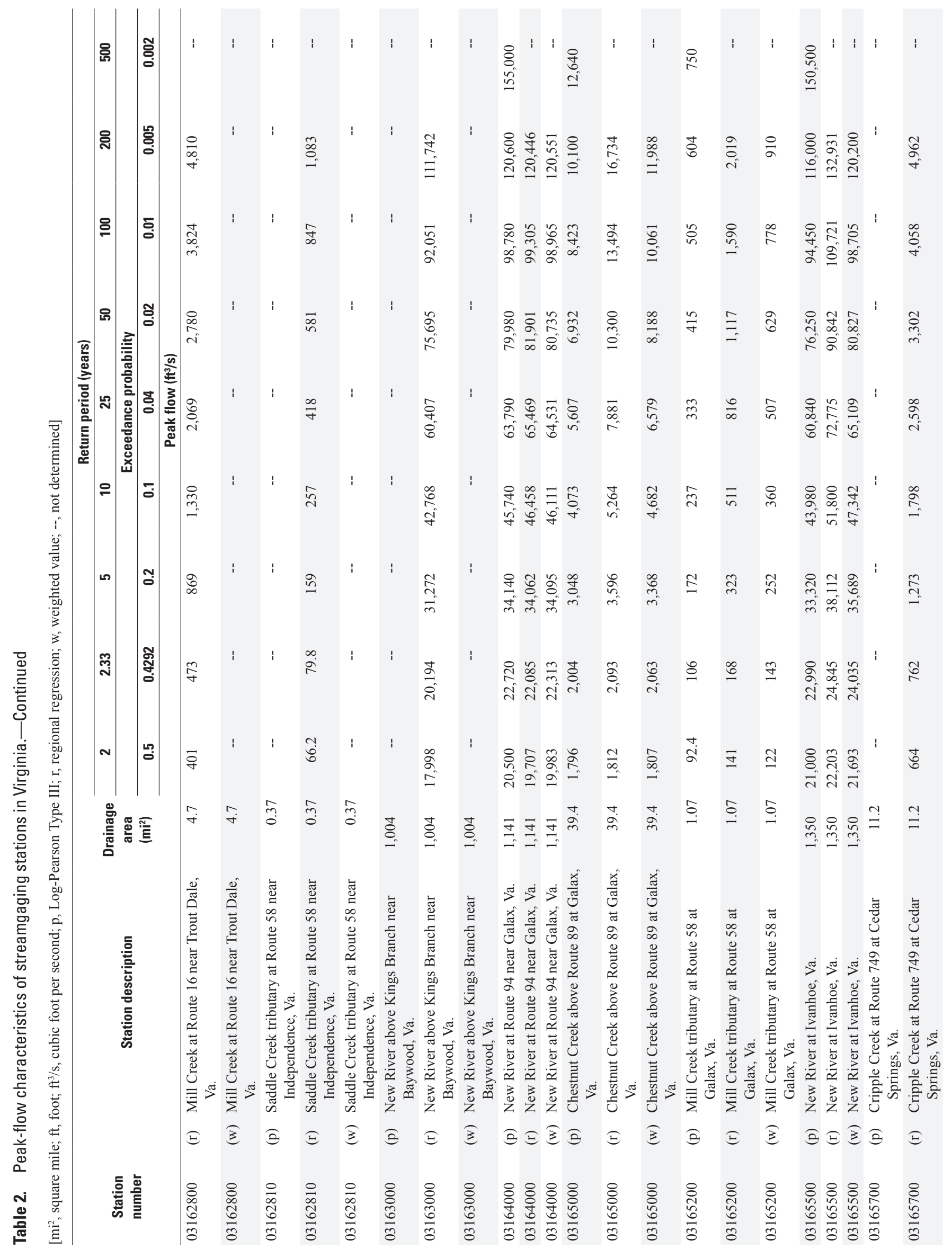




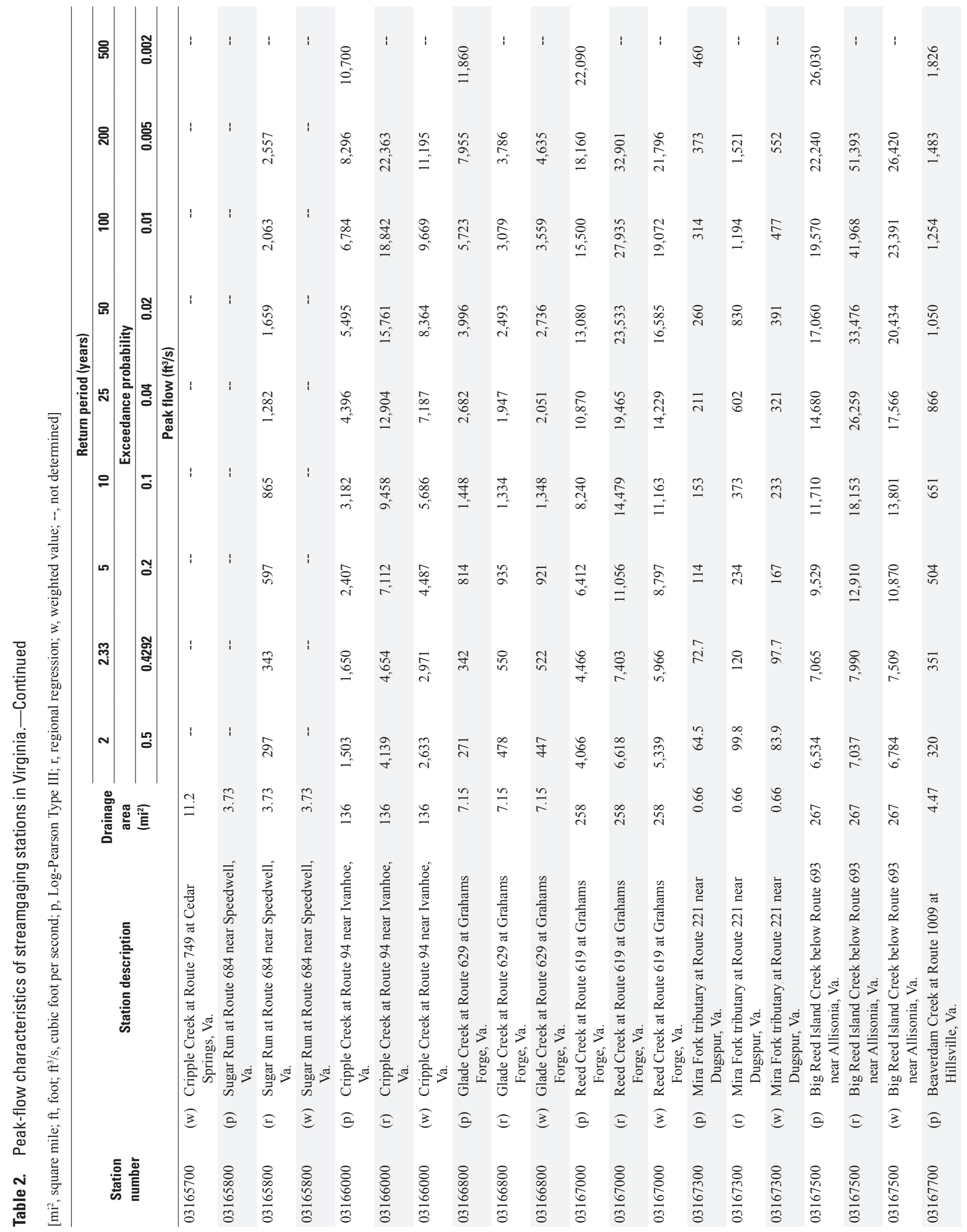




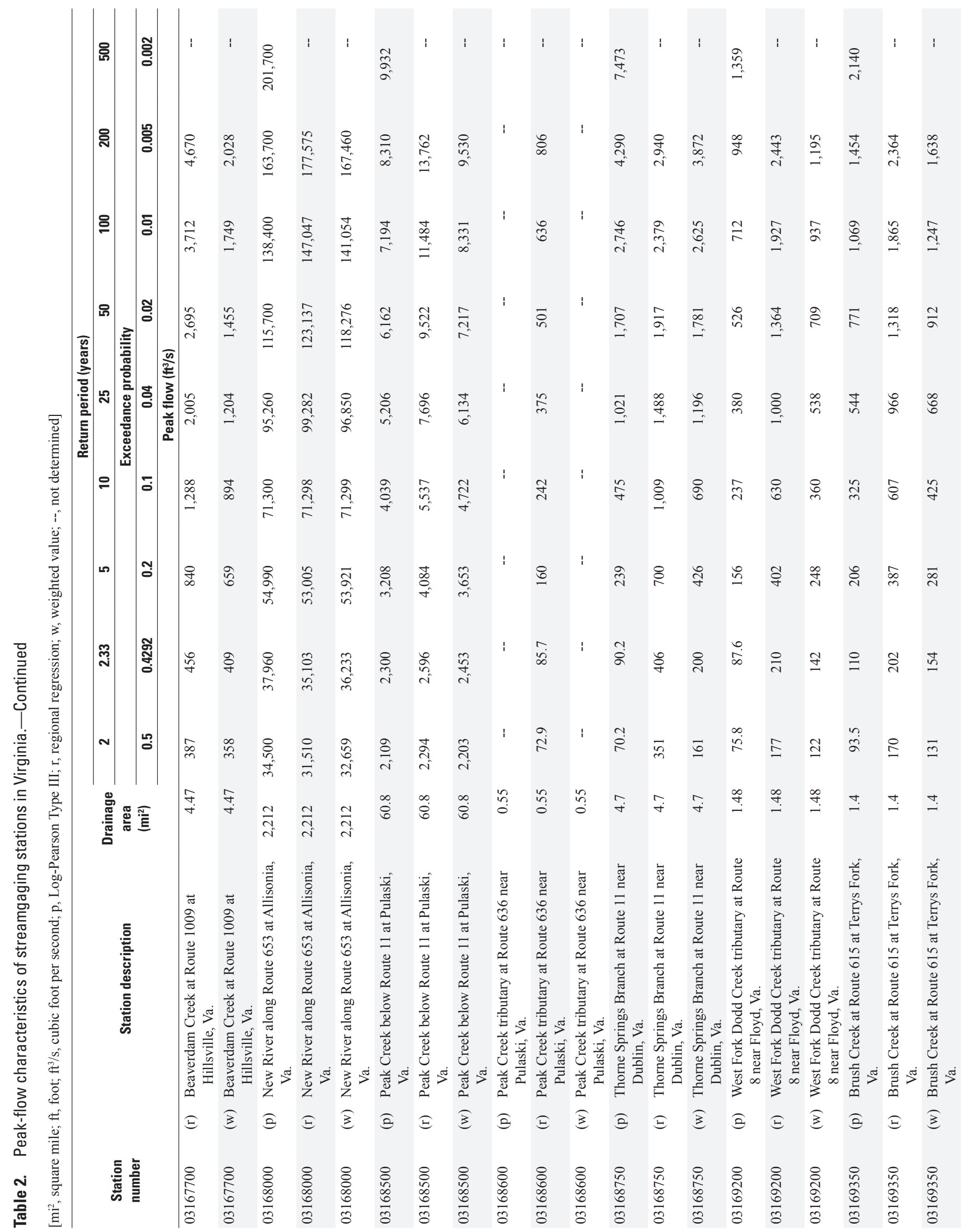




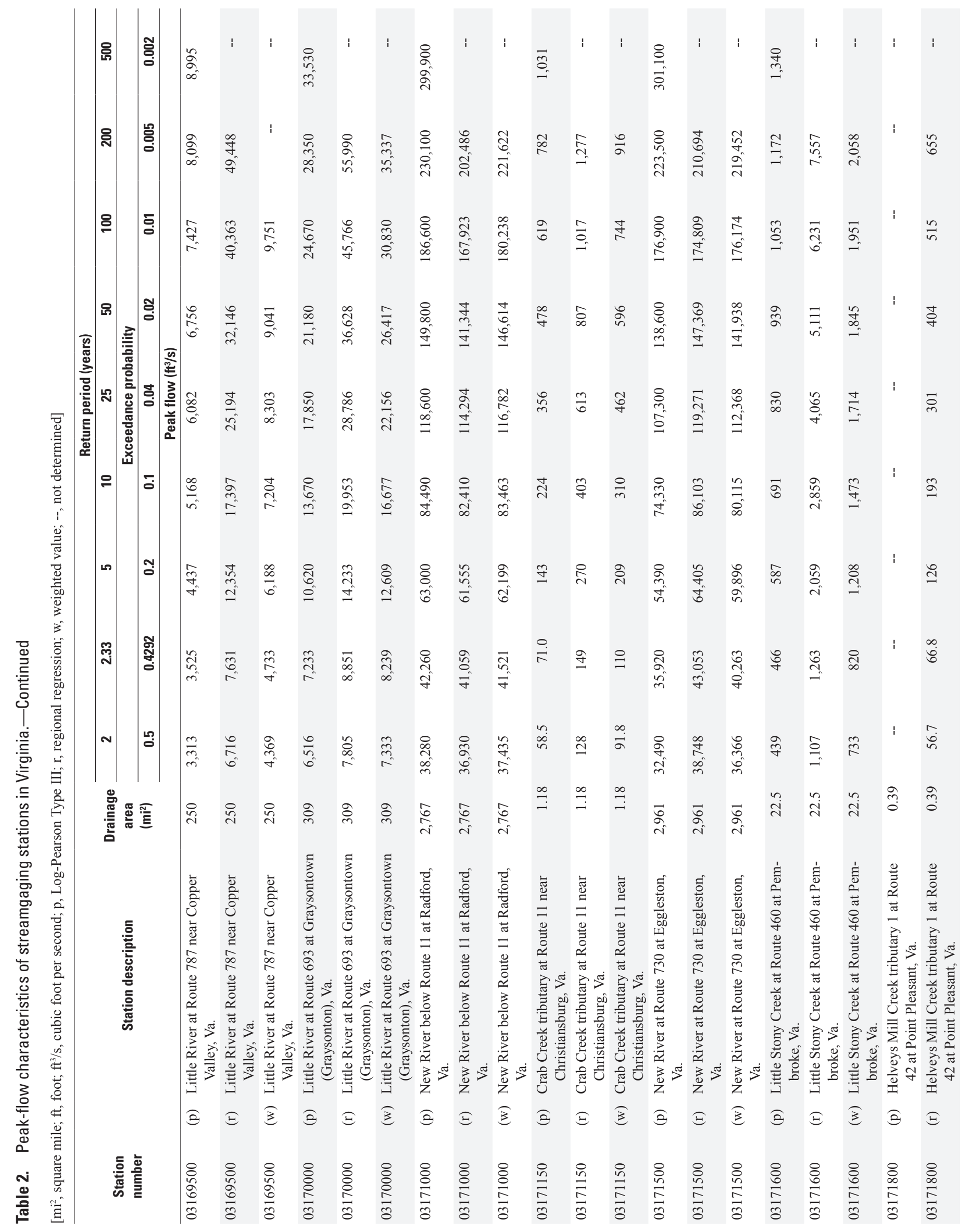




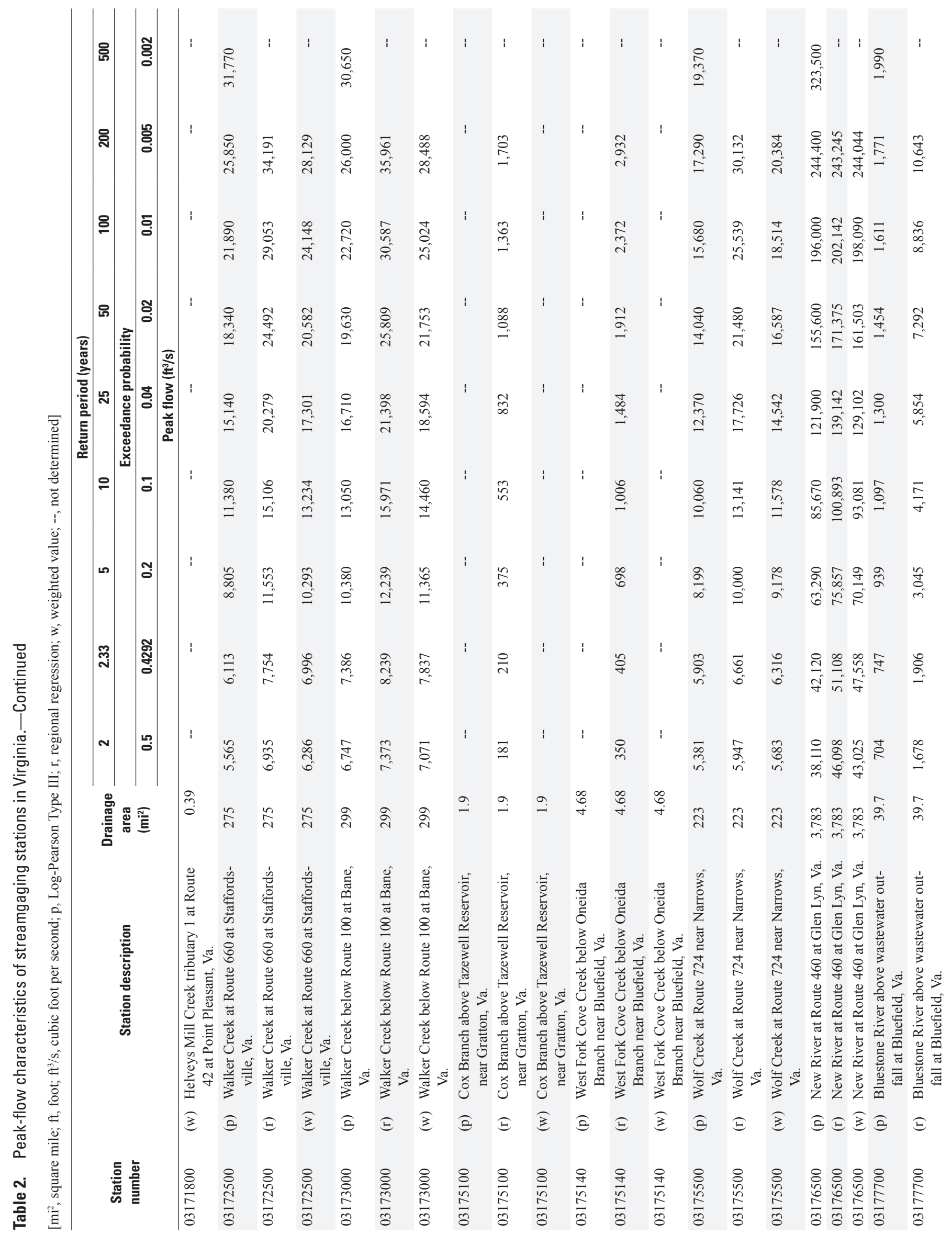




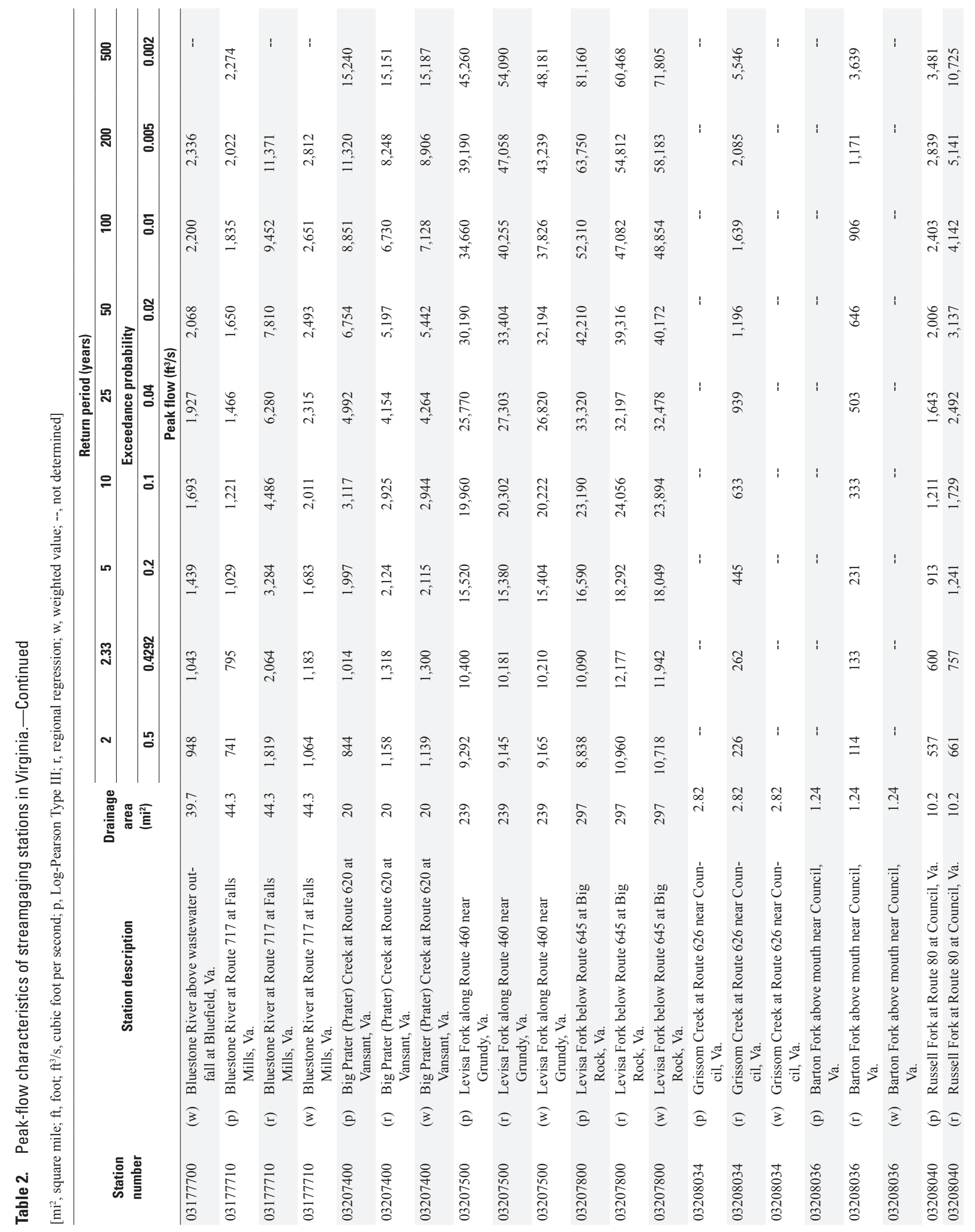




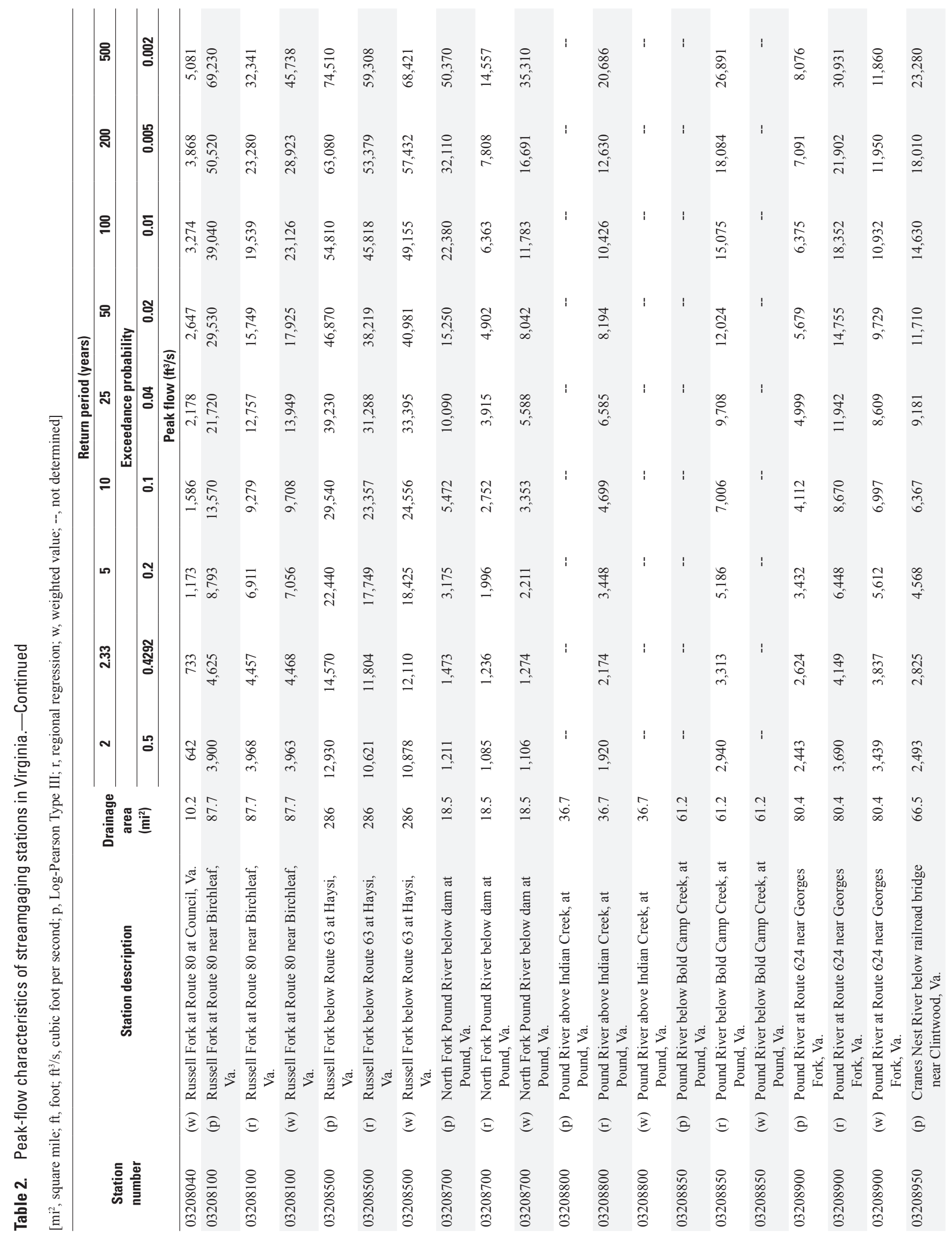




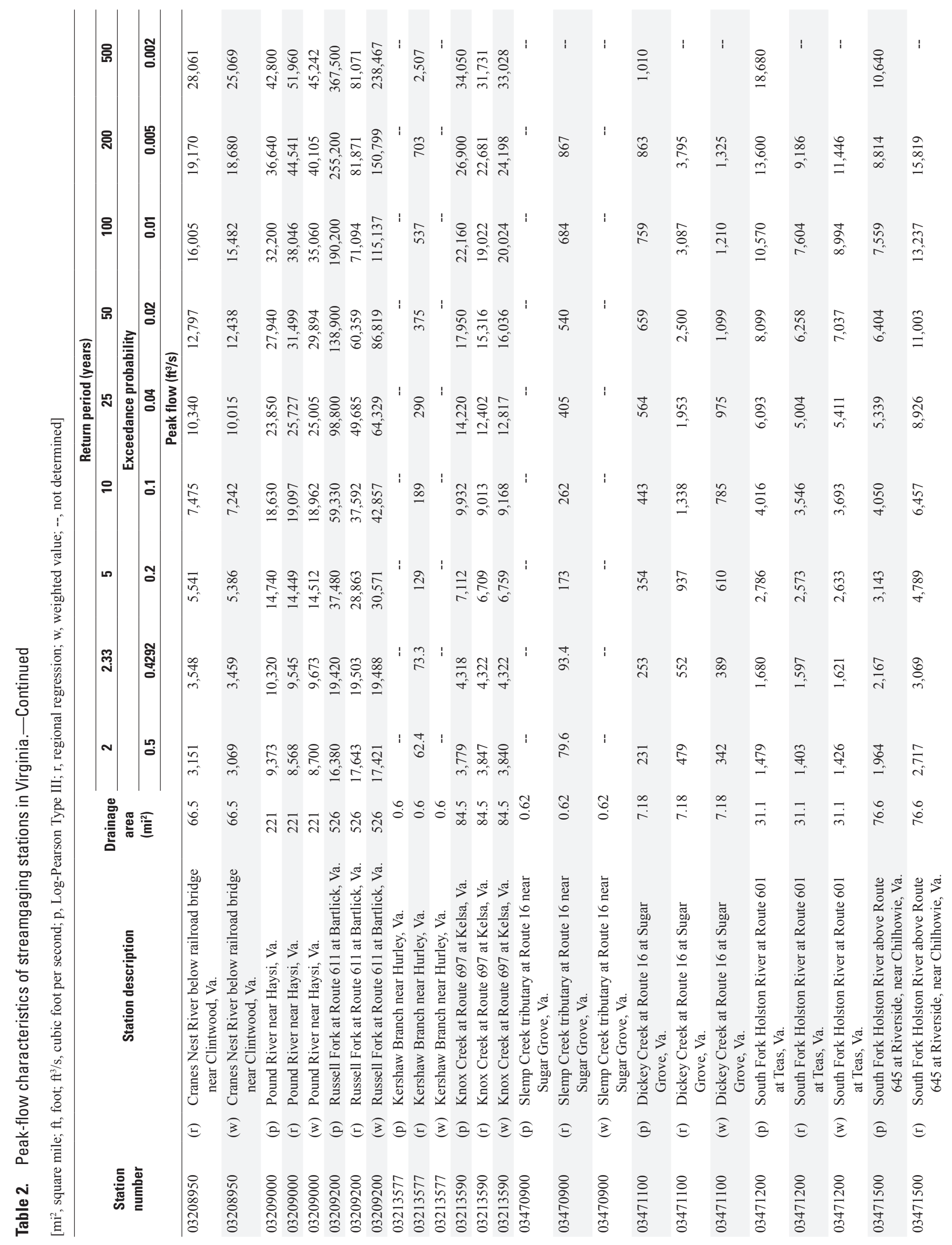




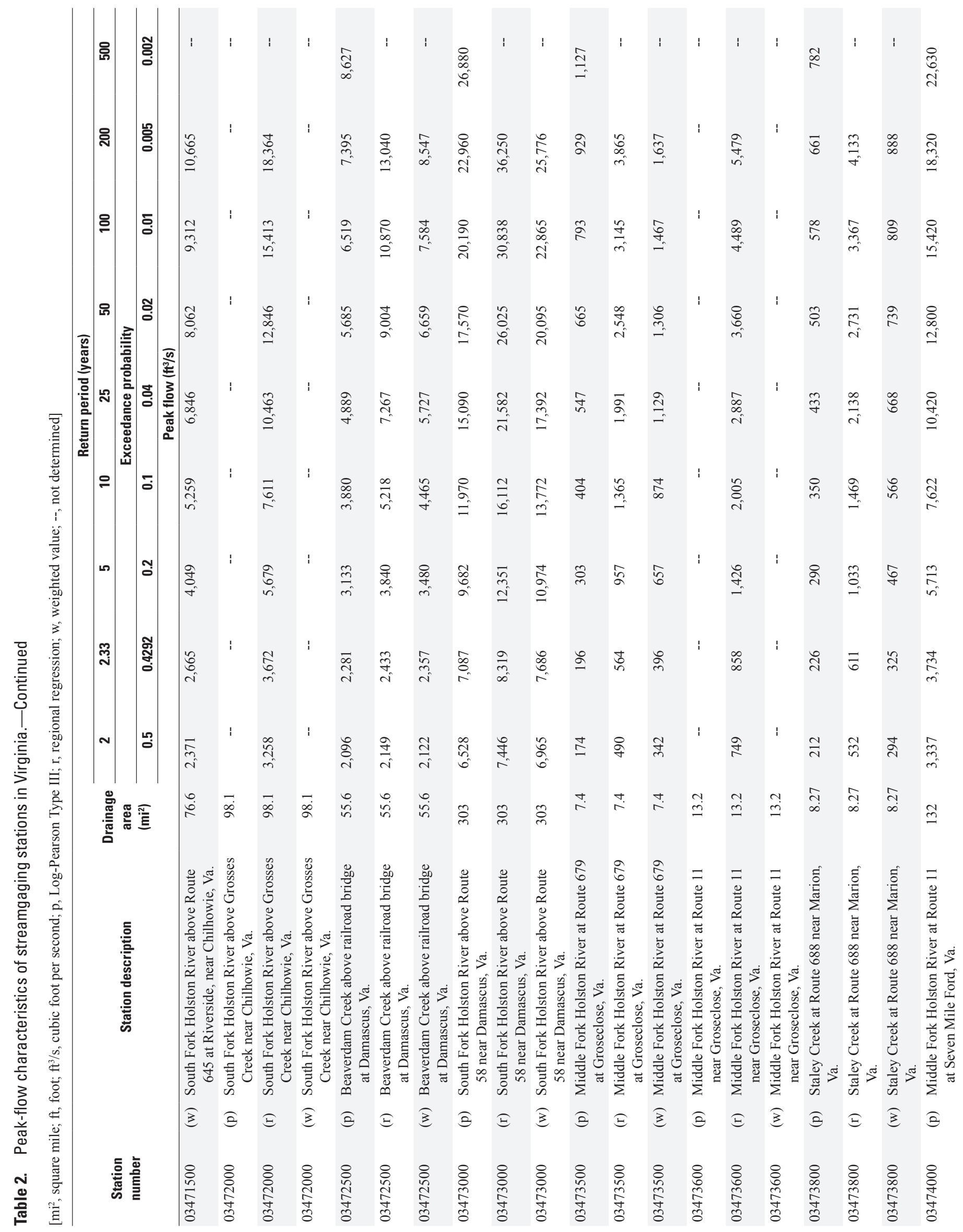




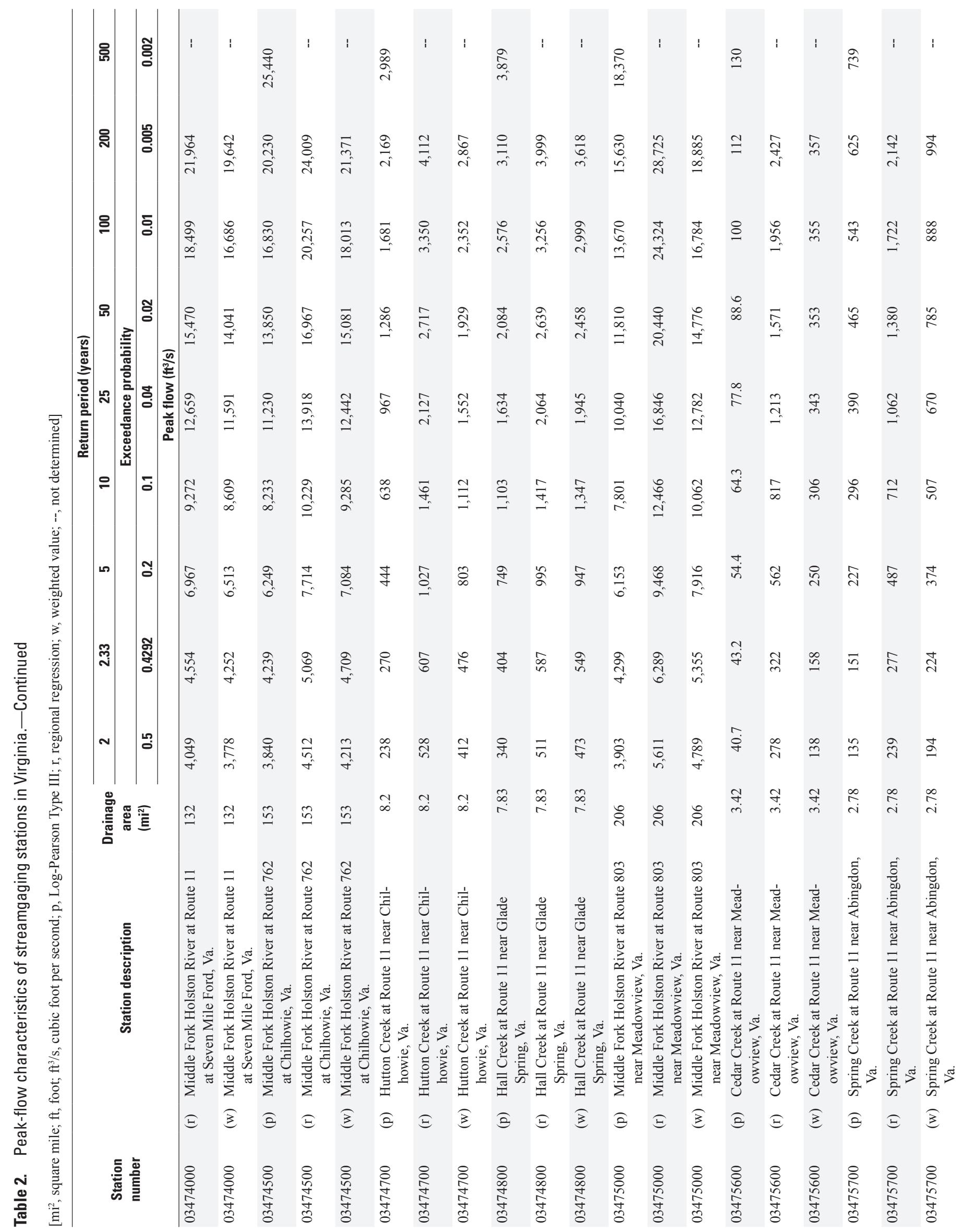




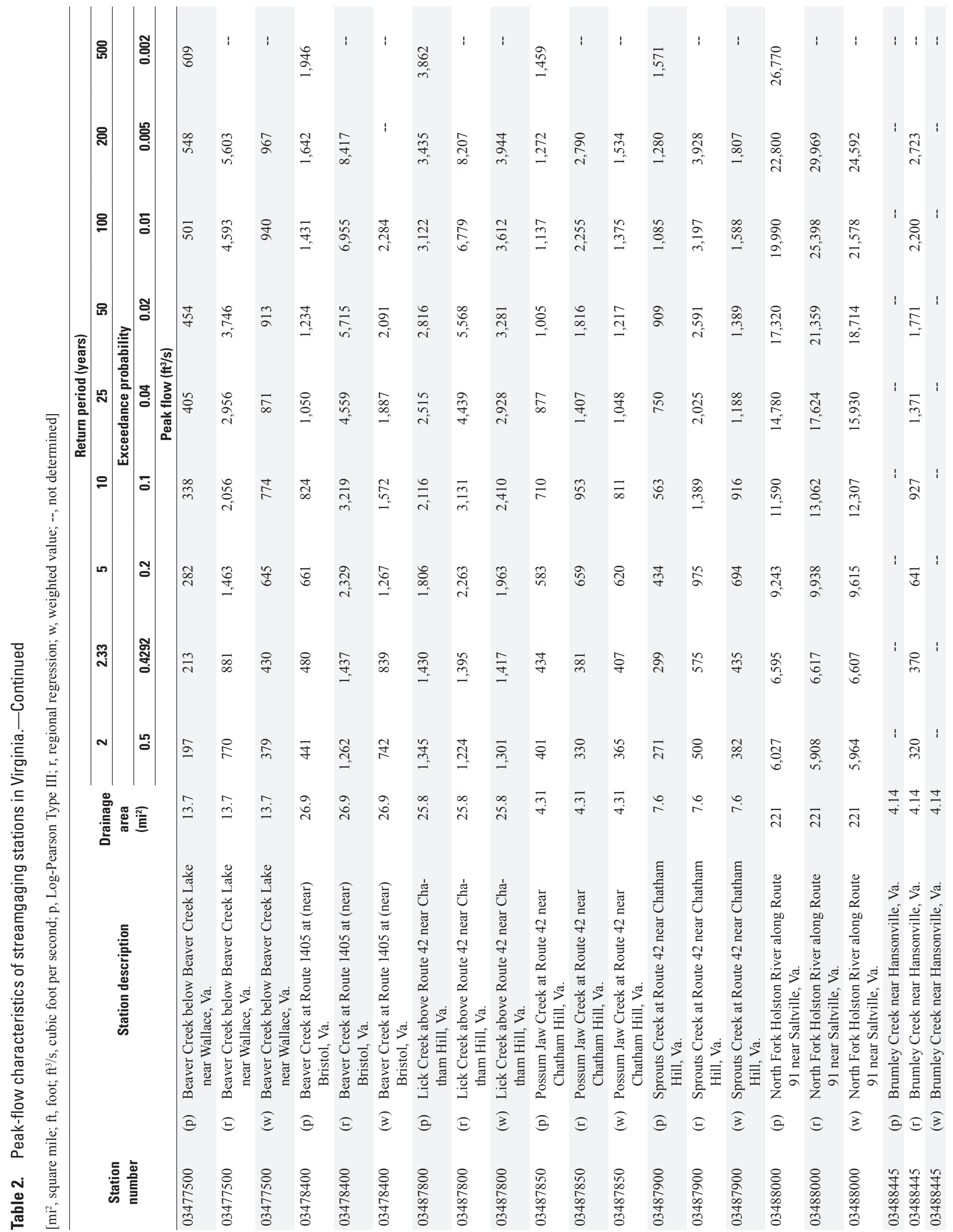




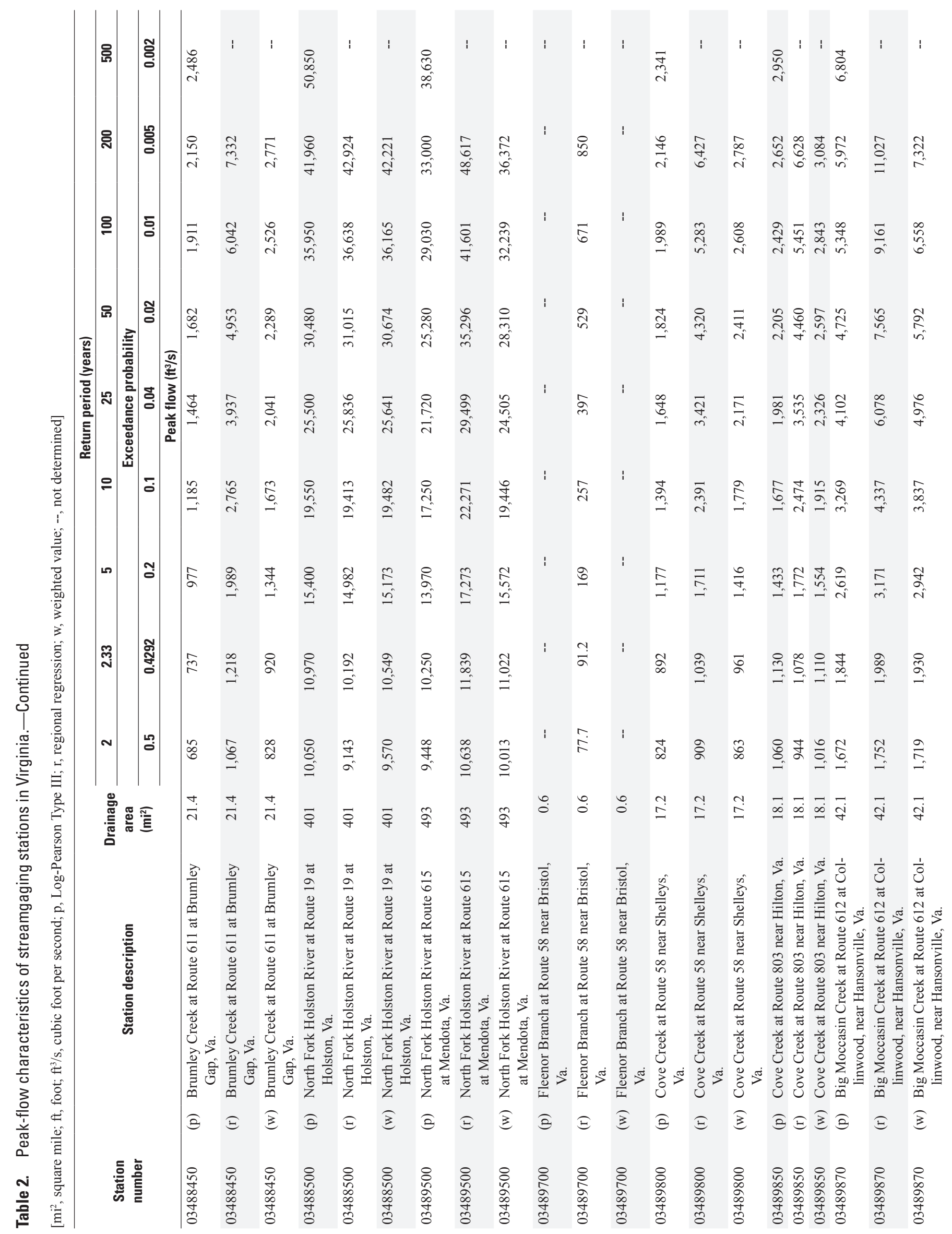




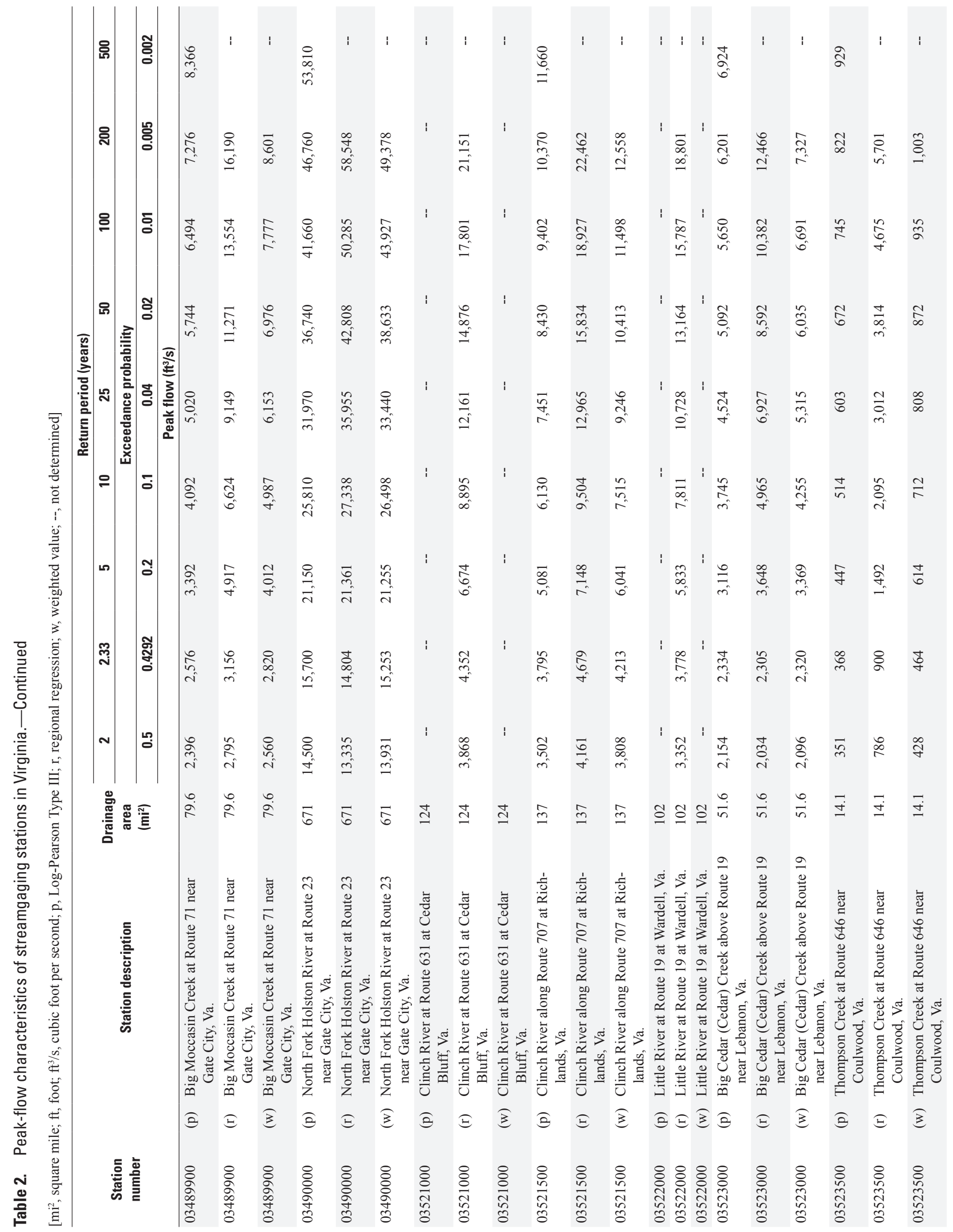




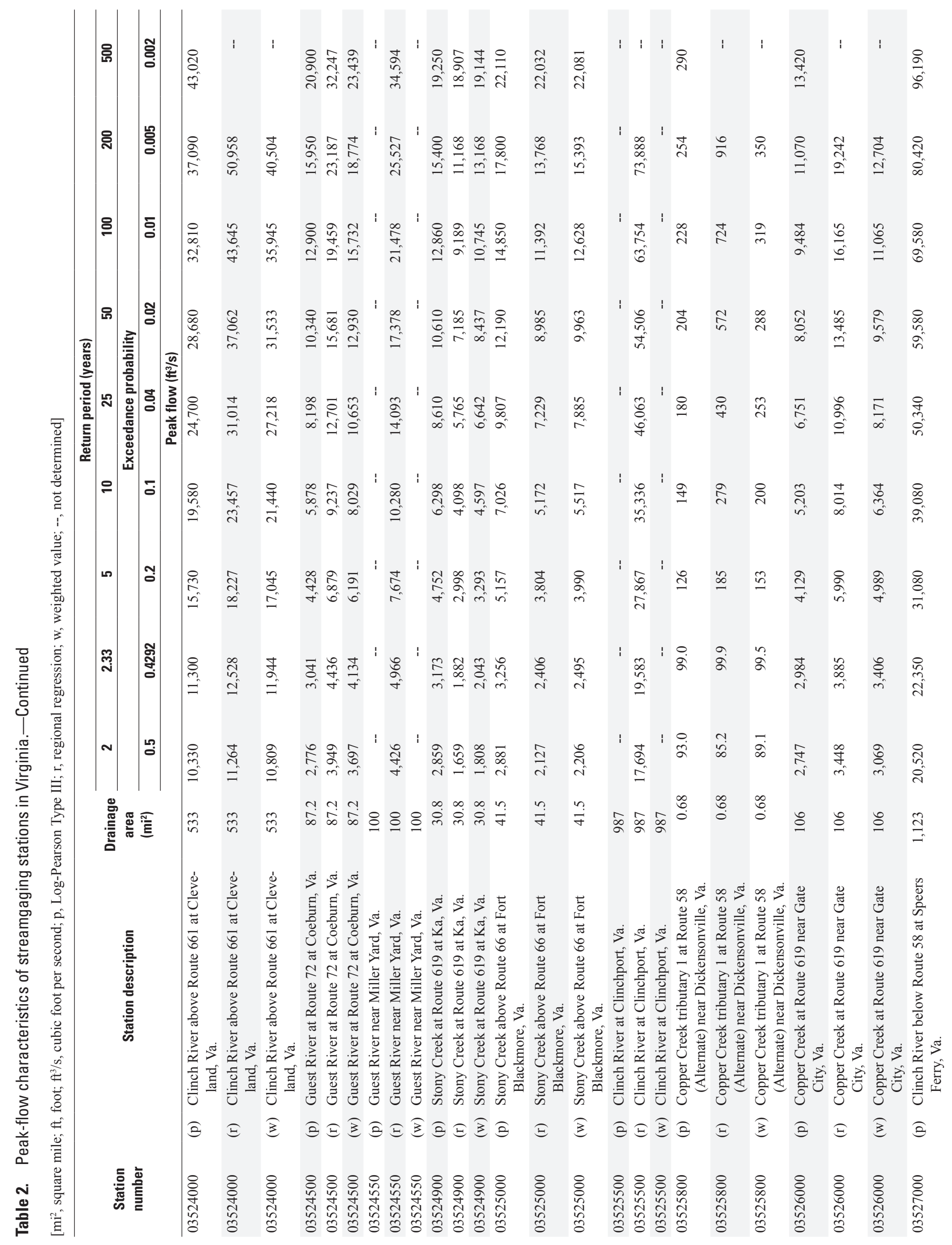




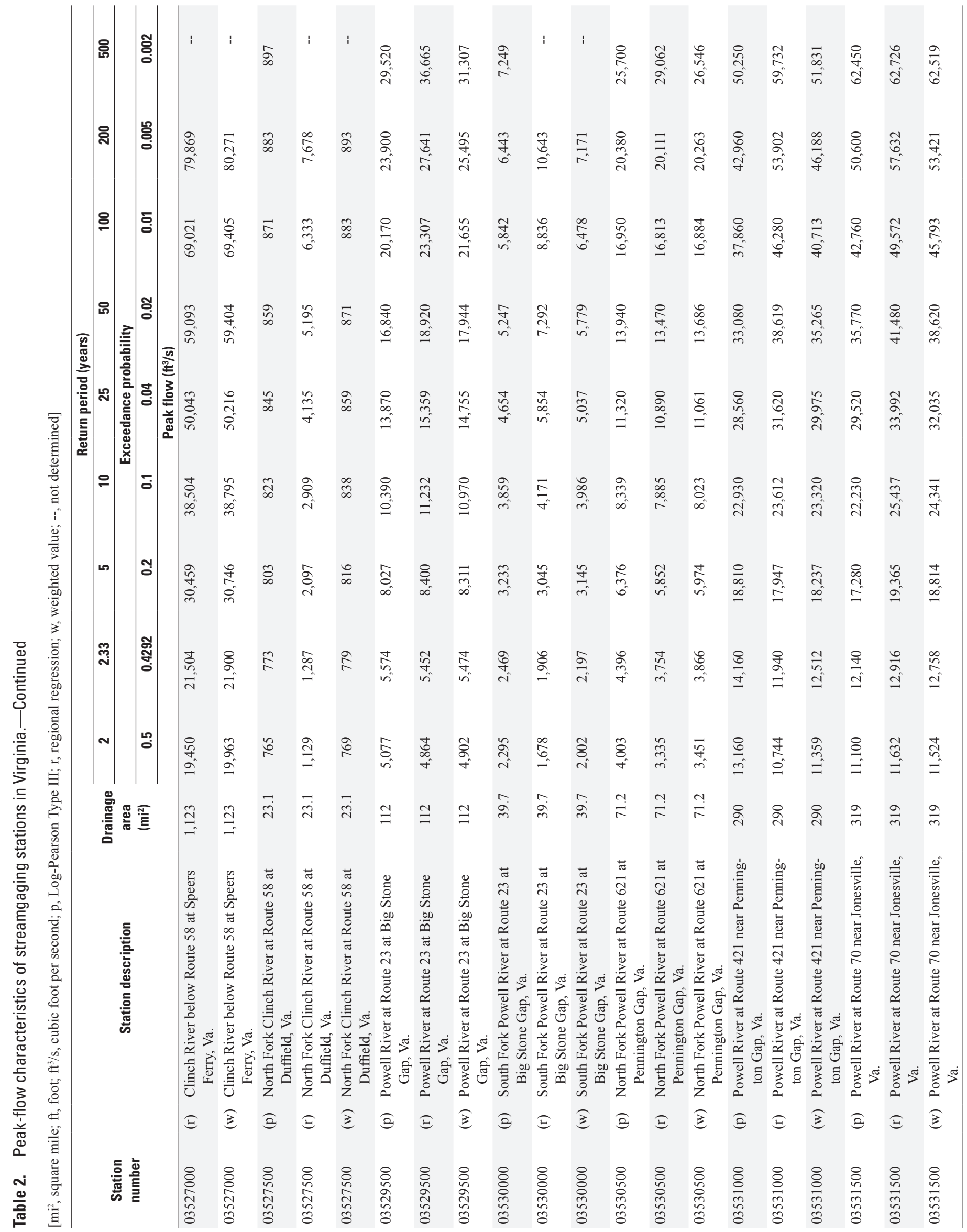


Manuscript approved on August 22, 2011.

\section{Prepared by:}

USGS Science Publishing Network

Raleigh Publishing Service Center

3916 Sunset Ridge Road

Raleigh, NC 27607

For additional information regarding this publication, contact:

Samuel H. Austin, Hydrologist

USGS Virginia Water Science Center

1730 East Parham Road

Richmond, Virginia 23228

phone: 804-261-2600

e-mail: saustin@usgs.gov

Or visit the Virginia Water Science Center Web site at: http://va.water.usgs.gov

A PDF version of this publication is available online at http://pubs.usgs.gov/sir/2011/5144/ 
